Report of Investigations 2016-2

\title{
TSUNAMI INUNDATION MAPS FOR YAKUTAT, ALASKA
}

E.N. Suleimani, D.J. Nicolsky, and R.D. Koehler

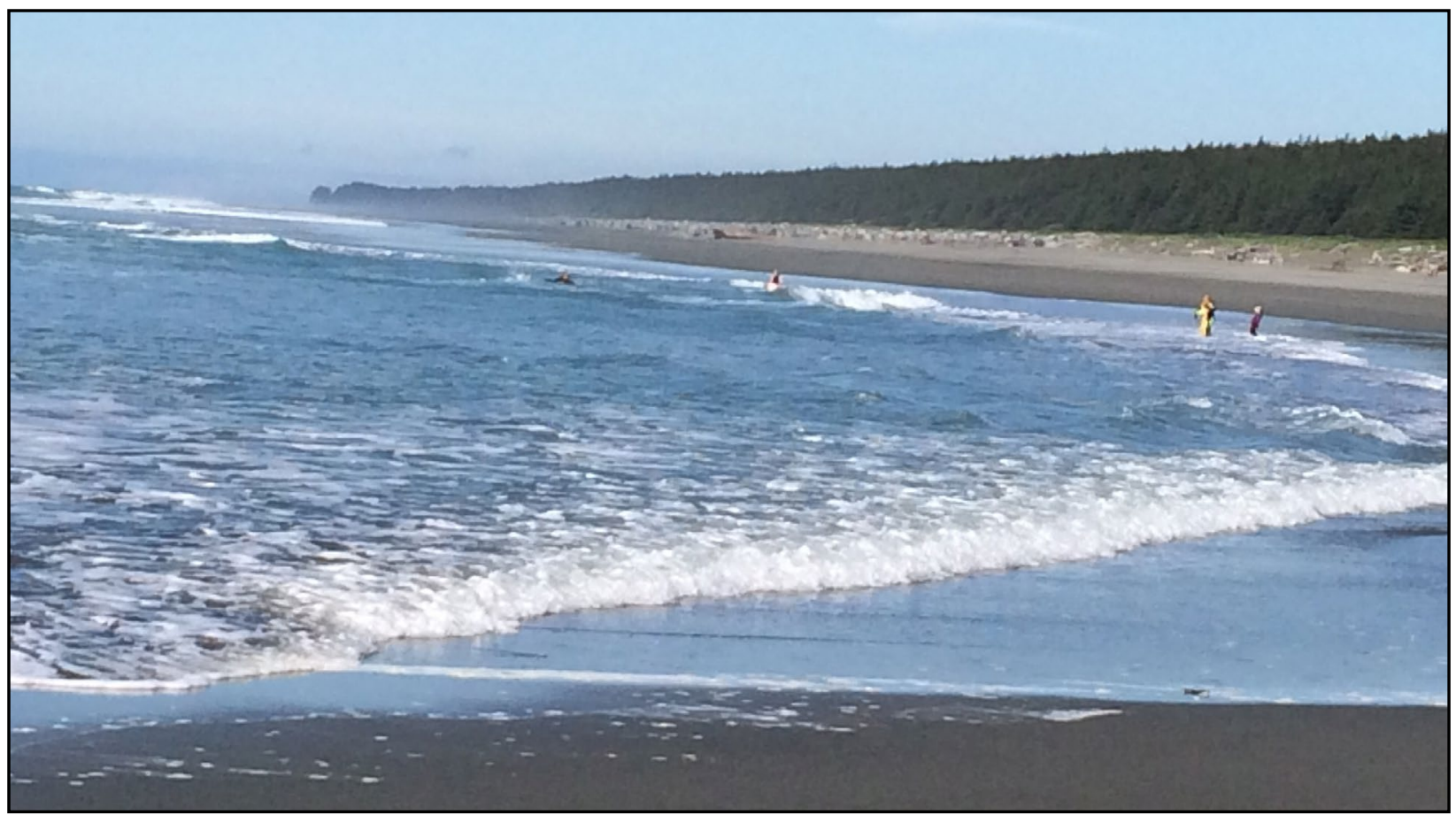

Yakutat residents enjoy surfing and playing in waves at Cannon Beach. Photo is looking to the northwest from Cannon Beach toward Ocean Cape. Photo by Jon Erickson, August 2014.

Published by

STATE OF ALASKA

DEPARTMENT OF NATURAL RESOURCES

DIVISION OF GEOLOGICAL \& GEOPHYSICAL SURVEYS

2016

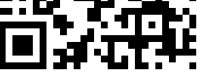




\section{TSUNAMI INUNDATION MAPS FOR YAKUTAT, ALASKA}

E.N. Suleimani, D.J. Nicolsky, and R.D. Koehler

Report of Investigations 2016-2

State of Alaska

Department of Natural Resources

Division of Geological \& Geophysical Surveys 


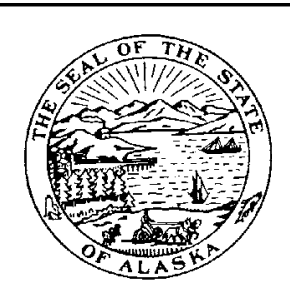

\section{STATE OF ALASKA}

Bill Walker, Governor

\section{DEPARTMENT OF NATURAL RESOURCES}

Marty Rutherford, Acting Commissioner

\section{DIVISION OF GEOLOGICAL \& GEOPHYSICAL SURVEYS}

Steve Masterman, State Geologist and Director

Publications produced by the Division of Geological \& Geophysical Surveys (DGGS) are available for free download from the DGGS website (www.dggs.alaska.gov). Publications on hard-copy or digital media can be examined or purchased in the Fairbanks office:

\section{Alaska Division of Geological \& Geophysical Surveys 3354 College Rd., Fairbanks, Alaska 99709-3707 \\ Phone: (907) 451-5020 Fax (907) 451-5050 \\ dggspubs@alaska.gov \\ www.dggs.alaska.gov}

Alaska State Library

State Office Building, 8th Floor 333 Willoughby Avenue

Juneau, Alaska 99811-0571

Elmer E. Rasmuson Library University of Alaska Fairbanks Fairbanks, Alaska 99775-1005
Alaska Resource Library \& Information Services (ARLIS)

3150 C Street, Suite 100

Anchorage, Alaska 99503-3982

University of Alaska Anchorage Library

3211 Providence Drive

Anchorage, Alaska 99508-4614 


\section{CONTENTS}

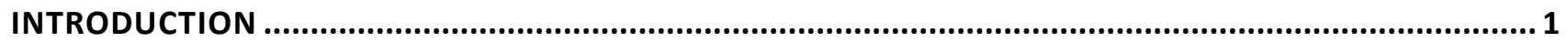

PROJECT BACKGROUND: REGIONAL AND HISTORICAL CONTEXT ...................................................

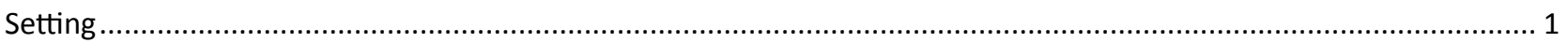

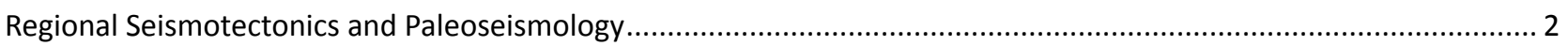

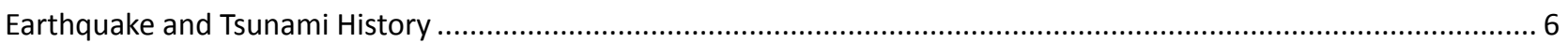

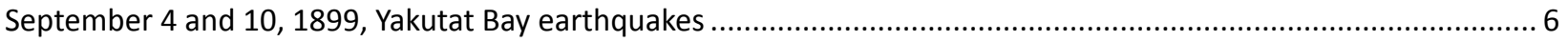

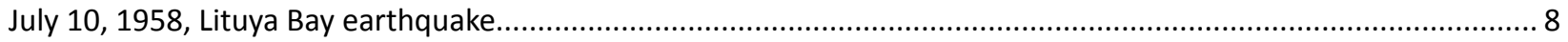

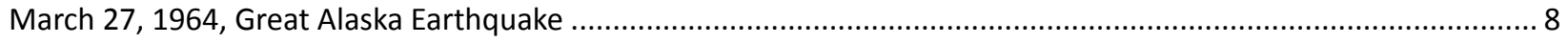

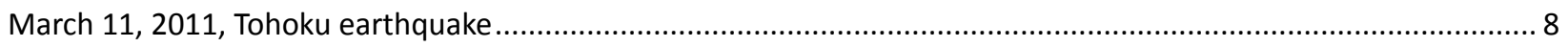

METHODOLOGY AND DATA

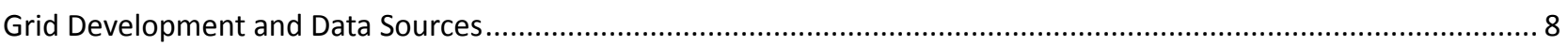

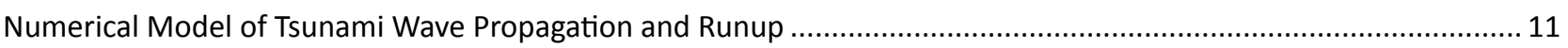

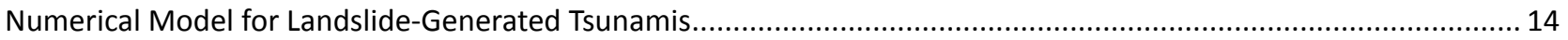

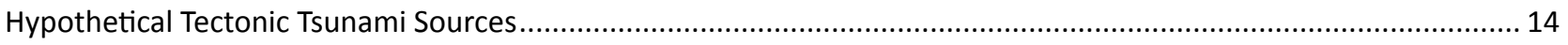

Source models of the multi-segment Great Alaska Earthquake ............................................................................ 19

Scenario 1. A $M_{W} 9.3$ multi-segment JDM event: The PWS, KP, and KI segments of the 1964 rupture, and

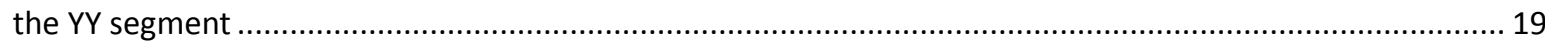

Scenario 2. A $M_{W} 9.3$ multi-segment SDM event: The PWS, KP, and KI segments of the 1964 rupture, and the

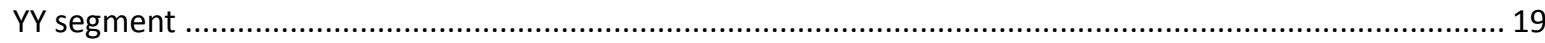

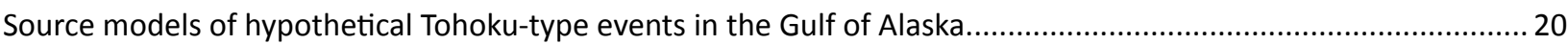

Scenario 3. A $M_{W} 9.2$ multi-segment event: The PWS, KP, and KI segments with Tohoku-type slip distribution.... 20

Scenario 4. A $M_{W} 9.2$ multi-segment event: The PWS, KP, KI, and YY segments with Tohoku-type slip

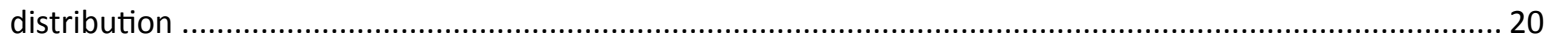

Scenario 5. A M $M_{W} 9.0$ multi-segment event in the Gulf of Alaska region: The PWS and KP segments with

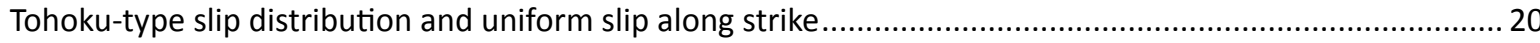

Scenario 6. A M $M_{W} 9.0$ multi-segment event in the Gulf of Alaska region: The PWS and KP segments with

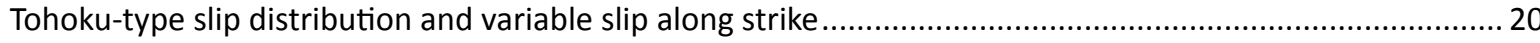

Source model of a hypothetical tsunamigenic earthquake in the Alaska Peninsula segment of the Alaska-

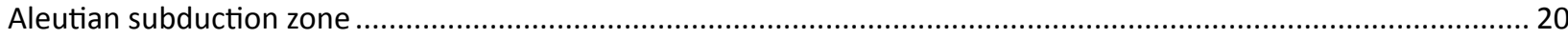

Scenario 7. A $M_{W} 9.0$ multi-segment event: The SH and SEM segments based on the SAFRR tsunami scenario... 20

Source models of hypothetical tsunamigenic earthquakes in the area of Yakutat Bay ............................................2 20

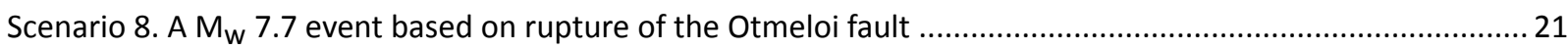

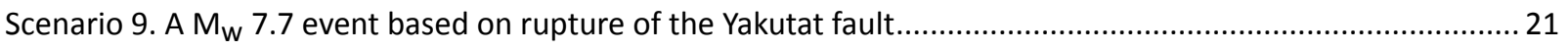

Scenario 10. A M 8.0 event based on a model of the 1899 Yakutat Bay earthquake ........................................ 22

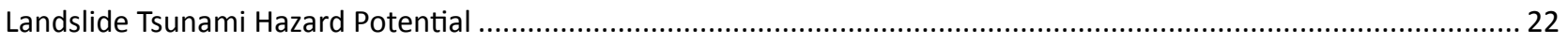

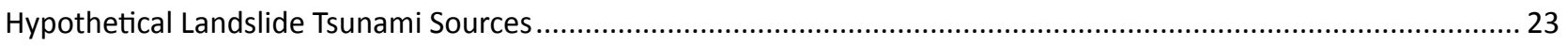

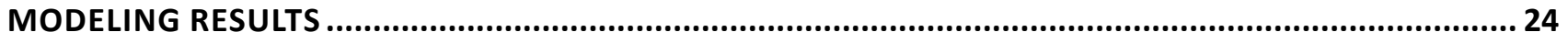

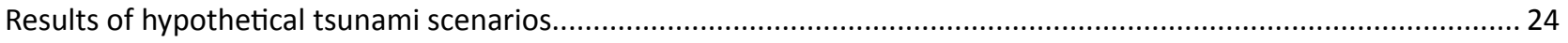

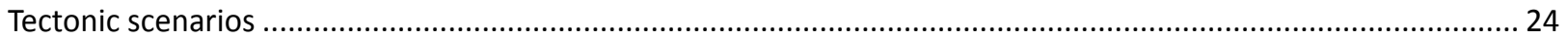

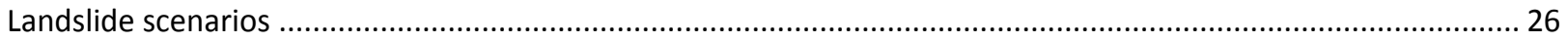

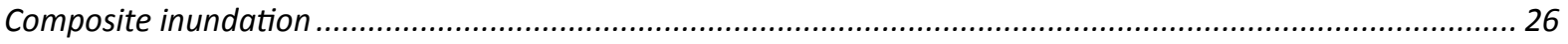

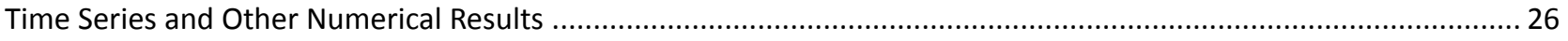

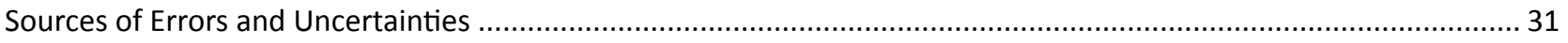

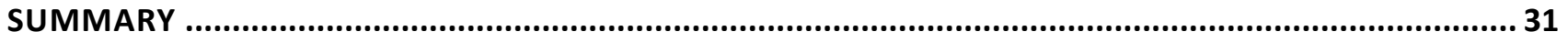

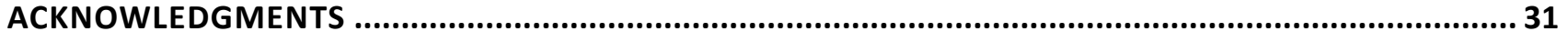

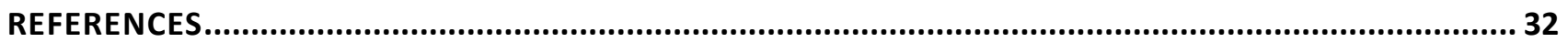




\section{FIGURES}

Figure 1. Map of south-central and southeastern Alaska, with rupture areas of the major earthquakes.....

2. Location of the community of Yakutat on Monti Bay, and the areas where underwater slides occurred during earthquakes of 1899, 1958, and 1964

3. Regional map of southern Alaska, showing the Yakutat block and major tectonic structures ....................... 4

4. Map of Yakutat Bay with major faults.

5. Vertical coseismic deformations for the source model of the 1964 Alaska tsunami, and recorded sea level at Yakutat compared with the time series calculated using this source function.

6. Nested bathymetry/topography grids for numerical modeling of tsunami propagation and runup................ 10

7. Extents of survey data, shoreline buffer regions, and locations of the GPS measurements in Yakutat........... 12

8. Vertical coseismic deformations for the source model of the 2011 Tohoku tsunami, and recorded sea level at Yakutat compared with the time series calculated using this source function .................................13

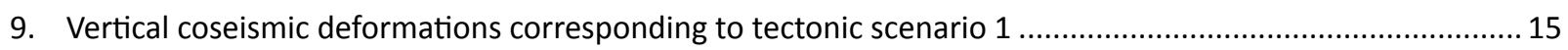

10. Map of Yakutat Bay, showing uplift and subsidence measurements........................................................21

11. Detailed map of Khantaak Island in Yakutat Bay, showing locations of observed underwater slides during

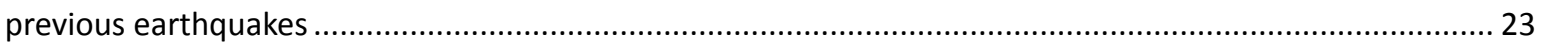

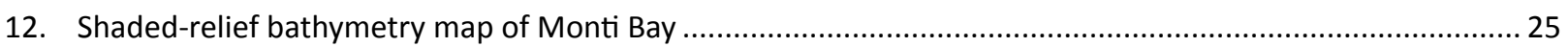

13. Maximum composite potential inundation extent for all tectonic scenarios, and maximum composite

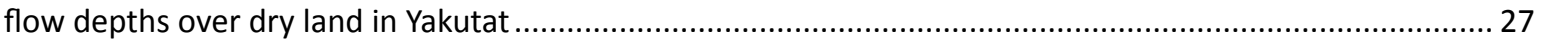

14. Maximum composite flow depths over dry land in Yakutat for landslide scenarios ....................................28

15. Generalized composite hazard map for landslide scenarios ...............................................................29

16. Projected composite flow depths over dry land in Yakutat for landslide scenarios .....................................30

\section{TABLES}

Table 1. Tsunami effects at Yakutat as summarized in Lander and in the NCEI tsunami database .............................. 7

2. Nested grids used to compute propagation of tsunami waves to the community of Yakutat......................... 9

3. Hypothetical tectonic scenarios used to model tsunami runup in Yakutat ................................................ 15

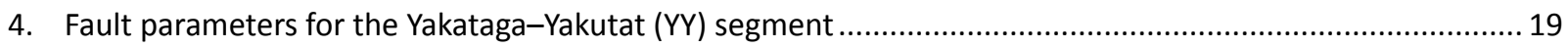

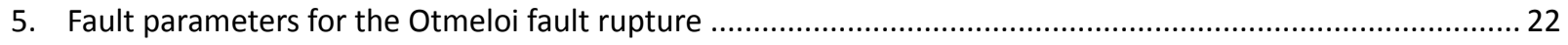

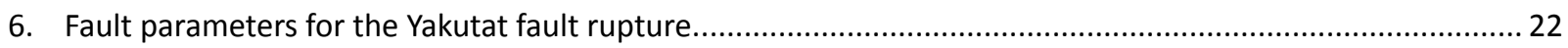

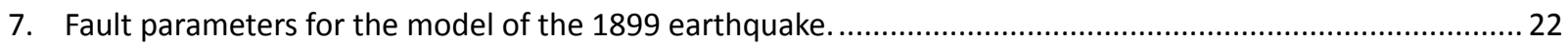

8. Hypothetical landslide scenarios used to model tsunami runup in Yakutat.................................................24

\section{APPENDIX}

APPENDIX A

Figure A-1. Locations of time series points in the Yakutat high-resolution grid ....................................................37

A-2. Time series of the water level and velocity at Yakutat for scenarios 1-5 at the locations shown

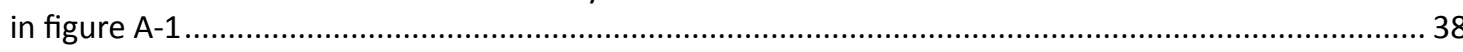

A-3. Time series of the water level and velocity at Yakutat for scenarios 6-10 at the locations shown

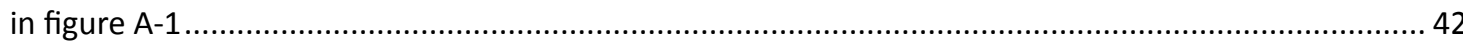

Table A-1. The longitude and latitude locations of the time series points......................................................... 46

A-2. Calculated maximum sea level for all tectonic scenarios at locations listed in table A-1 .......................46

A-3. Calculated maximum water current velocities for all tectonic scenarios at locations listed in table A-1..

\section{SHEET}

Maximum composite calculated extent of inundation for all scenarios, and the maximum composite flow depths over dry land in the Yakutat area 


\title{
TSUNAMI INUNDATION MAPS FOR YAKUTAT, ALASKA
}

\author{
E.N. Suleimani ${ }^{1}$, D.J. Nicolsky ${ }^{1}$, and R.D. Koehler ${ }^{2}$
}

\begin{abstract}
In this report we evaluate potential tsunami hazards for the southeastern Alaska community of Yakutat and numerically model the extent of inundation from tsunami waves generated by tectonic and landslide sources. We use numerical modeling of historical tsunami events at Yakutat, such as the tsunami triggered by the 1964 Great Alaska Earthquake, and the tsunami waves generated by the recent 2011 Tohoku earthquake, to verify the tsunami model. Potential hypothetical tsunami sources include variations of the extended 1964 rupture, megathrust earthquakes in the Prince William Sound and Alaska Peninsula regions, and earthquakes in the Yakataga-Yakutat area, including the historical September 10, 1899, earthquake. Local underwater landslide events in Monti Bay are also considered as possible tsunamigenic scenarios. Numerical modeling results, combined with historical observations in the region, are intended to provide guidance to local emergency management in tsunami hazard assessment, evacuation planning, and public education for the reduction of future tsunami hazard.
\end{abstract}

\section{INTRODUCTION}

Subduction of the Pacific plate under the North American plate has resulted in numerous great earthquakes and has the highest potential to generate tsunamis in Alaska (Dunbar and Weaver, 2008). Several historic tsunamis generated by earthquakes along the Alaska-Aleutian subduction zone (fig. 1) have resulted in widespread damage and loss of life in exposed coastal communities throughout the Pacific (Lander, 1996). Tsunamis originating in the vicinity of the Alaska Peninsula, Aleutian Islands, and the Gulf of Alaska are considered to be a near-field hazard for Alaska, and can reach Alaska's coastal communities within minutes of an earthquake. Reducing property damage and loss of life is highly dependent on how well a community is prepared. Thus, estimating the potential flooding of the coastal zone in the event of a local or distant tsunami is an essential component of the preparedness process.

On March 27, 1964, the largest earthquake ever recorded in North America struck south-central Alaska. This $\mathrm{M}_{\mathrm{W}} 9.2$ megathrust earthquake (fig. 1) generated the most destructive tsunami in Alaska history and, farther south, impacted the west coasts of the United States and Canada (Plafker and others, 1969; Kanamori, 1970; Johnson and others, 1996; Lander, 1996). In addition to the major tectonic tsunami, which was generated by an ocean-floor displacement between the trench and the coastline, more than 20 local tsunamis were generated by landslides in coastal Alaska (Lander, 1996). They arrived almost immediately after shaking was felt, leaving no time for warning or evacuation. Of the 131 fatalities associated with this earthquake, 122 were caused by tsunami waves (Lander, 1996). During the 1964 earthquake, local tsunamis caused most of the damage and accounted for 76 percent of tsunami fatalities in Alaska (Haeussler and others, 2007; Ryan and others, 2010; Suleimani and others, 2009, 2011).

The production of tsunami evacuation maps for a community consists of several steps. First, we develop credible hypothetical tsunami scenarios on the basis of relevant local and distant sources and tsunami generation mechanisms. We characterize tsunami sources using the level of detail necessary to describe the essential characteristics of the wave, with local tsunami sources having more detailed characterization. Next, we perform model simulations for each of these scenarios. The results are then compared with historical tsunami observations, if such data exist. Finally, we develop a "worst case" inundation line that encompasses the maximum extent of flooding based on model simulation of all source scenarios and historical observations. The "worst case" inundation line becomes a basis for local tsunami hazard planning and for developing evacuation maps.

The tsunami inundation maps of Yakutat described in this report represent the results of the continuous combined effort of state and federal agencies to produce inundation maps for many Alaska coastal communities. In this report, we generally provide both metric and imperial units of measure. When we quote existing data, we report the data in the original units without conversion.

\section{PROJECT BACKGROUND: REGIONAL AND HISTORICAL CONTEXT}

\section{SETTING}

The community of Yakutat (59 32'59" N, 139 44'48” W), population 631, is isolated among the lowlands along the Gulf of Alaska, $362 \mathrm{~km}(225 \mathrm{mi})$ northwest of Juneau (fig. 1). It is at the mouth of Yakutat Bay, one of the few refuges for vessels along this stretch of the coast (fig. 2). It is surrounded by the Tongass National Forest, Wrangell-St. Elias National Park and Preserve, and Glacier Bay National Park and Preserve. The following information is extracted from the Alaska Community Database maintained by the State of Alaska Division of Community and Regional Affairs (DCCED/DCRA, 2013; https://www.commerce.alaska.gov/web/dcra/).

Yakutat has a diverse cultural history. The original settlers are believed to have been Native Eyak-speaking people later conquered by the Tlingits. Yakutat means "the place where

\footnotetext{
${ }^{1}$ Alaska Earthquake Center, Geophysical Institute, University of Alaska, P.O. Box 757320, Fairbanks, AK 99775-7320; ensuleimani@alaska.edu

${ }^{2}$ Alaska Division of Geological \& Geophysical Surveys, 3354 College Rd., Fairbanks, AK 99709-3707; now at Nevada Bureau of Mines and Geology, Mackay School of Earth Science and Engineering, University of Nevada, Reno, 1664 North Virginia Street, MS 178, Reno, NV 89557
} 


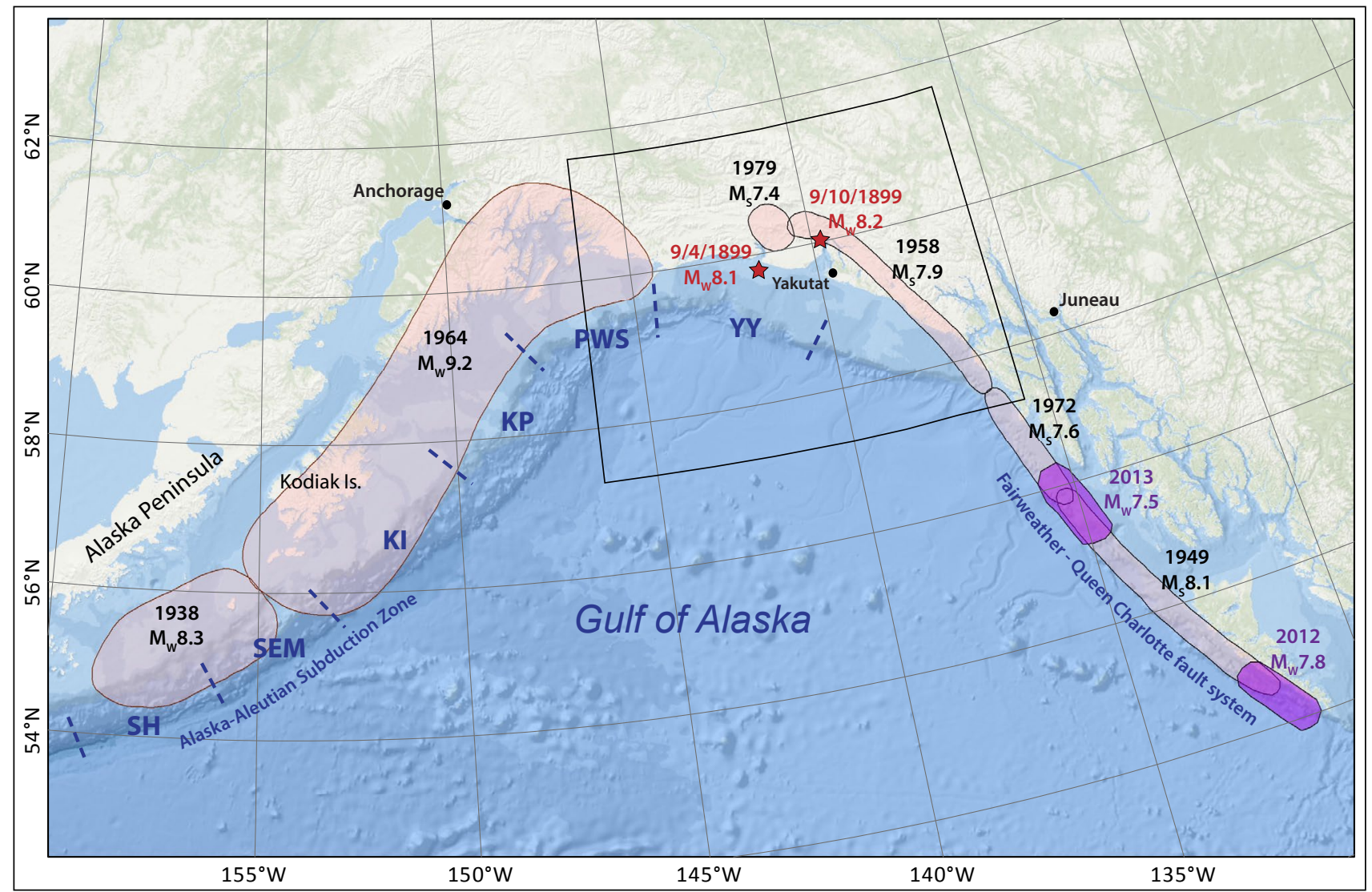

Figure 1. Map of south-central and southeastern Alaska, with rupture areas and dates of the major earthquakes. Red stars indicate epicenters of two September 1899 earthquakes. The segment notations of the Alaska-Aleutian megathrust are from Nishenko and Jacob (1990): the Yakataga-Yakutat (YY), Prince William Sound (PWS), Kenai Peninsula (KP), Kodiak Island (KI), Semidi Islands (SEM), and Shumagin Islands (SH) segments. The area inside the black polygon is shown in detail in figure 3.

the canoes rest." During the 18th and 19th centuries, English, French, Spanish, and Russian explorers came to the region. The Russian-American Company built a fort here in 1805 to harvest sea otter pelts, but because the company would not allow Tlingits access to traditional fisheries, a Tlingit war party attacked and destroyed the post. In 1884 the Alaska Commercial Company opened a store in Yakutat, and by 1886 the black sand beaches were being mined for gold. In 1889 the Swedish Free Mission Church opened a school and sawmill in the area. A cannery, sawmill, store, and railroad were constructed in 1903. Most residents moved to the current Yakutat site to be closer to the cannery, which operated through 1970. During World War II, a large aviation garrison and paved runway were constructed; the runway is still in use today. The City of Yakutat was formed in 1948, but in 1992 the city was dissolved and a borough was organized for the region. Today, the area maintains a traditional Tlingit culture with influences from the original Eyak Athabascans, as well as Russian, English, and American traders and miners. Fishing and subsistence activities are prevalent.

Yakutat has no road access. The airport has daily commercial jet service, and air taxi and float plane services are

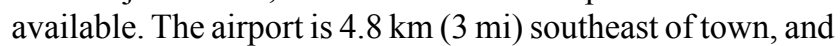
there is a seaplane base $1.6 \mathrm{~km}(1 \mathrm{mi})$ northwest of town. The U.S. Forest Service owns five airstrips in the vicinity, and the National Park Service operates an airstrip at East Alsek River. The borough operates the state-owned boat harbor and the Ocean Cape Dock. The Alaska Marine Highway System ferry provides service to Yakutat. Yakutat's Monti Bay is the only sheltered, natural deep-water port in the Gulf of Alaska (fig. 2). Barges deliver goods monthly during the winter and more frequently in summer.

\section{REGIONAL SEISMOTECTONICS AND PALEOSEISMOLOGY}

The primary tectonic elements of the Pacific-North American plate boundary in southern Alaska are the Alaska-Aleutian subduction zone and the $>1,000-\mathrm{km}$-long (>620-mi-long) Fairweather-Queen Charlotte (FW-QC) fault system (fig. 1). In the Gulf of Alaska, the Pacific plate subducts beneath the North American plate along the Aleutian trench to the west, and translates along the FW-QC fault system on the east (Worthington and others, 2008). The oblique collision and flat-slab subduction of the Yakutat block, which is sandwiched between the Pacific and North American plates (fig. 3), has resulted in the St. Elias orogen, the highest coastal mountain range on Earth, located along the Gulf of Alaska coast from about $146^{\circ} \mathrm{W}$ to $140^{\circ} \mathrm{W}$ (Pavlis and others, 2004). In the Yakutat area, the continuation of the FW-QC fault system includes the Boundary fault (BF) 


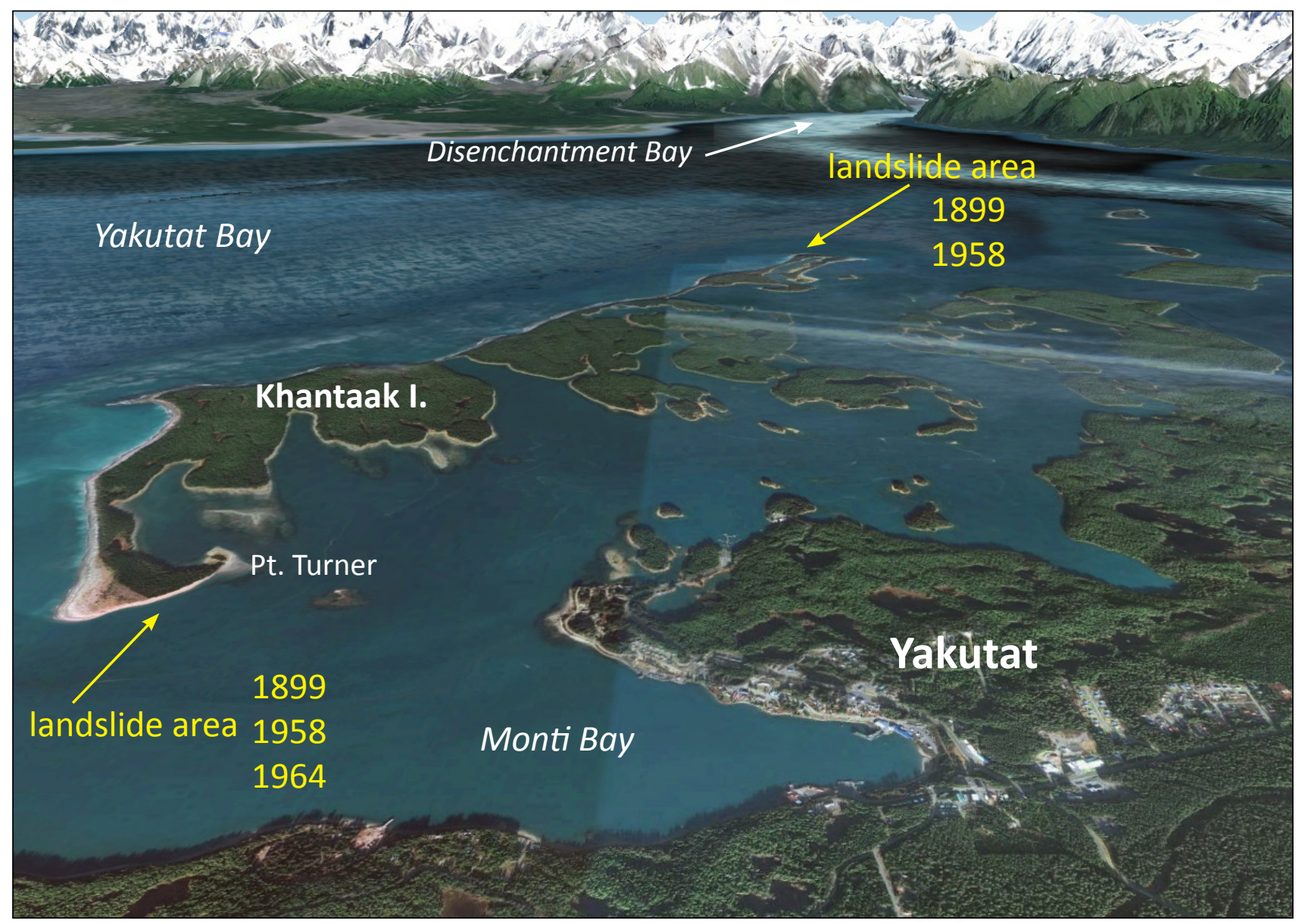

Figure 2. Location of the community of Yakutat on Monti Bay, and the areas where underwater slides occurred during earthquakes of 1899, 1958, and 1964.

and the Chaix Hills fault (CHF) (fig. 3). The primary tectonic elements of the Yakutat-North American plate boundary include the Chugach-St. Elias (CSE) fold-and-thrust belt, the offshore Transition fault (TF), and the offshore Pamplona Zone (PZ) fold-and-thrust belt with its onshore extensions, including the Malaspina (MF), Esker Creek, and Bancas Point faults (figs. 3 and 4).

In southeastern Alaska, plate motion is accommodated along the Fairweather fault, a transform fault that extends primarily offshore along the entire southeastern Alaska coastline, becoming the Queen Charlotte fault to the south in British Columbia (figs. 1 and 3). Fletcher and Freymueller (2003) estimate a slip rate of $\sim 44.6 \pm 2.0 \mathrm{~mm} / \mathrm{yr}(\sim 1.8 \pm 0.08$ in/yr) for the northern Fairweather fault, one of the highest rates observed across any strike-slip fault in the world. The entire Fairweather-Queen Charlotte fault system has ruptured in large strike-slip earthquakes over the last century: 1927 $\left(\mathrm{M}_{\mathrm{S}} 7.1\right), 1949\left(\mathrm{M}_{\mathrm{S}} 8.1\right), 1958\left(\mathrm{M}_{\mathrm{S}} 7.9\right)$, and $1972\left(\mathrm{M}_{\mathrm{S}} 7.6\right)$ (Sykes, 1971; Page, 1973; Tocher, 1960). The 1958 event, known as the "Lituya Bay earthquake", triggered a large landslide into Lituya Bay (fig. 3) that generated a 530-m-high (1,740-ft-high) wave (Miller, 1960). These events indicate that seismic slip along the $\mathrm{FW}-\mathrm{QC}$ fault system is parallel to the direction of motion between the North American and the Pacific plates (Doser and Lomas, 2000). Most of the modern seismic events along the Fairweather fault in this area are larger magnitude aftershocks of these historic sequences. Fletcher and Freymueller (2003) estimate that only 75 years would be required to build up slip equivalent to the 1958 $\mathrm{M}_{\mathrm{s}} 7.9$ earthquake along the northern Fairweather fault, and Nishenko and Jacob (1990) have estimated a recurrence interval of 120 to 130 years for earthquakes similar to the $1972 M_{\mathrm{S}}$ 7.6 Sitka and $1949 \mathrm{M}_{\mathrm{S}} 8.1$ Queen Charlotte earthquakes, respectively.

The most recent events that occurred along the FW-QC transform boundary were the 27 October $2012 \mathrm{M}_{\mathrm{W}} 7.8$ Haida Gwaii thrust earthquake and the 5 January $2013 \mathrm{M}_{\mathrm{W}} 7.5$ Craig strike-slip earthquake (fig. 1). The 2012 Haida Gwaii event occurred along the highly oblique convergent Queen Charlotte margin, indicating slip partitioning in this area into thrust and strike-slip motion (James and others, 2015; Haeussler and others, 2015). This earthquake generated tsunami waves exceeding $6 \mathrm{~m}(20 \mathrm{ft})$ in local runup at a number of sites, and measuring $0.8 \mathrm{~m}(2.6 \mathrm{ft}$ ) on a tide gauge in Hawaii (Leonard and Bednarski, 2015). The 2013 Craig earthquake occurred in the gap between the main part of the rupture of the 1949 earthquake and the 1972 Sitka earthquake (James and others, 2015). It ruptured a section of the Queen Charlotte fault separated by about $200 \mathrm{~km}$ (124 mi) from the Haida Gwaii aftershocks, and was characterized by right-lateral strike-slip motion (Holtkamp and Ruppert, 2015). 


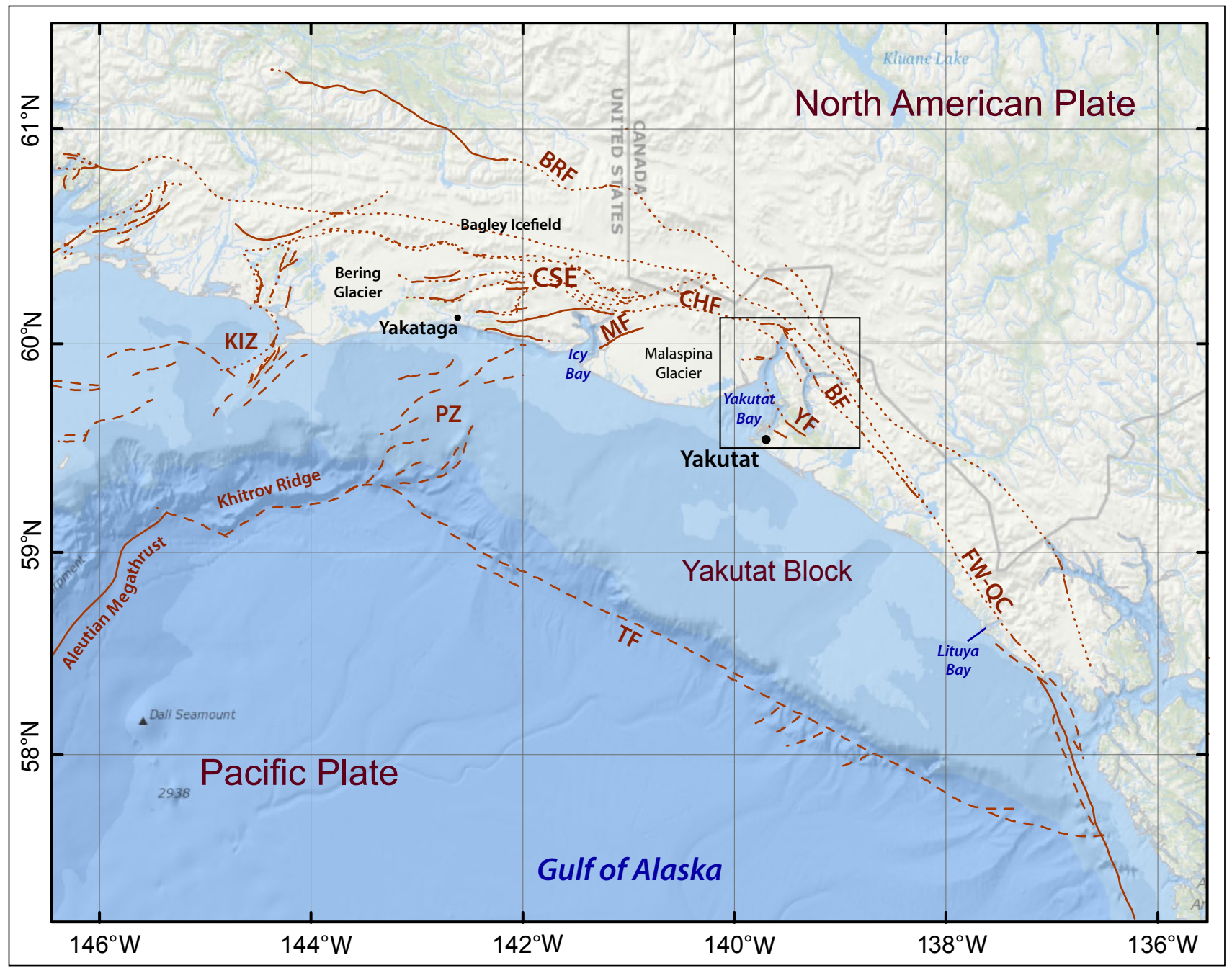

Figure 3. Regional map of southern Alaska, showing the Yakutat block and major tectonic structures from Koehler (2013). KIZ = Kayak Island zone, $P Z=$ Pamplona zone, $C S E=$ Chugach-St. Elias fault system, BRF = Border Ranges fault, MF = Malaspina fault, $C H F=C h a i x$ Hills fault, $B F=$ Boundary fault, YF = Yakutat fault, FW-QC = Fairweather-Queen Charlotte fault, TF = Transition fault. The area inside the black rectangle is shown in detail in figure 4.

The Alaska-Aleutian arc is one of the most seismically active regions in the world and has experienced some of the greatest events in recorded history. Almost the entire arc ruptured in a series of $M_{W}$ 7.4-9.2 tsunamigenic events starting with the $\mathrm{M}_{\mathrm{W}} 8.3$ earthquake near Kodiak Island in 1938 and culminating with the $\mathrm{M}_{\mathrm{W}} 8.7$ Rat Island earthquake in 1965. The $M_{W} 9.21964$ Great Alaska Earthquake ruptured a region from Prince William Sound to Kodiak Island and generated one of the most destructive tectonic tsunamis in Alaska's history. At the eastern part of the megathrust, two great earthquakes occurred in 1899 in the Yakutat block (September 4, 1899, Yakataga and September 10, 1899, Yakutat Bay) (figs. 1 and 3), which lies offshore southern Alaska in the Gulf of Alaska and converges with and subducts beneath North America (Worthington and others, 2012).

For the purpose of constructing tsunami source scenarios that span from south-central Alaska to the eastern Aleutians, we follow the terminology of Nishenko and Jacob (1990) for the segments of the megathrust that have been repeatedly ruptured by large and great earthquakes, or for gaps between the rupture segments: Yakataga-Yakutat (YY), Prince William Sound (PWS), Kenai Peninsula (KP), Kodiak Island (KI), Semidi Islands (SEM), and Shumagin Islands (SH) (fig. 1). Using seismic waveform data, Christensen and Beck (1994) showed that there were two areas of high moment release during the 1964 Great Alaska Earthquake, representing the two major asperities of the 1964 rupture zone: the Prince William Sound asperity with an average slip of $18 \mathrm{~m}(59 \mathrm{ft})$, and the Kodiak asperity with an average slip of $10 \mathrm{~m}(33 \mathrm{ft})$. Subsequent studies have shown that the Prince William Sound asperity is on the Yakutat-North American megathrust whereas the Kodiak asperity is on the Pacific-North American megathrust (Ferris and others, 2003; Eberhart-Phillips and others, 2006; Worthington and others, 2010, 2012; Gulick and others, 2013). Analysis of historical earthquake data in the PWS and KI segments (Nishenko and Jacob, 1990) showed that the KI segment produced significant megathrust earthquakes more frequently and also independently of the PWS segment. Paleoseismic data also show that the KI segment ruptured independently in a 


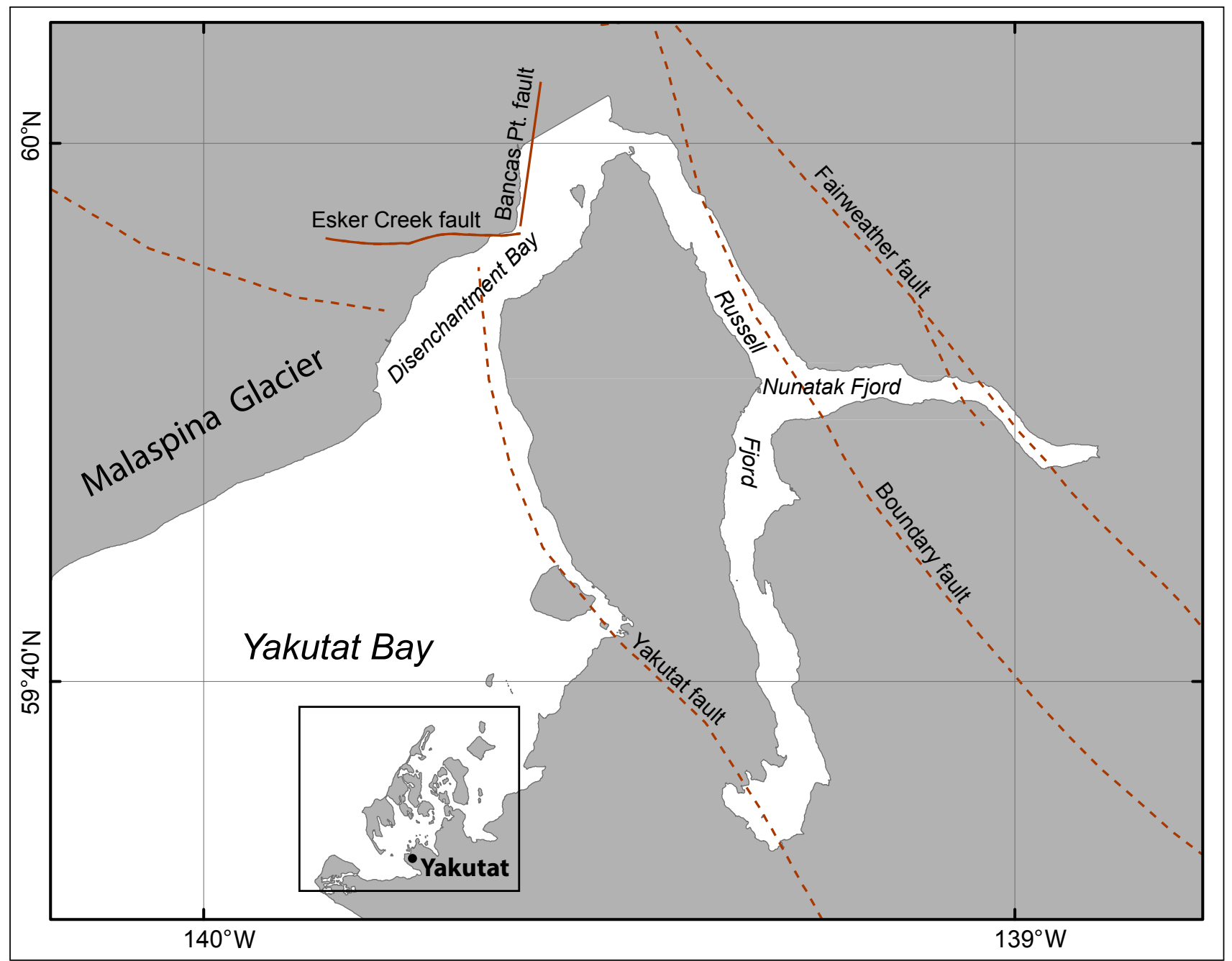

Figure 4. Map of Yakutat Bay with major faults (from Pavlis and others, 2012). Black rectangle outlines the high-resolution grid of Yakutat, for which tsunami inundation was calculated.

large earthquake about 500 years ago, about 360 years more recently than the penultimate great earthquake that ruptured both the KI and PWS segments (Carver and Plafker, 2008). The results of joint inversion of tsunami and geodetic data from the 1964 earthquake (Johnson and others, 1996) also suggest two areas of high moment release. The PWS and KI segments have different recurrence intervals, with estimates of the recurrence interval for $\mathrm{M}_{\mathrm{S}} 7.5-8$ earthquakes in the KI segment being as low as 60 years (Nishenko, 1991). On the basis of all published paleoseismic data for the region Carver and Plafker (2008) calculate that the median intervals between the past eight great earthquakes $\mathrm{M}_{\mathrm{W}}>8$ in the PWS segment of the eastern Aleutian seismic zone range from 333 to 875 years, with an average of 589 years. Shennan and others (2014) analyzed new paleoseismic field data from three sites in the PWS segment and revised the recurrence intervals of great earthquakes in the PWS segment. Their results suggest that the intervals range from $\sim 420$ to $\sim 610$ years with a mean of $\sim 535$ years, excluding the interval between the 1964 earthquake and the penultimate event, which is $\sim 883$ years.

In a paleoseismic study of regional land subsidence at Kenai Peninsula sites, Hamilton and Shennan (2005) estimated coseismic subsidence during the 1964 earthquake and two earlier events. They showed that the earthquake dated to $1,500-1,400$ years BP produced more than twice the subsidence caused by the 1964 earthquake. By comparing the Kenai Peninsula sites with other sites around Cook Inlet, the authors found that each of the three great earthquakes in the study had a different pattern of coseismic subsidence. Recent work by Shennan and others (2009) tests the hypothesis that in some seismic cycles, megathrust segments can, as proposed in the segmentation model by Nishenko and Jacob (1990), rupture simultaneously to produce earthquakes greater than historical events. Shennan and others (2008) present geologic evidence of six prehistoric major tsunamigenic earthquakes in the Kenai Peninsula area of south-central Alaska in the past 4,000 years based on radiocarbon ages of tidal marsh deposits in Girdwood. Their paper presents paleoseismic evidence that earthquakes approximately 900 and 1,500 years BP simultaneously ruptured three adjacent segments of the Aleutian Megathrust: the PWS, KI, and YY segments. The rupture area of these earthquakes was estimated to be 23,000 $\mathrm{km}^{2}\left(8,880 \mathrm{mi}^{2}\right)$ greater than that of the $\mathrm{M}_{\mathrm{W}} 9.2$ Great Alaska Earthquake of 1964, and with a 15 percent larger seismic 
moment. We use these findings to develop several hypothetical tsunamigenic earthquake models described in the section "Hypothetical tectonic tsunami sources."

The Yakataga-Yakutat area is at the eastern end of the megathrust, where the strongest tectonic influence results from the collision of the Yakutat block with southern Alaska (fig. 3). Elliott and others $(2010,2013)$ proposed a regional tectonic model for the St. Elias orogen based on GPS measurements of the surface deformation. Based on analyses of the GPS data, Elliott and others $(2010,2013)$ subdivided the region into three blocks (Elias, Icy Bay, and Yakutat) separated by four fault systems (or fault zones): the Malaspina-Pamplona system, the Yakataga-Chaix Hills system, the Foreland fault zone, and the décollement between the Yakutat block and the upper plate. The onshore faults used in the study were characterized by Chapman and others $(2008,2012)$ and Pavlis and others $(2012)$. The offshore fault zones were published by Gulick and others $(2007,2013)$ and Worthington and others $(2008,2012)$. Worthington and others estimated $\sim 37 \mathrm{~mm} / \mathrm{yr}$ (1.46 in/year) of convergence across the St. Elias orogen (fig. 3).

Plafker and Thatcher (2008) re-evaluated the mechanisms of the two great Yakutat Bay earthquakes of September 1899 (fig. 1) and showed that coseismic deformation was caused by onshore uplift. It was proposed that the September 4 event ruptured the onshore area in the Chugach-St. Elias (CSE) region, that involved displacement on one or more of the onshore Late Cenozoic thrust faults east of Yakataga (fig. 3), while the September 10 earthquake is thought to have ruptured the mostly onshore Bancas Point and Esker Creek faults (fig. 4). This explains the absence of a tsunami in the Gulf of Alaska. However, Plafker and Thatcher (2008) write about violent waves observed in Yakutat Bay during the September 10 earthquake that were probably caused in part by large coseismic uplift of shores in Disenchantment Bay, by calving of the front of Hubbard Glacier, and/or by underwater slides along large delta fronts. Plafker and Thatcher (2008) concluded that the 1899 earthquake sequence most likely did not rupture through the offshore portion of the Yakataga seismic gap, a region between the 1964 rupture area and the focal area of the 1899 earthquakes. This finding suggests that the YY segment has a high potential for a future tsunamigenic earthquake, which is consistent with seismic and tsunami hazard predictions by Shennan and others $(2009,2014)$.

We consider numerous tectonic tsunami sources for construction of tsunami hazard maps for Yakutat and develop hypothetical scenarios that are consistent with the regional seismotectonics and paleoseismology. Taking into account the directional properties of a tsunami source and previous studies of the far-field effects of the 1964 tsunami (Myers and Baptista, 2001; Suleimani, 2011), we conclude that the section of the Alaskan-Aleutian subduction zone that includes Kodiak Island, the Kenai Peninsula, Prince William Sound, and the Yakutat block is the area best positioned to generate a tsunami wave that could significantly affect the Yakutat region. We develop scenarios based on various combinations of these rupture sections. Additionally, we develop scenarios in the Yakataga-Yakutat area that are based on ruptures of local inferred faults that cross Yakutat Bay.

\section{EARTHQUAKE AND TSUNAMI HISTORY}

Yakutat's location on the Gulf of Alaska coast exposes it to tsunami waves coming from multiple directions. The impact of a tsunami event at Yakutat could potentially be magnified by the remoteness and inaccessibility of the community. There is concern over potential losses to the local fishing industry and infrastructure, which is located mainly along the low-lying coastal plain. Table 1 provides the summary of tsunami effects at Yakutat caused by earthquakes of the last century, as summarized by Lander (1996), and recent trans-Pacific and local tsunami records extracted from the tsunami database of the National Center for Environmental Information (NCEI; https://www.ncei.noaa.gov/). We describe below four events that had significant effects on Yakutat. The following accounts of the earthquake and tsunami observations are from Yehle (1979), unless otherwise noted. Figure 2 gives a general view of the Yakutat Bay area and illustrates locations of landslides triggered by these earthquakes.

\section{September 4 and 10, 1899, Yakutat Bay earthquakes}

In September 1899, three earthquakes were strongly felt in Yakutat: the $M_{W} 8.1$ event on September 4, and two earthquakes on September 10, the second of which had a magnitude of $M_{W} 8.2$ (Plafker and Thatcher, 2008). Strong ground motion caused by the September 4 earthquake lasted about 2-5 minutes, causing violent rocking and shaking of buildings. Shaking from the first earthquake of September 10 lasted about 3 seconds, while the second earthquake that day was the most severe event of the series, probably causing most of the effects that were later summarized by Tarr and Martin (1912). They reported the largest uplifts in land ranged from $30 \mathrm{ft}(9.1 \mathrm{~m})$ to about $47.5 \mathrm{ft}(14.5 \mathrm{~m})$ on the west coast of Disenchantment Bay (fig. 2). A detailed analysis of the coseismic shoreline displacements that occurred in the Yakutat Bay area in 1899 is also provided in Plafker and Thatcher (2008). According to Tarr and Martin (1912) there were two large submarine landslides - one along the south end of Khantaak Island, and the other at the northern end of the island (fig. 2). During the earthquake, high waves and great changes in water level were observed in Monti Bay, including three large waves at intervals of about 5 minutes. The waves washed out some houses located about 2-3 m (6.5-9.8 ft) above present high tide. The total change in water level in Monti Bay was about $5 \mathrm{~m}(16.4 \mathrm{ft})$. According to Lander (1996), “...the schooner Crystal, lying in the mud, rocked from side to side, and the bay was full of whirlpools, spinning trees, lumber, and driftwood moving around so fast that the eye could hardly follow; the water churned into a seething mass."

Plafker and Thatcher (2008) concluded that the total extent of the 1899 rupture remains poorly resolved. They suggested four distinct regions within which the 1899 slip could have occurred, with locally large slip in the vicinity of Yakutat Bay possibly extending west as far as Yakataga (fig. 3 and plate 7 in Plafker and Thatcher, 2008). 
Table 1. Tsunami effects at Yakutat as summarized in Lander (1996), and in the NCEI tsunami database (National Geophysical Data Center/World Data Service [NGDC/WDS]: Global Historical Tsunami Database, 2015). Cause of tsunami: L=landslide, $E Q=e$ arthquake.

\begin{tabular}{|c|c|c|c|c|c|c|}
\hline Date & Cause & Ms & Origin & $\begin{array}{l}\text { Location of } \\
\text { Effects }\end{array}$ & $\begin{array}{l}\text { Max. } \\
\text { water } \\
\text { height } \\
(\mathrm{m})\end{array}$ & Comments $^{\mathrm{a}}$ \\
\hline $1845-1847$ & $\mathrm{~L}$ & & Alaska & Yakutat Bay & & $\begin{array}{l}\text { "100" Natives perished near } \\
\text { Haenke Island. Date uncertain. }\end{array}$ \\
\hline $9 / 4 / 1899$ & EQ & 8.2 & $\begin{array}{l}\text { Cape Yakataga, } \\
\text { Alaska }\end{array}$ & Yakutat & 3.1 & $\begin{array}{l}\text { Water ran out of bay below lowest } \\
\text { tide and returned as swell, flooding } \\
\text { an Indian village. }\end{array}$ \\
\hline $9 / 10 / 1899$ & $E Q+L$ & 8.6 & $\begin{array}{l}\text { Southeastern } \\
\text { Alaska }\end{array}$ & Yakutat & 4.6 & Whirlpools formed \\
\hline $9 / 10 / 1899$ & $E Q+L$ & 8.6 & $\begin{array}{l}\text { Southeastern } \\
\text { Alaska }\end{array}$ & $\begin{array}{l}\text { Western shore } \\
\text { of Yakutat Bay }\end{array}$ & 9 & $\begin{array}{l}\text { Water inundated } 0.5 \mathrm{~km}(0.3 \mathrm{mi}) \\
\text { inland }\end{array}$ \\
\hline $9 / 10 / 1899$ & $E Q+L$ & 8.6 & $\begin{array}{l}\text { Southeastern } \\
\text { Alaska }\end{array}$ & Yakutat Bay & 3 & $\begin{array}{l}\text { Sawmill damaged, huts flooded. } \\
\text { Part of Khantaak Island slid into the } \\
\text { bay. }\end{array}$ \\
\hline $4 / 1 / 1946$ & EQ & 7.3 & $\begin{array}{l}\text { Eastern Aleutian } \\
\text { Islands, Alaska }\end{array}$ & Yakutat & 0.37 & Uplift occurred \\
\hline $11 / 4 / 1952$ & EQ & 8.2 & $\begin{array}{l}\text { Kamchatka } \\
\text { Peninsula, Russia }\end{array}$ & Yakutat & 0.2 & No comments \\
\hline $3 / 9 / 1957$ & EQ & 8.3 & $\begin{array}{l}\text { Central Aleutian } \\
\text { Islands, Alaska }\end{array}$ & Yakutat Bay & 0.34 & No comments \\
\hline $7 / 10 / 1958$ & $\mathrm{~L}$ & 7.9 & $\begin{array}{l}\text { Southeastern } \\
\text { Alaska }\end{array}$ & Yakutat & 0.9 & Mooring lines torn loose \\
\hline $7 / 10 / 1958$ & $\mathrm{~L}$ & 7.9 & $\begin{array}{l}\text { Southeastern } \\
\text { Alaska }\end{array}$ & Yakutat Bay & 6.1 & $\begin{array}{l}\text { Slumping of land on Khantaak } \\
\text { Island, } 3 \text { deaths }\end{array}$ \\
\hline $5 / 22 / 1960$ & EQ & 8.6 & Chile & Yakutat & 0.76 & No comments \\
\hline $3 / 28 / 1964$ & $E Q+L$ & 8.5 & Gulf of Alaska & Yakutat Bay & 1.5 & No comments \\
\hline $11 / 29 / 1975$ & $E Q$ & 7.2 & Hawaii & Yakutat & 0.05 & No comments \\
\hline $2 / 28 / 1979$ & $E Q+L$ & 7.1 & Gulf of Alaska & Yakutat & 0.05 & No comments \\
\hline $3 / 3 / 1985$ & $E Q$ & 7.8 & Chile & Yakutat & & No comments \\
\hline $11 / 17 / 1987$ & EQ & 6.9 & Gulf of Alaska & Yakutat & 0.06 & No comments \\
\hline $11 / 30 / 1987$ & $\mathrm{EQ}$ & 7.6 & Gulf of Alaska & Yakutat & 0.43 & Boats bumped together \\
\hline $3 / 6 / 1988$ & $\mathrm{EQ}$ & 7.6 & Gulf of Alaska & Yakutat & 0.2 & No comments \\
\hline $7 / 30 / 1995$ & $\mathrm{EQ}$ & 7.8 & Chile & Yakutat & 0.06 & No comments \\
\hline $6 / 23 / 2001$ & $\mathrm{EQ}$ & 8.2 & Peru & Yakutat & 0.03 & No comments \\
\hline $12 / 26 / 2004$ & EQ & 8.8 & $\begin{array}{l}\text { Sumatra, } \\
\text { Indonesia }\end{array}$ & Yakutat & 0.08 & No comments \\
\hline $11 / 15 / 2006$ & EQ & 7.8 & $\begin{array}{l}\text { Kuril Islands, } \\
\text { Russia }\end{array}$ & Yakutat & 0.13 & No comments \\
\hline $1 / 13 / 2007$ & EQ & 8.2 & $\begin{array}{l}\text { Kuril Islands, } \\
\text { Russia }\end{array}$ & Yakutat & 0.05 & No comments \\
\hline $9 / 29 / 2009$ & $E Q$ & 8.1 & Samoan Islands & Yakutat & 0.08 & No comments \\
\hline $2 / 27 / 2010$ & $\mathrm{EQ}$ & 8.5 & Chile & Yakutat & 0.36 & No comments \\
\hline $3 / 11 / 2011$ & $\mathrm{EQ}$ & 8.3 & Honshu, Japan & Yakutat & 0.35 & No comments \\
\hline $10 / 28 / 2012$ & EQ & 7.5 & $\begin{array}{l}\text { Haida Gwaii, } \\
\text { Canada }\end{array}$ & Yakutat & 0.15 & No comments \\
\hline $2 / 6 / 2013$ & $E Q$ & 7.4 & Solomon Islands & Yakutat & 0.07 & No comments \\
\hline
\end{tabular}

a'Lander (1996) 


\section{July 10, 1958, Lituya Bay earthquake}

In 1958 a Ms 7.9 earthquake was strongly felt in the Yakutat area, with prolonged ground shaking for about 3-4.5 minutes. Several airport facilities and the runway were damaged, but at Yakutat damage to most residential and commercial buildings was slight due to wood-frame type construction. The $1 \mathrm{~m}(3 \mathrm{ft})$ waves reported in Monti Bay were probably due to a submarine landslide at the southern end of Khantaak Island (fig. 2), in the same area that slid in 1899. According to Lander (1996), several people had gone to Khantaak Island to pick berries on this day. At around 9 pm, part of the group decided to take a boat back to Yakutat. As they set off they noticed trees swaying. Looking back to sea they saw a huge wave approaching but were able to outrun the wave in the boat. The three people left on the island were never found. A section of the island tip $45 \times 305$ $\mathrm{m}(150 \times 1,000 \mathrm{ft})$ had slumped into the water; the nearly vertical cliff left by the slide was about $4 \mathrm{~m}(13 \mathrm{ft})$ high. The water was $27 \mathrm{~m}$ (90 ft) deep over what had been land. The wave, observed by a resident on the shore at Yakutat, had an estimated height of 4.5 to $6 \mathrm{~m}$ (15-20 ft) initially. It was estimated to have been $\sim 1 \mathrm{~m}(3 \mathrm{ft})$ at the head of Monti Bay. The submarine landslide at the northern end of Khantaak Island left a cliff estimated to be 3-5 m (10-15 ft) high.

\section{March 27, 1964, Great Alaska Earthquake}

The $\mathrm{M}_{\mathrm{W}}$ 9.2 Great Alaska Earthquake generated tsunami waves that destroyed many Alaska coastal communities and affected the west coast of the United States, Canada, and Hawaii. This earthquake was felt strongly in Yakutat; the ground shaking lasted for about 6 minutes (Plafker and others, 1969). Several earthquake-related waves were observed during and after the earthquake, but none of them reached above extreme high water level or caused any damage in the vicinity of Yakutat (Plafker and others, 1969). At Yakutat, a single wave was observed in Monti Bay during the earthquake. The churned and muddy water indicated that a landslide probably occurred at Point Turner at the southern end of Khantaak Island (fig. 2), close to the area where slides occurred in 1899 and 1958. Lander (1996) also noted that examination from the air the next day showed slumping near Point Turner with much debris in the bays and lagoons. About 1 hour and 25 minutes after the earthquake, the tectonic tsunami waves generated in the Gulf of Alaska began arriving in Monti Bay. These waves were recorded on the Yakutat tidal gauge with a maximum wave height of about $2 \mathrm{~m}(6.5 \mathrm{ft})$. Figure 5 shows a comparison of the tsunami waves recorded by the Yakutat tidal station on March 28, 1964, with the predictions of the Alaska tsunami model (Nicolsky and others, 2011; Nicolsky, 2012), which employs a recently developed source function of the 1964 earthquake (Suleimani, 2011). The model provides good agreement with the observed wave phase for up to 8 hours of wave propagation, and also a good fit to the wave amplitudes recorded by the Yakutat tidal station.

Although the 1964 tsunami did not result in any inundation or damage at Yakutat, we considered an extended tsunami source that includes the 1964 rupture area and the YY segment, consistent with inferences based on paleoseismic evidence presented in Shennan and others (2008). As discussed in the "Regional Seismotectonics" section above, this "super-1964" source has a 15 percent larger seismic moment than the 1964 event. We constructed two hypothetical tsunami scenarios (scenarios 1 and 2 in table 3 ) that are based on the super-1964 source.

\section{March 11, 2011, Tohoku earthquake}

The most recent catastrophic tsunami of the century was generated by the March 11, 2011, Tohoku earthquake, which produced a small wave in Yakutat. According to the National Tsunami Warning Center database (http://ntwc. arh.noaa.gov/previous.events/?p=03-11-11_Honshu), the maximum wave amplitude recorded by the tide gauge was $35 \mathrm{~cm}$ (13.8 in). The far-field Tohoku tsunami did not result in a significant wave at Yakutat due to its distance from the tsunami source and directivity patterns of the energy propagation. Waves were directed primarily to the northwest, toward the coast of Japan, and to the southeast, in the Pacific Ocean (Tang and others, 2012). There are no accounts of any observations of this tsunami at Yakutat, probably due to the fact that it arrived at 4:25 a.m.

\section{METHODOLOGY AND DATA}

\section{GRID DEVELOPMENT AND DATA SOURCES}

One of the problems in tsunami modeling is that the governing equations for water dynamics are continuous. In this report, we discretize the shallow-water equations in spherical coordinates by a finite difference method in which the stated variables of sea level and water fluxes are staggered on an Arakawa C-grid (Arakawa and Lamb, 1981). In this layout, the water depth and the sea level are defined at grid cell centers, while the water fluxes are defined at cell boundaries. To achieve satisfactory accuracy of numerical results, we need to use a grid that is fine enough, providing an adequate number of points per wavelength (Titov and Synolakis, 1995, 1997). To compute a detailed map of potential tsunami inundation triggered by local and distant earthquakes, we employ a series of nested computational grids. A nested grid allows for higher resolution in areas where it is needed without expending computer resources in areas where it is not. The bathymetric and topographic relief in each nested grid is based on digital elevation models (DEMs) developed at the National Center for Environmental Information (NCEI) of the National Oceanic \& Atmospheric Administration (NOAA) in Boulder, Colorado. The extent of each grid used for inundation mapping of Yakutat is listed in table 2. The coarsest grid spans the central and northern Pacific Ocean and has a resolution of 2 arc-minutes $(\approx 2 \mathrm{~km})$, while the highest-resolution grid covers the community (fig. 6). The spatial resolution of the high-resolution grid (see table 2) satisfies NOAA minimum recommended requirements for computation of tsunami inundation (National Tsunami Hazard Mitigation Program [NTHMP], 2010). 


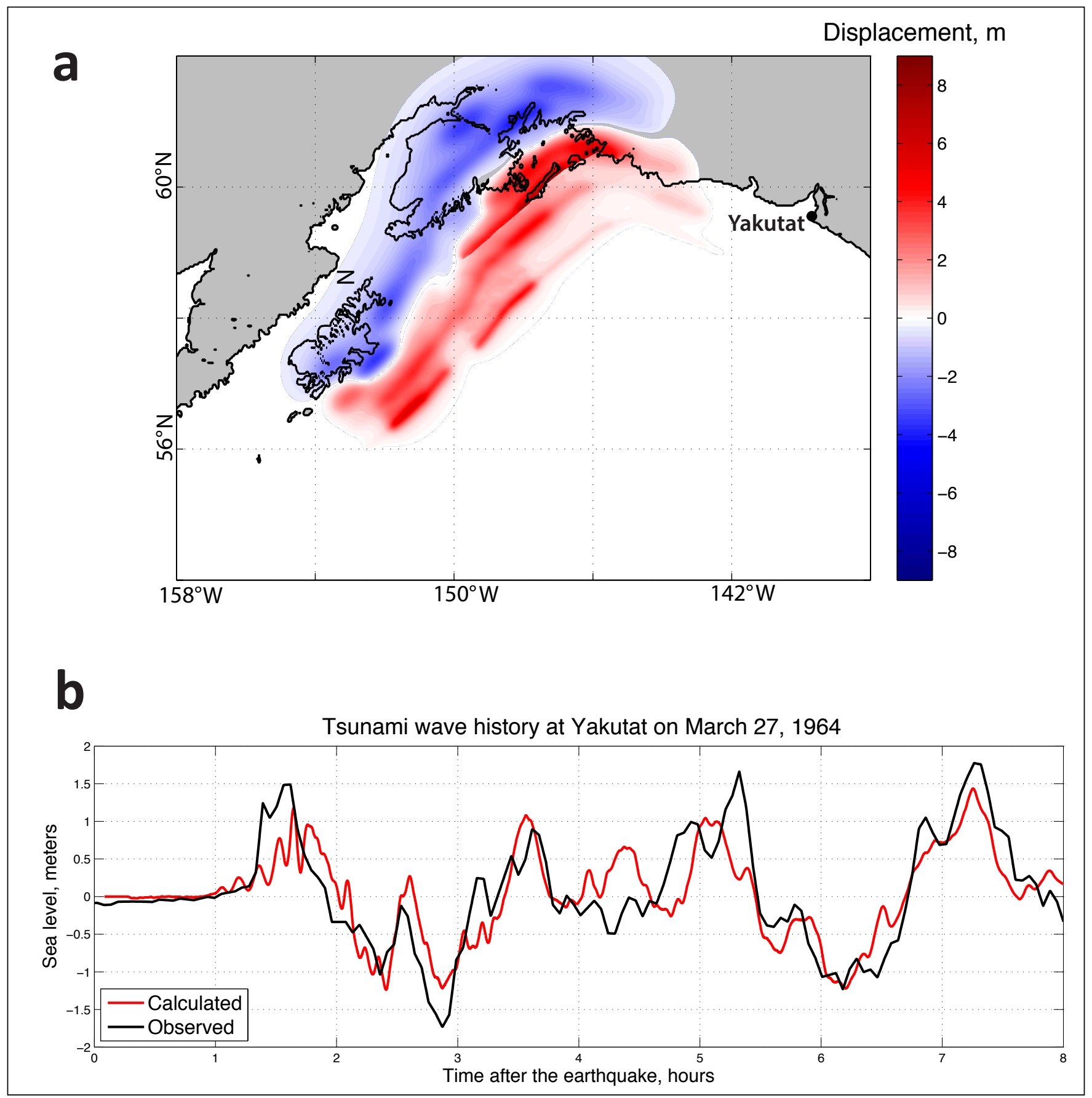

Figure 5. (a) Vertical coseismic deformations for the source model of the 1964 Alaska tsunami (Suleimani, 2011). (b) Recorded sea level at Yakutat compared with the time series calculated using this source function.

Table 2. Nested grids used to compute propagation of tsunami waves to the community of Yakutat. High-resolution grids are used to compute the inundation. Note that the grid resolution in meters is not uniform and is used to illustrate grid fineness near the communities. The first dimension is the longitudinal grid resolution; the second is the latitudinal.

\begin{tabular}{|l|c|c|c|c|}
\hline \multirow{2}{*}{ Grid name } & \multicolumn{2}{|c|}{ Resolution } & \multirow{2}{*}{ West-East boundaries } & \multirow{2}{*}{ South-North boundaries } \\
\cline { 2 - 3 } & Arc-seconds & Meters & & \\
\hline Northern Pacific, Level 0 & $120^{\prime \prime} \times 120^{\prime \prime}$ & $1,850 \times 3,700$ & $120^{\circ} 00^{\prime} \mathrm{E}-100^{\circ} 00^{\prime} \mathrm{W}$ & $10^{\circ} 00^{\prime} \mathrm{N}-65^{\circ} 00^{\prime} \mathrm{N}$ \\
\hline Southeastern Alaska, Level 1 & $24^{\prime \prime} \times 24^{\prime \prime}$ & $402 \times 740$ & $130^{\circ} 00^{\prime} \mathrm{W}-141^{\circ} 00^{\prime} \mathrm{W}$ & $54^{\circ} 00^{\prime} \mathrm{N}-60^{\circ} 00^{\prime} \mathrm{N}$ \\
\hline Yakutat 8-sec grid, Level 2 & $8^{\prime \prime} \times 8^{\prime \prime}$ & $132 \times 246$ & $138^{\circ} 49^{\prime} \mathrm{W}-140^{\circ} 30^{\prime} \mathrm{W}$ & $59^{\circ} 00^{\prime} \mathrm{N}-60^{\circ} 06^{\prime} \mathrm{N}$ \\
\hline Yakutat 3-sec grid, Level 3 & $2.7^{\prime \prime} \times 2.7^{\prime \prime}$ & $44 \times 82$ & $139^{\circ} 24^{\prime} 50^{\prime \prime} \mathrm{W}-140^{\circ} 25^{\prime} 18^{\prime \prime} \mathrm{W}$ & $59^{\circ} 19^{\prime} 54^{\prime \prime} \mathrm{N}-59^{\circ} 51^{\prime} 11^{\prime \prime} \mathrm{N}$ \\
\hline Yakutat, high-resolution grid & $0.9^{\prime \prime} \times 0.53^{\prime \prime}$ & $14.5 \times 16.5$ & $139^{\circ} 35^{\prime} 45^{\prime \prime} \mathrm{W}-139^{\circ} 54^{\prime} 12^{\prime \prime} \mathrm{W}$ & $58^{\circ} 26^{\prime} 17^{\prime \prime} \mathrm{N}-59^{\circ} 39^{\prime} 11^{\prime \prime} \mathrm{N}$ \\
\hline
\end{tabular}




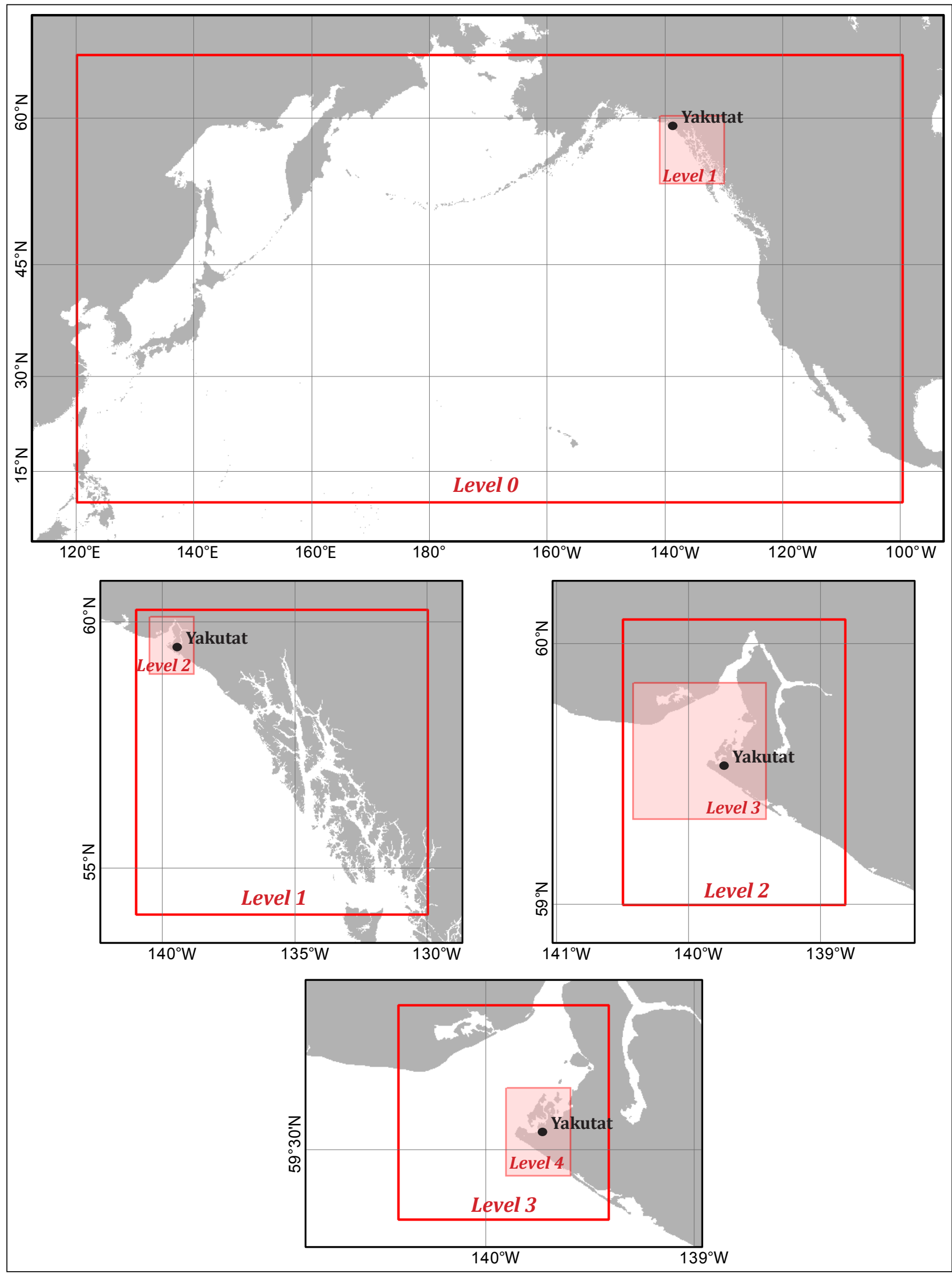

Figure 6. Nested bathymetry/topography grids for numerical modeling of tsunami propagation and runup. The lowest resolution grid, Level 0 , covers the central and northern Pacific Ocean. Location of each embedded grid is marked by a pink-shaded rectangle. Refer to table 2 for grid parameters. 
The bathymetric data for the 2-arc-minute resolution grid (Level 0 in fig. 6) is extracted from the ETOPO2 dataset (NCEI; http://www.ngdc.noaa.gov/mgg/bathymetry/relief. html). To develop the $14.5 \times 16.5 \mathrm{~m}, 2.7-, 8$-, and 24-arcsecond resolution grids, we obtained shoreline, bathymetric, and topographic digital datasets from several U.S. federal and academic agencies, including NOAA's National Ocean Service, Office of Coast Survey, and NCEI; the U.S. Fish \& Wildlife Service (FWS); the U.S. Geological Survey (USGS); and the U.S. Army Corps of Engineers (USACE). All data were shifted to World Geodetic System 1984 (WGS 84) horizontal and Mean Higher High Water (MHHW) vertical datums. The data sources and methodology used to create the 24-arc-second DEM are described in greater detail in Caldwell and others (2012). The 8- and 2.7-arc-second DEMs and the original high-resolution grid for Yakutat are described in Caldwell and others (2011).

The high-resolution grid for Yakutat, which was used to calculate the extent of inundation and flow depths, was enhanced by including other datasets that are described below. To update the existing NOAA high-resolution digital elevation model (DEM) of the Yakutat area we incorporated the survey data from the Alaska Division of Community and Regional Affairs (DCCED/DCRA), the extent of which is shown in figure 7. We extracted elevation contours and shoreline information from the DCRA survey data and created a triangulated irregular network (TIN) using an ArcGIS function with the soft breaklines option (http://resources.arcgis.com/en/help/main/10.1/index. html\#//00q90000001v000000). The TIN was then clipped to the DCRA study area and converted to a raster DEM using the ArcGIS 3D Analyst "Convert TIN to Raster" function (http://resources.arcgis.com/en/help/main/10.1/index. html\#//00q900000077000000).

The original elevation contours are in the Geoid99 vertical datum, so we adjust the resulting raster DEM to the MHHW vertical datum by adding $0.37 \mathrm{~m}(1.21 \mathrm{ft})$. The vertical shift is determined by finding the mean difference between the developed raster DEM datum and the RTK GPS survey of the near-shore area around Yakutat as well as the available benchmark data (National Oceanic and Atmospheric Administration, http://tidesandcurrents.noaa.gov/benchmarks.html?id=9453220). The one-time survey in Yakutat was conducted April 29-May 1, 2013, to collect individual single measurements of the elevations in the coastal zone. Locations of these GPS measurements in Yakutat are shown in figure 7. The collected GPS measurements had 0.03-0.05 $\mathrm{m}(1.2-2$ in) lateral and vertical accuracy with respect to the base station (Leica Geosystems AG, 2002).

Inspection of the boundary between the NOAA DEM and the converted raster DEM revealed some areas of sharp discontinuity at the border of the two DEMs at the bathymetric/topographic interface. To remove these artifacts from the merged product of the two DEMs, we followed previously established workflows (Gesch and Wilson, 2002) and created a shoreline buffer region between the converted raster DEM and the NOAA DEM (fig. 7). The buffer region that extended into the NOAA DEM was used to smooth the transition between the two DEMs. Specifically, the smoothing was achieved by creating a set of contours from the NOAA DEM in the buffer region, and then adding these contours to the TIN and recreating the adjusted raster DEM. The values from the adjusted raster DEM were then merged into the existing NOAA DEM, replacing the original values with the newly interpreted elevations.

\section{NUMERICAL MODEL OF TSUNAMI WAVE PROPAGATION AND RUNUP}

A NOAA technical memorandum outlines the major requirements for numerical models used in inundation mapping and tsunami forecasting and describes a procedure for model evaluation (NTHMP, 2010). There are two major components in this process. The first is model validation, which ensures that the model correctly solves the appropriate equations of motion by comparing model results with known solutions; this is achieved through analytical and laboratory benchmarking. The second component is model verification (testing the model) using observations of real events through field data benchmarking.

The numerical model currently used by the Alaska Earthquake Center for tsunami inundation mapping has been validated through a set of analytical benchmarks and tested against laboratory and field data (Nicolsky and others, 2011; Nicolsky, 2012). The model solves the nonlinear shallow-water equations using a finite-difference method on a staggered grid, and uses ocean surface displacement due to an underwater earthquake as an initial condition. For any coarse-fine pair of computational grids, we apply a timeexplicit numerical scheme as follows. First, we compute the water flux in a coarse-resolution grid. These computed flux values are used to define the water flux on a boundary of the fine-resolution grid. Next, the water level and then the water flux are calculated over the fine-resolution grid. Finally, the water level computed in the fine-resolution grid is used to define the water level in the area of the coarse-resolution grid that coincides with the fine grid. Despite the fact that developed nested grids decrease the total number of grid cells needed to preserve computational accuracy in certain regions of interest, actual simulations are still prohibitive without implementing parallel computing. We use the Portable Extensible Toolkit for Scientific computation (PETSc), which provides sets of tools for the parallel numerical solution of shallow-water equations. In particular, each computational grid listed in table 2 can be subdivided among an arbitrary number of processors. The above-mentioned passing of information between the water flux and level is implemented efficiently using PETSc subroutines.

With the primary goal of model verification, we performed a numerical modeling study of the far-field Tohoku tsunami. We note that among many reasons for model verification presented by Synolakis and others (2007), the one that carries special importance for distant tsunami events such as the Tohoku tsunami is ensuring the quality of the DEM nesting. Several deformation models representing the slip distribution of the 2011 Tohoku earthquake were published after the event. Here we employ Shao and others' (2011) finite 
fault inversions model phase III. For each fault we calculate the corresponding vertical coseismic deformation using Okada's (1985) formulas. The resulting vertical deformation is illustrated in figure 8a. Figure $8 \mathrm{~b}$ shows a comparison between the observed wave history at Yakutat as recorded by the Yakutat tidal station, and the calculated time series at the same location. Note that the comparison between the computed and measured water-level dynamics is relatively good for the first 2-3 hours after the wave arrival to the tidal station. Similar to Tang and others (2012), we observe a time shift between the computed and observed waves. We apply the time correction of $\delta \mathrm{T}=12 \mathrm{~min}$ to the calculated time series, which is the same value that Tang and others (2012) used for Yakutat. The probable cause of this time lag is errors in the bathymetry and some dispersion effects.

The numerical modeling of this historic tsunami demonstrates that the chosen numerical model of tsunami propagation and runup generates tsunami waveforms that are consistent with the observed wave phases. The model also provides a good approximation to recorded tsunami

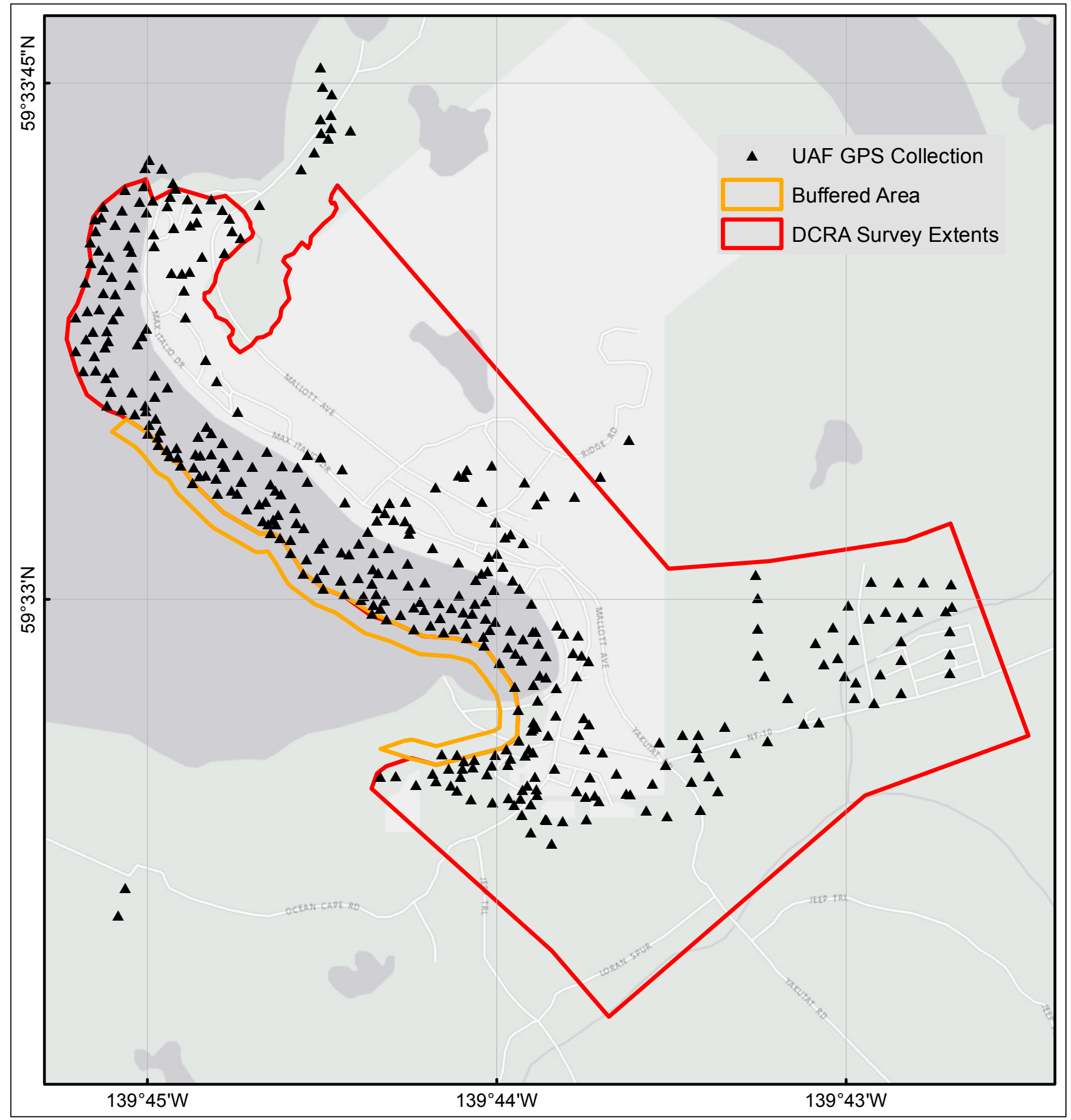

Figure 7. Extents of survey data from the Division of Community and Regional Affairs (DCRA), the shoreline buffer region between the converted raster DEM and the NOAA DEM, and locations of the GPS measurements in Yakutat. 
amplitudes in Yakutat, which indicates that the proposed coseismic deformation model adequately describes the coseismic slip distribution, and the DEM nesting is selected appropriately.

We assess hazards related to tectonic tsunamis at Yakutat by performing model simulations for each hypothetical earthquake source scenario. To simulate tsunami dynamics related to a seafloor deformation caused by an earthquake, we assume some simplifications. First, the initial displacement of the ocean surface is equal to the vertical displacement of the ocean floor induced by the earthquake rupture process. Second, we do not account for the finite speed of the rupture propagation along the fault, and so we consider the oceanbottom displacement to be instantaneous. Third, the initial topography is modified to account for coseismic deformation of land resulting from the earthquake, which can be either

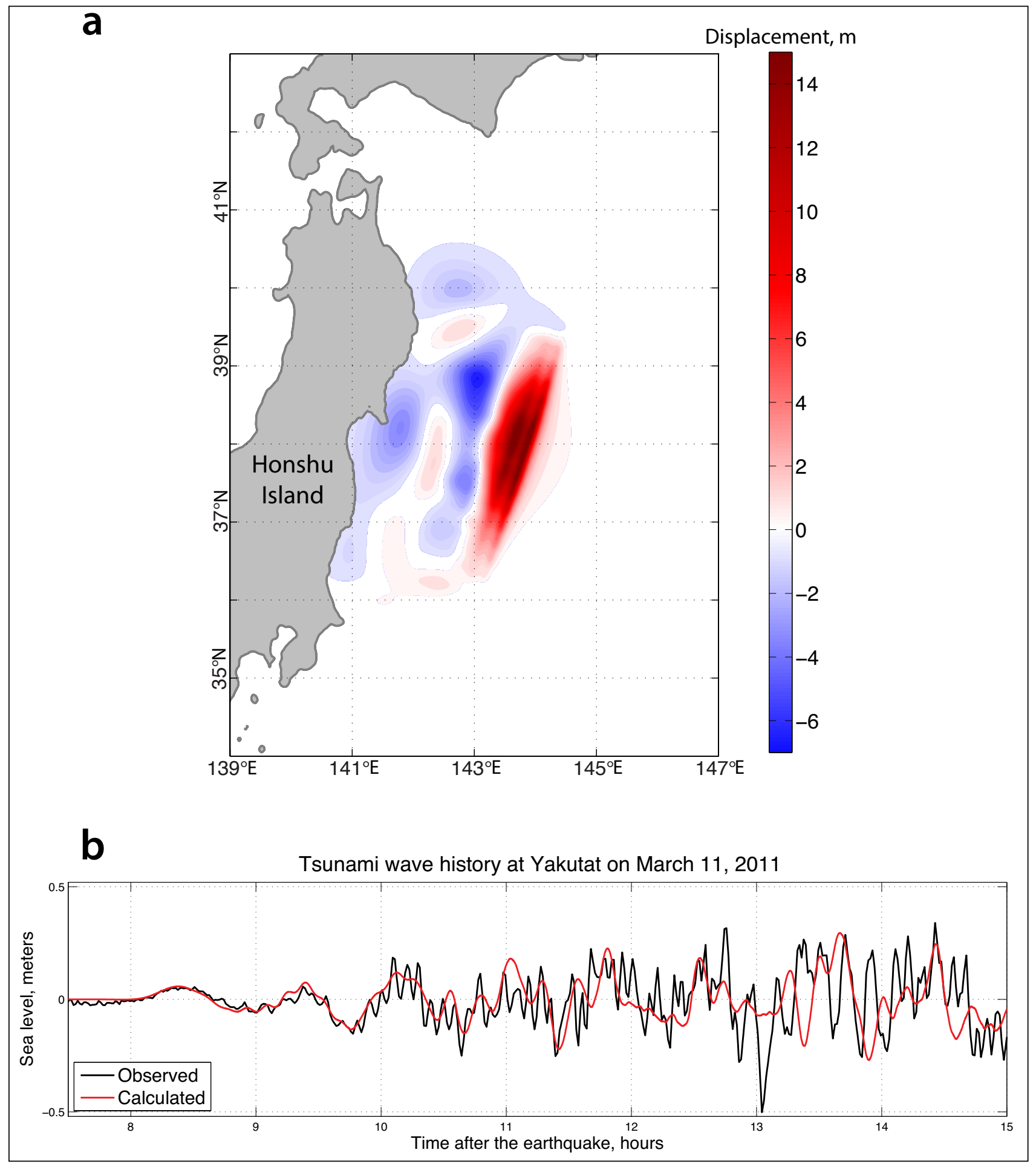

Figure 8. (a) Vertical coseismic deformations for the source model of the 2011 Tohoku tsunami. (b) Recorded sea level at Yakutat compared with the time series calculated using this source function. 
uplift or subsidence depending on the location of a point relative to the earthquake's slip patch.

At the end of a tsunami simulation, in addition to the flow depth value for each of the on-land grid points, we calculate a "mask" that has a value of either 0 if no inundation occurs, or 1 if seawater reaches the grid point at any time. The inundation line approximately follows the 0.5 contour between these 0 and 1 point values and is adjusted visually to account for obstacles or local variations in topography not represented by the DEM. Although the developed algorithm has passed through rigorous benchmarking procedures (Nicolsky and others, 2011; Nicolsky, 2012), some uncertainty in the exact location of the inundation line is unavoidable. Complexities in the modeling process make this uncertainty difficult to quantify. Many factors can affect the estimated location of the inundation line, including suitability of the earthquake source model, accuracy of the bathymetric and topographic data, and adequacy of the numerical model in representing the generation, propagation, and runup of tsunami waves. In this report, we do not attempt to adjust the modeled inundation limits to account for these uncertainty factors. Another important limitation of the model is that it does not take into account the periodic change of sea level caused by tides. We conducted all model runs using bathymetric data that correspond to MHHW at Yakutat. As a result, the elevation of the inundation line could be lower or slightly higher than that given in this report, depending on the tides at the time of a tsunami.

\section{NUMERICAL MODEL FOR LANDSLIDE- GENERATED TSUNAMIS}

To simulate tsunamis produced by hypothetical underwater slope failures in Monti Bay, we use a numerical model with two components: a viscous underwater slide model and a water-wave model. The developed model assumes full coupling between the deforming slide and the water waves that it generates. A coupling of these two components was previously accomplished by Jiang and LeBlond (1992) and later improved by Fine and others (1998). The water-wave component in the above-mentioned articles consists of the nonlinear shallow-water equations. Keep in mind that the shallow-water assumption implies that the length of the wave is much greater than the water depth. When modeling landslide-generated tsunamis, the generated water-level excitations quite often have wavelengths comparable with the water depth. Therefore, the nonlinear shallow-water equations require some corrections (such as additional Boussinesq-type terms) to accurately simulate propagation and runup of the rather short waves.

As described by Kirby and others (in process), in this report we replace the nonlinear shallow equations used to describe the water dynamics in Fine and others (1998) with a shock-capturing Non-Hydrostatic Wave (NHWAVE) model by Ma and others (2012). The NHWAVE model is designed to demonstrate fully dispersive surface wave processes by solving the non-hydrostatic Navier-Stokes equations in so-called $\sigma$ coordinates that follow terrain and the free water surface. Tsunami waves generated by a prescribed submarine landslide can be directly simulated by taking advantage of the $\sigma$ coordinate system. NHWAVE has been benchmarked in Tehranirad and others (2012) for tsunami application using PMEL-135 benchmarks provided by Synolakis and others (2007), and a landslide benchmark developed from results in Enet and Grilli (2007). Recently the NHWAVE model was applied to simulate water waves caused by underwater landslide motion, and was validated using laboratory measurements of turbidity currents and water waves generated by granular landslides (Ma and others, 2013).

We emphasize that the viscous slide model is derived under the assumption that characteristic slide dimensions are much greater than the local slide thickness, and that pressure inside the slide remains hydrostatic (Jiang and LeBlond, 1994). Assier-Rzadkiewicz and others (1997) argued that long-wave approximation could be inaccurate for slopes exceeding 10 degrees. Rabinovich and others (2003) studied the validity of the long-wave approximation for slopes greater than 10 degrees and found that for a slope of 16 degrees, the possible error in the gravitational forcing was 8 percent, and for the maximum slope of 23 degrees in their study, the possible error was 15 percent. Because the average pre-earthquake offshore slopes range from 10 to 30 degrees in Monti Bay near Yakutat, the potential error could be higher. Generation of the water gravity waves strongly depends on the relative speeds of the gravity wave and the slide front. Resonance occurs when the speed of the slide front is equal to the local long-wave speed (Rabinovich and others, 2003), resulting in an abnormally large wave. Further scientific studies are necessary to estimate how an error in the slide forcing manifests itself in the modeled wave height errors for Yakutat. Nevertheless, the viscous underwater slide component was used to simulate landslide-generated tsunamis in Seward, Whittier, and Valdez (Suleimani and others, 2010; Nicolsky and others, 2012, 2013), and is used here for Yakutat. Benchmarking procedures for numerical models describing a deformable slide and its coupling with water waves have not yet been developed.

\section{HYPOTHETICAL TECTONIC TSUNAMI SOURCES}

We describe below all tsunami sources that were used to calculate propagation and runup of tsunami waves and included in calculations of the composite extent of inundation and the composite distribution of flow depths. The coseismic deformation patterns for each scenario are shown in figure 9; table 3 provides a summary of the ten scenarios. In modeling the selected tsunami sources we assume that the initial displacement of the ocean surface is equal to the vertical displacement of the ocean floor induced by the earthquake rupture process. As previously described, we do not account for the finite speed of the rupture propagation along the fault, and we consider the ocean-bottom displacement to be instantaneous. 
Table 3. JDM = Johnson deformational model (Johnson and others, 1996); SDM = Suleimani deformational model (Suleimani, 2011); SAFRR = USGS Science Application for Risk Reduction project model (Ross and others, 2012).

\begin{tabular}{|c|c|c|c|c|c|}
\hline \# & $\mathbf{M}_{\mathbf{w}}$ & Description & $\begin{array}{l}\text { Maximum slip } \\
\quad \mathrm{m}(\mathrm{ft})\end{array}$ & $\begin{array}{l}\text { Maximum } \\
\text { subsidence } \\
\mathrm{m}(\mathrm{ft})\end{array}$ & $\begin{array}{l}\text { Maximum } \\
\text { Uplift } \\
\mathrm{m}(\mathrm{ft})\end{array}$ \\
\hline 1 & 9.3 & $\begin{array}{l}\text { Multi-segment event based on JDM: Rupture of the KI, } \\
\text { KP, PWS, and YY segments }\end{array}$ & $22.1 \quad(72.5)$ & $5.5(18.0)$ & $8.4(27.6)$ \\
\hline 2 & 9.3 & $\begin{array}{l}\text { Multi-segment event based on SDM: Rupture of the KI, } \\
\text { KP, PWS, and YY segments }\end{array}$ & $22.5 \quad(73.8)$ & $4 \quad(13.1)$ & $9.2(30.2)$ \\
\hline 3 & 9.2 & $\begin{array}{l}\text { Multi-segment event: Rupture of the PWS, KP, and KI } \\
\text { segments with Tohoku-type slip distribution in the } \\
\text { downdip direction }\end{array}$ & $36.5 \quad(119.8)$ & $4 \quad(13.1)$ & $14.5(47.6)$ \\
\hline 4 & 9.2 & $\begin{array}{l}\text { Multi-segment event: Rupture of the PWS, KP, KI, and } \\
\text { YY segments with Tohoku-type slip distribution in the } \\
\text { downdip direction }\end{array}$ & $36.5 \quad(119.8)$ & $4.6(15.1)$ & $10.1(33.1)$ \\
\hline 5 & 9.0 & $\begin{array}{l}\text { Event in the Gulf of Alaska region, uniform slip along } \\
\text { strike (PWS and KP segments) and Tohoku-type slip } \\
\text { distribution in the downdip direction }\end{array}$ & $44.4 \quad(145.7)$ & $8 \quad(26.2)$ & $13.5(44.3)$ \\
\hline 6 & 9.0 & $\begin{array}{l}\text { Event in the Gulf of Alaska region, variable slip along } \\
\text { strike (PWS and KP segments) and Tohoku-type slip } \\
\text { distribution in the downdip direction }\end{array}$ & $58.1 \quad(190.6)$ & $7.2(23.6)$ & $11.1(36.4)$ \\
\hline 7 & 9.0 & The SAFRR Tsunami Scenario (SEM and SH segments) & $(246.1)$ & $2.8 \quad(9.2)$ & $14.8(48.6)$ \\
\hline 8 & 7.7 & The Otmeloi fault rupture & $(26.2)$ & $0.5 \quad(1.6)$ & $5 \quad(16.4)$ \\
\hline 9 & 7.7 & The Yakutat fault rupture & $(26.2)$ & $0.4 \quad(1.3)$ & $5.1(16.7)$ \\
\hline 10 & 8.0 & A model of the 1899 Yakutat Bay earthquake & $(32.8)$ & $0.9 \quad(3.0)$ & $9.6(31.5)$ \\
\hline
\end{tabular}

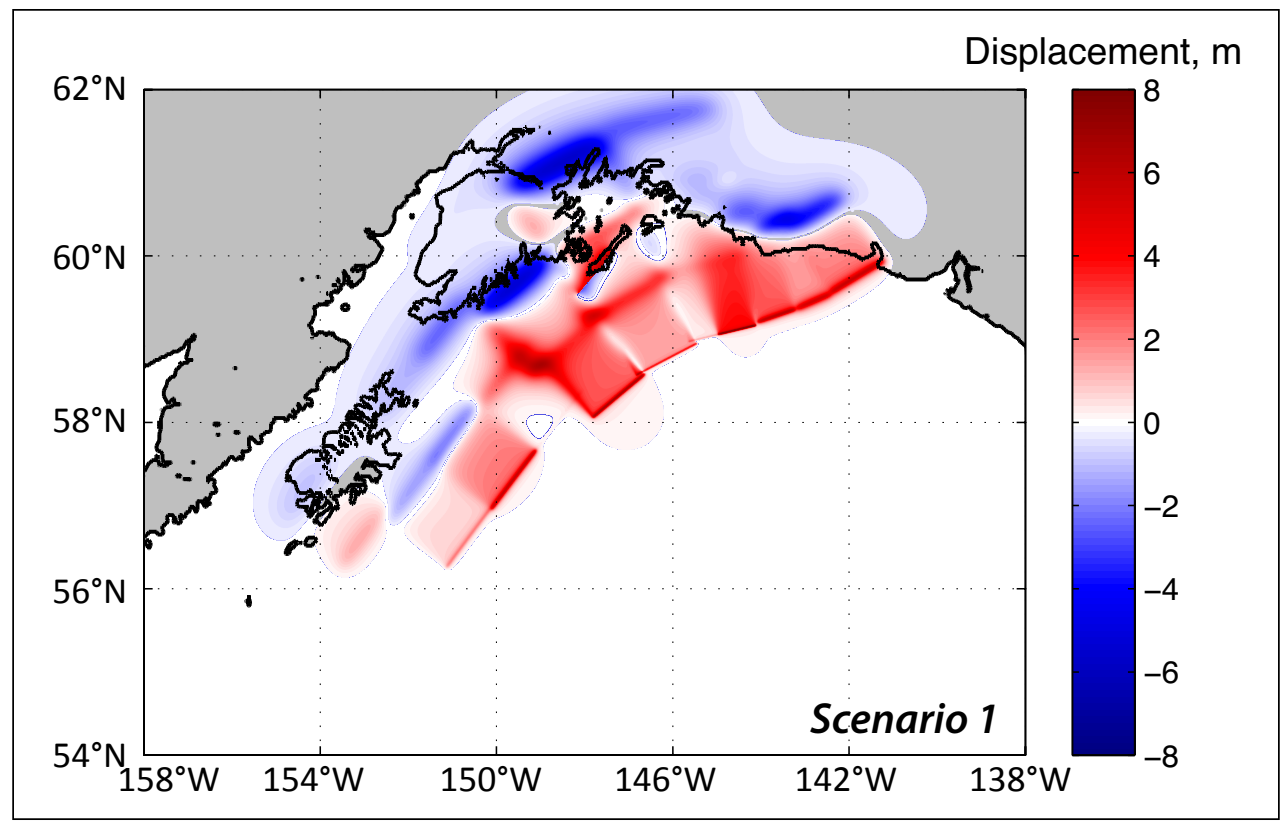

Figure 9. Vertical coseismic deformations corresponding to tectonic scenario 1 (data in table 3). 


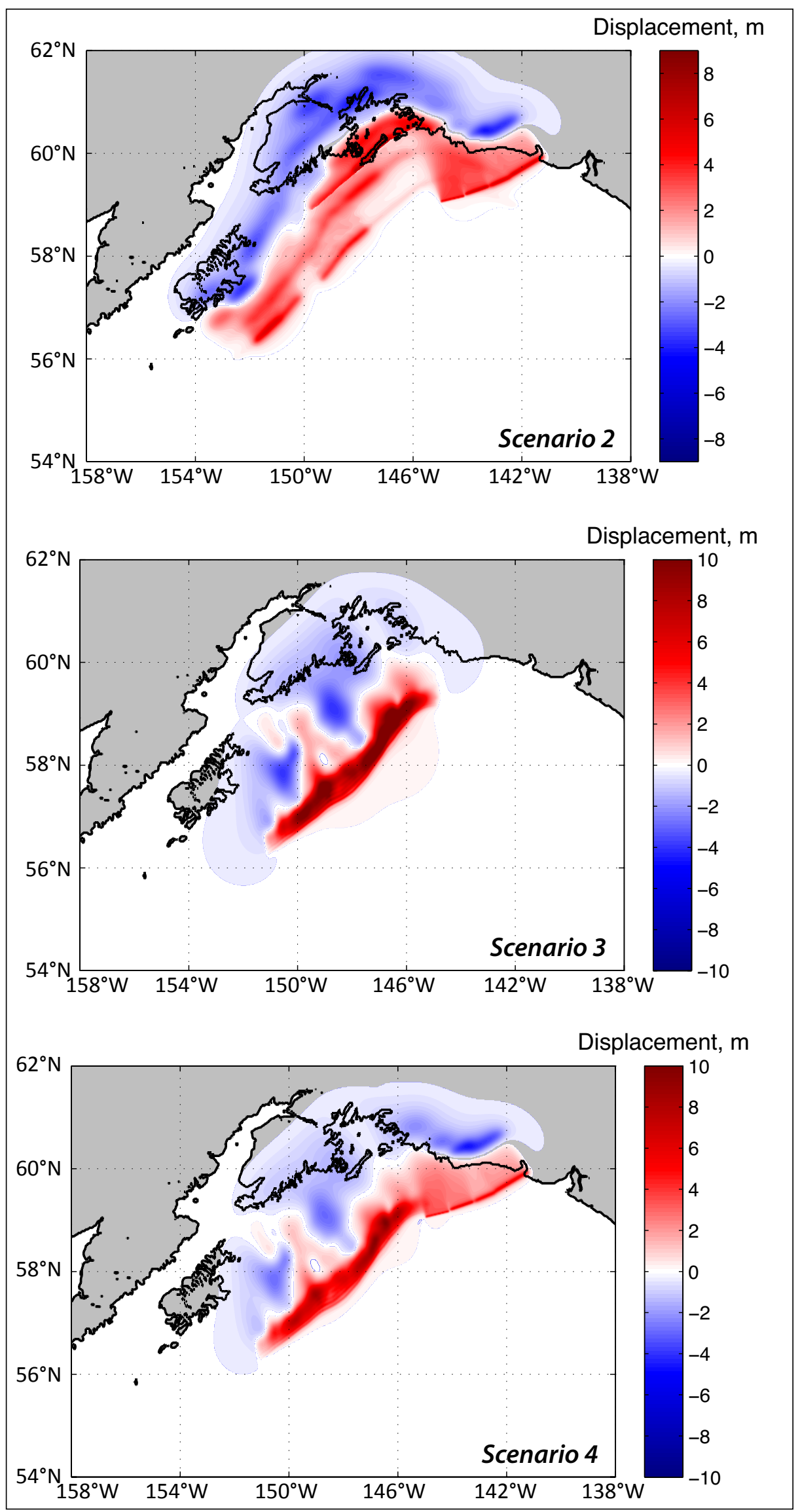

Figure 9. Vertical coseismic deformations corresponding to tectonic scenarios 2-4 (data in table 3). 


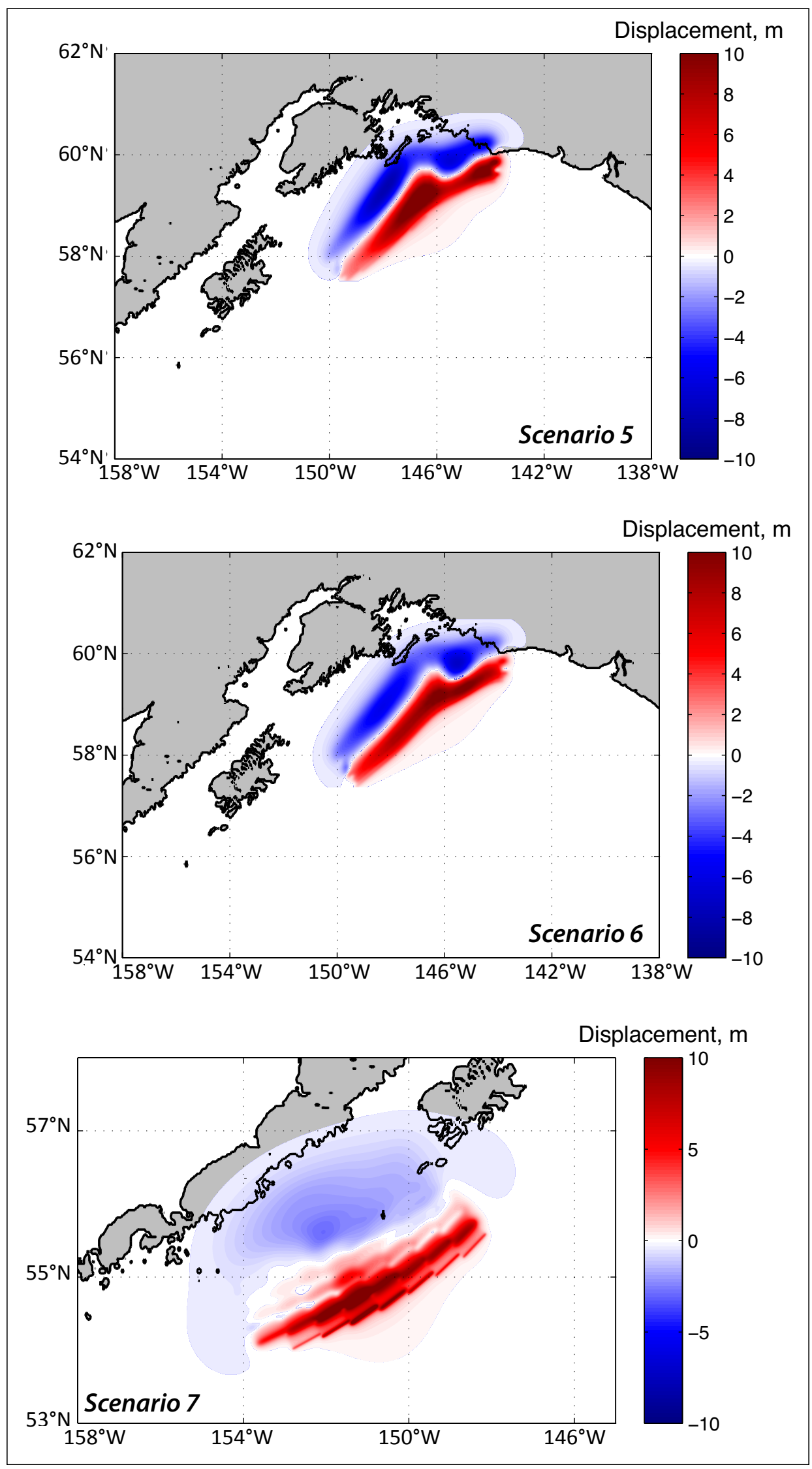

Figure 9. Vertical coseismic deformations corresponding to tectonic scenarios 5-7 (data in table 3). 


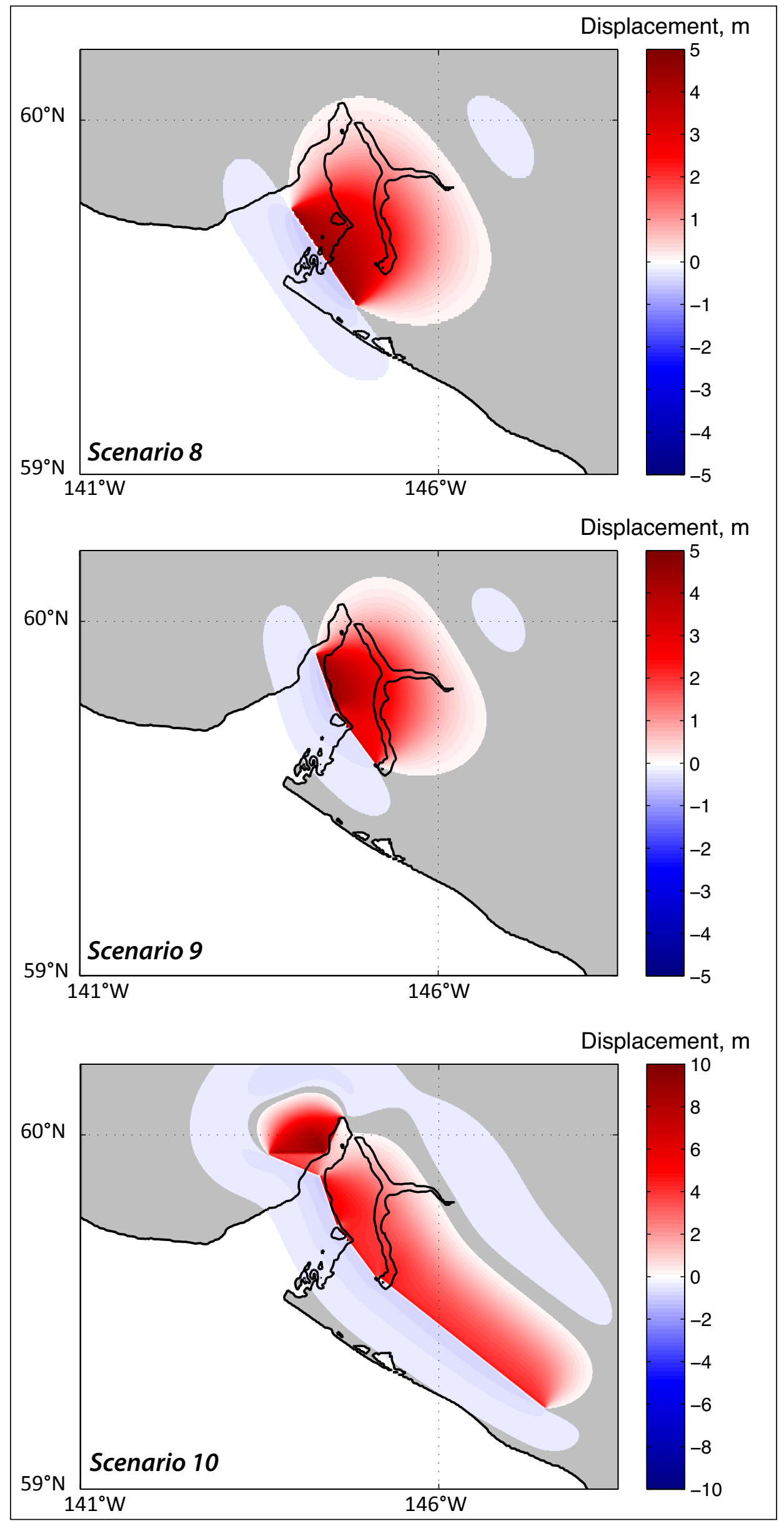

Figure 9. Vertical coseismic deformations corresponding to tectonic scenarios 8-10 (data in table 3). 


\section{Source models of the multi-segment Great Alaska Earthquake}

The 1964 tectonic tsunami affected numerous communities along the Pacific Northwest coast, Hawaii, and Alaska. This tsunami was studied in depth by several investigators (Plafker, 1967; Wilson and Tørum, 1968). Plafker (1967) gives a detailed description of the motion observed on the Patton Bay fault during the 1964 Great Alaska Earthquake, and provides a full report of the surface rupture and fault motion as well as several pieces of evidence suggesting that the fault continues on the ocean floor well past the region where it is currently mapped. Holdahl and Sauber (1994) applied Plafker's description to construct their model of the Patton Bay fault, which was used in an inversion of geodetic data. Johnson and others (1996) used the results of Holdahl and Sauber (1994) to augment their joint inversion of geodetic and tsunami data and to further reconstruct coseismic deformation models of the 1964 earthquake. To derive a slip distribution, they inverted far-field tsunami waveforms from 23 tidal stations in the Pacific Ocean and geodetic data in the form of vertical and horizontal displacements. The fault model consisted of eight subfaults representing the Kodiak Island (KI) asperity, nine subfaults in the Prince William Sound (PWS) asperity, and one subfault representing the Patton Bay fault, one of the two megathrust splay faults that ruptured during the earthquake (Plafker, 1967). Suito and Freymueller (2009) developed a three-dimensional viscoelastic model in combination with an afterslip model, using realistic geometry with a shallow-dipping elastic slab to describe the postseismic deformation that followed the 1964 earthquake. The authors used the inversion-based model by Johnson and others (1996) as a basis for their coseismic slip model, adjusting it to the new geometry and critically reinterpreting the coseismic data. The newly revised coseismic slip distribution of the 1964 rupture by Suleimani (2011) is based on a model of Suito and Freymueller (2009). Suleimani (2011) used results of the near-field modeling of the 1964 tsunami to constrain the amount of slip placed on intraplate splay faults and to evaluate the extent of the Patton Bay fault. The revised model included contribution of coseismic horizontal displacements into the initial tsunami wave field through the component of ocean surface uplift due to horizontal motion of steep ocean-bottom slopes.

In this study, we use two coseismic deformation models of the 1964 earthquake - the Johnson and others (1996) and the Suleimani (2011) models - to generate vertical displacements of the sea floor during the earthquake. We hereafter reference Johnson and others (1996) as the Johnson deformation model
(JDM) and Suleimani (2011) as the Suleimani deformation model (SDM). These models contribute to scenarios 1 and 2 .

A recent study by Shennan and others (2009) presents geologic evidence that the Prince William Sound and Kodiak Island segments of the 1964 rupture area and a portion of the Yakutat microplate may rupture simultaneously. To evaluate whether this event would make a plausible tsunami scenario for Yakutat, we construct a source function of the multi-segment rupture that encompasses the 1964 rupture. We apply the following constraints based on the hypothetical earthquake model of Shennan and others (2008): (1) the extended source function includes three segments of the Aleutian megathrust: the Prince William Sound (PWS), Kodiak Island (KI), and Yakataga-Yakutat (YY) segments; and (2) the total seismic moment is about 15 percent greater than that of the 1964 earthquake. The new source function produces coseismic vertical uplifts along the Gulf of Alaska coastline segment between the Copper River basin and Yakataga area to facilitate matching the coseismic deformation pattern to paleoseismic data (Shennan and others, 2009).

To construct a rupture model for the YY segment we assume four subfaults whose parameters are listed in table 4 . This offshore hypothetical rupture occurs on the YakutatNorth America megathrust, with the strike following the Khitrov Ridge, then the general direction of the Pamplona Zone faults and ending at the Malaspina fault (fig. 3). We calculate coseismic deformations produced by this segment using Okada's algorithm (Okada, 1985), and then combine them with coseismic deformations produced by rupture models for other segments. This model contributes to scenarios 1,2 , and 4 .

Scenario 1. $\mathrm{A} \mathrm{M}_{\mathrm{W}} 9.3$ multi-segment JDM event: The PWS, $\mathrm{KP}$, and KI segments of the 1964 rupture, and the YY segment. Source function is based on the extension of the JDM.

This model includes coseismic deformation of the PWS, KP, and KI segments of the 1964 rupture, and deformation of the YY segment. Vertical displacements in the 1964 rupture zone are based on the coseismic deformation model by Johnson and others (1996).

Scenario 2. $\mathrm{AM}_{\mathrm{W}} 9.3$ multi-segment SDM event: The PWS, $\mathrm{KP}$, and KI segments of the 1964 rupture, and the YY segment. Source function is based on the extension of the SDM.

This model includes coseismic deformation of the PWS, KP, and KI segments of the 1964 rupture, and deformation of the YY segment. Vertical displacements in the 1964 rupture zone are based on the coseismic deformation model by Suleimani (2011).

Table 4. Fault parameters for the Yakataga-Yakutat (YY) segment.

\begin{tabular}{|c|c|c|c|c|c|c|c|c|}
\hline $\begin{array}{c}\text { Latitude } \\
(\mathbf{} \mathbf{N})\end{array}$ & $\begin{array}{c}\text { Longitude } \\
(\mathbf{} \mathbf{W})\end{array}$ & $\begin{array}{c}\text { Depth } \\
(\mathbf{k m})\end{array}$ & $\begin{array}{c}\text { Length } \\
\mathbf{( \mathbf { k m } )}\end{array}$ & $\begin{array}{c}\text { Width } \\
\mathbf{( k m )}\end{array}$ & $\begin{array}{c}\text { Strike } \\
(\mathbf{d e g} .)\end{array}$ & $\begin{array}{c}\text { Dip } \\
(\mathbf{d e g})\end{array}$ & $\begin{array}{c}\text { Rake } \\
(\mathbf{d e g} .)\end{array}$ & $\begin{array}{c}\text { Slip } \\
(\mathbf{m})\end{array}$ \\
\hline 59.17 & 144.12 & 1 & 50.1 & 190 & 256 & 12 & 90 & 15 \\
\hline 59.36 & 143.23 & 3 & 51.1 & 141 & 250.4 & 10 & 90 & 15 \\
\hline 59.54 & 142.42 & 5 & 47.8 & 114.8 & 245.8 & 6 & 90 & 15 \\
\hline 59.94 & 141.21 & 5 & 79.7 & 99.6 & 237.8 & 8 & 90 & 15 \\
\hline
\end{tabular}




\section{Source models of hypothetical Tohoku-type events in the Gulf of Alaska}

In view of the recent $M_{W} 9.0$ earthquake off the Pacific coast of Tohoku in 2011, we consider a similar-type event in the Gulf of Alaska region. During the Tohoku event a large amount of slip occurred between the subducting and overriding plates near the Japan trench (Fujii and others, 2011; Shao and others, 2011). In this report we model four hypothetical Tohoku-type events in the Gulf of Alaska region with different distribution of slip along strike. We note that although the occurrence of a Tohoku-type event is possible, the available geologic evidence suggests that scenarios based on the 1964 rupture models provide more realistic estimates of future earthquake displacements in the Gulf of Alaska.

Scenario 3. A $\mathrm{M}_{\mathrm{W}} 9.2$ multi-segment event: The PWS, KP, and KI segments with Tohoku-type slip distribution.

We used a recently published model of global subduction zone geometries, called Slab 1.0 (Hayes and others, 2012), to construct hypothetical tsunami sources along the eastern end of the Aleutian megathrust (fig. 1). Suleimani and others (2013) give a detailed description of a sensitivity study aimed at determining which combination of megathrust segments between PWS and SH would produce the highest tsunami amplitudes and runup values in southern Alaska. In all hypothetical tsunami sources included in the sensitivity study the slip was distributed almost uniformly along strike except for the edges of the ruptures, where slip tapers. For the downdip direction, we assumed a concentration of greater slip closer to the shallow part of the rupture, similar to that in the Tohoku 2011 earthquake (Ito and others, 2011). All sources had the same seismic moment, which corresponds to a $\mathrm{M}_{\mathrm{W}} 9.2$ rupture. We conducted a numerical experiment to select the hypothetical source that produces the highest tsunami amplitudes and runup values at Yakutat. The superposition of PWS, KP, and KI segments generated the largest tsunami and was chosen as scenario 3 .

Scenario 4. A $\mathrm{M}_{\mathrm{W}} 9.2$ multi-segment event: The PWS, KP, KI, and YY segments with Tohoku-type slip distribution.

This model includes coseismic deformation of the PWS, $\mathrm{KP}$, and KI segments as described in scenario 3, plus deformation of the YY segment (table 4).

Scenario 5. A $\mathrm{M}_{\mathrm{W}} 9.0$ multi-segment event in the Gulf of Alaska region: The PWS and KP segments with Tohoku-type slip distribution and uniform slip along strike.

This event is a hypothetical Tohoku-type event rupturing the Prince William Sound and Kenai Peninsula segments of the 1964 earthquake. Although scenarios 3 and 4 are also based on the Tohoku-type slip distribution, which means placing larger amounts of slip close to the trench, this scenario and scenario 6 have slightly different geometry, with smaller rupture areas and larger vertical deformations in the near-coastal area at the boundary between the PWS and YY segments (fig. 1). This shallow-water segment of the Yakutat-North America megathrust is best positioned to generate a tsunami wave that could significantly affect the Yakutat region. In this scenario, the slip is uniformly distributed in the along-strike direction and is localized between 4 and $18 \mathrm{~km}(2.5-11.2 \mathrm{mi})$ depth according to the parameterization by Freund and Barnett (1976).

Scenario 6. A $\mathrm{M}_{\mathrm{W}} 9.0$ multi-segment event in the Gulf of Alaska region: The PWS and KP segments with Tohoku-type slip distribution and variable slip along strike.

This event is a hypothetical Tohoku-type event rupturing the Prince William Sound and Kenai Peninsula segments of the 1964 earthquake. The slip is distributed in the alongstrike direction according to the slip deficit model (Suito and Freymueller, 2009) and is localized between 4 and 18 $\mathrm{km}(2.5-11.2 \mathrm{mi})$ depth according to the parameterization by Freund and Barnett (1976).

\section{Source model of a hypothetical tsunamigenic earthquake in the Alaska Peninsula segment of the Alaska-Aleutian subduction zone}

Scenario 7. $\mathrm{AM}_{\mathrm{W}} 9.0$ multi-segment event: The SH and SEM segments based on the SAFRR tsunami scenario.

The USGS Science Application for Risk Reduction (SAFRR) project, in collaboration with NOAA and State of California agencies, has developed a plausible hypothetical tsunami scenario to describe the impacts of a tsunami generated by an earthquake in the Alaska Peninsula region (Ross and others, 2012). The USGS Tsunami Source Working Group defined the scenario source as a M 9.0 earthquake similar to the Tohoku 2011 event, but located between the Shumagin Islands and Kodiak Island, in the SH and SEM segments of the megathrust (fig. 1). The rupture area, represented by 56 subfaults, is about $350 \times 200 \mathrm{~km}$ $(217 \times 124 \mathrm{mi})$, with an average slip of $15.7 \mathrm{~m}(51.5 \mathrm{ft})$ and a maximum slip of $75 \mathrm{~m}$ ( $246 \mathrm{ft})$. The concentration of higher slip closer to the trench was adopted for the SAFRR scenario following the derived slip distributions for the Tohoku earthquake.

\section{Source models of hypothetical tsunamigenic earthquakes in the area of Yakutat Bay}

Plafker and Thatcher (2008) studied the two great Yakutat Bay earthquakes of September 1899 using tectonic, geologic, and seismologic observations. Figure 10 presents plate 2 from their paper, which summarizes uplift and subsidence measurements from the original study of Tarr and Martin (1912), as well as new or revised sites in their 2008 study. We use the thrust faults inferred in their study - the Yakutat, Otmeloi, Esker Creek, and Bancas Point faults - to build local hypothetical tsunami scenarios, which are described below. 


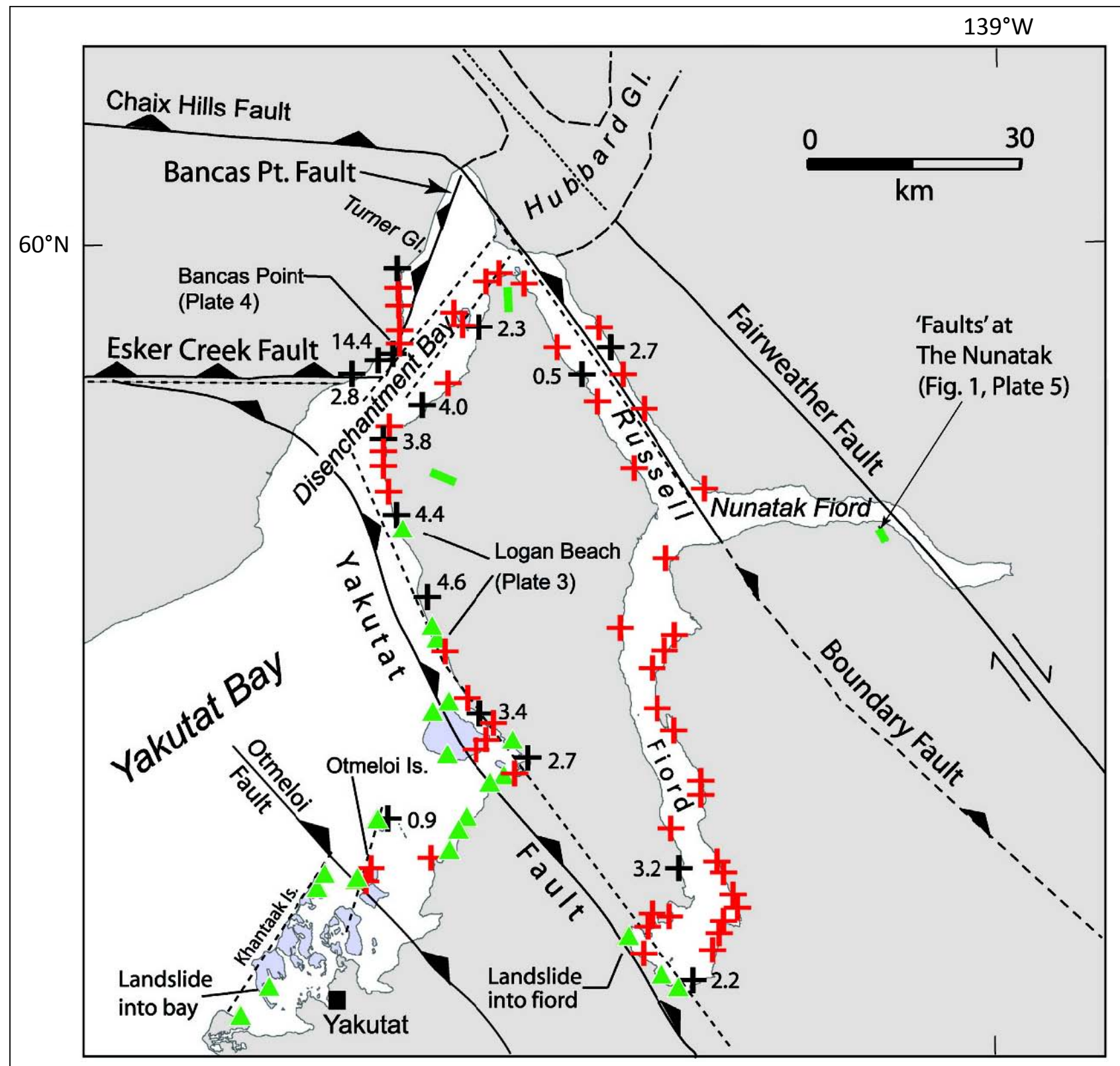

Figure 10. Plate 2 from Plafker and Thatcher (2008), showing a map of Yakutat Bay with uplift and subsidence measured from the original study of Tarr and Martin (1912), as well as the authors' new or revised sites. Red crosses denote uplift, green triangles subsidence; new or revisited sites of uplift measurements indicated by black crosses. Numbers next to symbols indicate uplift in meters at selected sites. Vertical faults (dashed black lines) and minor faults (short green bars) were inferred by Tarr and Martin (1912). Thrust faults inferred by Plafker and Thatcher (2008) are shown by solid black lines with teeth on the upthrown blocks.

Scenario 8. A $\mathrm{M}_{\mathrm{W}} 7.7$ event based on rupture of the Otmeloi fault.

This model represents a hypothetical $\mathrm{M}_{\mathrm{W}} 7.7$ earthquake that ruptures a segment of Otmeloi fault, including its proposed offshore part. It is a single-fault model; parameters are listed in table 5.
Scenario 9. $A M_{W} 7.7$ event based on rupture of the Yakutat fault.

This model represents a hypothetical $\mathrm{M}_{\mathrm{W}} 7.7$ earthquake that ruptures a segment of Yakutat fault, including its proposed offshore part. To account for the change in strike, we used a two-fault model (table 6). 
Table 5. Fault parameters for the Otmeloi fault rupture.

\begin{tabular}{|c|c|c|c|c|c|c|c|c|}
\hline $\begin{array}{c}\text { Latitude } \\
\left({ }^{\mathbf{}} \mathbf{N}\right)\end{array}$ & $\begin{array}{c}\text { Longitude } \\
\left({ }^{\mathbf{}} \mathbf{W}\right)\end{array}$ & $\begin{array}{c}\text { Depth } \\
(\mathbf{k m})\end{array}$ & $\begin{array}{c}\text { Length } \\
(\mathbf{k m})\end{array}$ & $\begin{array}{c}\text { Width } \\
(\mathbf{k m})\end{array}$ & $\begin{array}{c}\text { Strike } \\
(\mathbf{d e g} .)\end{array}$ & $\begin{array}{c}\text { Dip } \\
(\mathbf{d e g} .)\end{array}$ & $\begin{array}{c}\text { Rake } \\
(\mathbf{d e g} .)\end{array}$ & Slip (m) \\
\hline 59.48 & 139.45 & 0.2 & 36.7 & 38 & 326 & 40 & 90 & 8 \\
\hline
\end{tabular}

Table 6. Fault parameters for the Yakutat fault rupture.

\begin{tabular}{|c|c|c|c|c|c|c|c|c|}
\hline $\begin{array}{c}\text { Latitude } \\
\left({ }^{\circ} \mathrm{N}\right)\end{array}$ & $\begin{array}{c}\text { Longitude } \\
\left({ }^{\circ} \mathrm{W}\right)\end{array}$ & $\begin{array}{c}\text { Depth } \\
\text { (km) }\end{array}$ & $\begin{array}{c}\text { Length } \\
\text { (km) }\end{array}$ & $\begin{array}{c}\text { Width } \\
\text { (km) }\end{array}$ & $\begin{array}{l}\text { Strike } \\
\text { (deg.) }\end{array}$ & $\begin{array}{l}\text { Dip } \\
\text { (deg.) }\end{array}$ & $\begin{array}{l}\text { Rake } \\
\text { (deg.) }\end{array}$ & Slip (m) \\
\hline 59.6 & 139.34 & 0.2 & 19.6 & 35.25 & 324 & 40 & 90 & 5 \\
\hline 59.75 & 139.57 & 0.2 & 19.2 & 30 & 341 & 40 & 90 & 8 \\
\hline
\end{tabular}

Table 7. Fault parameters for the model of the 1899 earthquake.

\begin{tabular}{|c|c|c|c|c|c|c|c|c|}
\hline $\begin{array}{c}\text { Latitude } \\
\left({ }^{\circ} \mathrm{N}\right)\end{array}$ & $\begin{array}{c}\text { Longitude } \\
\left({ }^{\circ} \mathrm{W}\right)\end{array}$ & $\begin{array}{c}\text { Depth } \\
\text { (km) }\end{array}$ & $\begin{array}{c}\text { Length } \\
(\mathrm{km})\end{array}$ & $\begin{array}{c}\text { Width } \\
(\mathrm{km})\end{array}$ & $\begin{array}{l}\text { Strike } \\
\text { (deg.) }\end{array}$ & $\begin{array}{c}\text { Dip } \\
\text { (deg.) }\end{array}$ & $\begin{array}{l}\text { Rake } \\
\text { (deg.) }\end{array}$ & Slip (m) \\
\hline 59.6 & 139.35 & 0.2 & 19.6 & 27 & 323.5 & 40 & 90 & 8 \\
\hline 59.75 & 139.57 & 0.2 & 16.3 & 23 & 341.2 & 40 & 90 & 10 \\
\hline 59.89 & 139.67 & 0.2 & 16.8 & 16.6 & 292.7 & 35 & 90 & 8 \\
\hline 60.05 & 139.54 & 0.2 & 12.9 & 16.1 & 204.9 & 35 & 90 & 10 \\
\hline 59.95 & 139.64 & 0.2 & 17.1 & 15.3 & 269.7 & 35 & 90 & 8 \\
\hline 59.23 & 138.41 & 0.2 & 66.7 & 19.7 & 308.1 & 40 & 90 & 8 \\
\hline
\end{tabular}

Scenario 10. A $\mathrm{M}_{\mathrm{W}} 8.0$ event based on a model of the 1899 Yakutat Bay earthquake.

This model represents a hypothetical $\mathrm{M}_{\mathrm{W}} 8.0$ earthquake that ruptures the same segments of the proposed local thrust faults as those in the model of the 1899 earthquake derived by Plafker and Thatcher (2008). Their interpretation of coseismic thrust faulting in the Yakutat area during the 1899 earthquakes was based on new data collected by the authors and also on their reinterpretation of data collected by Tarr and others (1912). The parameters of the six-fault model are listed in table 7.

\section{LANDSLIDE TSUNAMI HAZARD POTENTIAL}

Tsunamis caused by underwater slope failures are a significant hazard in the fjords of coastal Alaska and other high-latitude fjord coastlines (Lee and others, 2006). Kulikov and others (1998) analyzed tsunami catalog data for the North Pacific coast and showed that this region has a long record of tsunami waves generated by submarine and subaerial landslides, avalanches, and rockfalls. For example, as a result of the 1964 earthquake, numerous local submarine and subaerial landslide tsunamis were generated in Alaska (Lander, 1996), which accounted for 76 percent of the tsunami fatalities.

On November 3, 1994, a massive submarine landslide destroyed a timber dock on the east shore of the Skagway harbor. The resultant wave killed one worker and damaged and destroyed boats and docks in the harbor, causing about $\$ 2$ million in damage. A numerical modeling study by Thomson and others (2001) demonstrated that the primary cause of the 1994 Skagway slide was the critical overloading of the slope material at a time of extreme low tide. Human activities can also trigger submarine landslides, for example, rock blasting or loading of slopes during construction work (Masson and others, 2006; Bornhold and others, 2001). With so many diverse mechanisms, assessment of landslide-generated tsunami hazard is a challenging task.

The coast of south-central Alaska has numerous fjords. In a fjord setting, glacial rivers and streams form deltas at the fjord head and deposit sediment that easily loses strength during earthquakes. A primary cause of submarine landslides in fjords is the accumulation of sediments on steep underwater slopes. Masson and others (2006) divide factors that contribute to initiation of submarine landslides into two groups: Factors related to geologic properties of landslide material (such as overpressure due to rapid deposition), and those associated with external events (such as earthquakes or sea level change), noting that usually more than one factor contributes to a single landslide event. Hampton and others (1993) note that in a fjord environment, where deltaic sediment is deposited rapidly, the sediment builds up pore-water pressures and could liquefy under extreme low tide conditions or ground shaking during an earthquake, because of low static shear strength. Thus, while ground shaking is one of the most common triggering mechanisms for submarine slope failures, a close relationship has been demonstrated between coastal landslides and extreme low tides (Thomson and others, 2001; Kulikov and others, 1998).

One of the principal triggering mechanisms for slope instability in southeastern Alaska is ground shaking associated with earthquakes. Slope failures can occur immediately during an earthquake, but they also frequently occur after shaking stops, due to creep, reduction of shear stress, or 
an increase in pore pressure (Nadim, 2012). The updated probabilistic seismic hazard maps for Alaska (Wesson and others, 2007) indicate that for the Yakutat Bay area the values for peak ground acceleration (PGA), with a 2 percent probability of exceedance in 50 years, range from $0.5 \mathrm{~g}$ to $0.7 \mathrm{~g}$, where $g$ is gravitational acceleration. Slope-stability analyses performed for fjords in Norway, an environment similar to southeastern Alaska, showed that much smaller values of PGAs are sufficient to trigger submarine slides even on gentle $3^{\circ}$ to $4^{\circ}$ slopes (Lacasse and others, 2013). While it is known that earthquakes have triggered major submarine mass movements in many places around the world (Mather and others, 2014; Lastras and others, 2013; Lee and others, 2006; Hance, 2003; Kulikov and others, 1998), site-specific slope-stability analyses that integrate geophysical, geological, and geotechnical data are required to adequately assess slope-stability hazards and their potential contribution to tsunami hazards.

\section{HYPOTHETICAL LANDSLIDE TSUNAMI SOURCES}

In addition to the hypothetical tectonic scenarios, we consider several landslide scenarios that could generate waves potentially hazardous to Yakutat. Yakutat Bay has a long history of underwater landslides. The second 1899 earthquake on September 10 (see "Earthquake and Tsunami History" section) had intense and prolonged ground shaking, which resulted in extensive changes in configuration of the shoreline (Yehle, 1979). According to Tarr and Martin (1912) there were two large submarine landslides - one along the south end of the Khantaak Island (A in fig. 11), and the other at the northern end of the island (B in fig. 11). Yehle's (1979) engineering-geologic study of the Yakutat area concluded that both slide areas were locations of rapid deposition of loose, sandy beach sediments, which are unstable during earthquakes.

The $\mathrm{M}_{\mathrm{S}} 7.9$ earthquake of July 10, 1958, was strongly felt in Yakutat (Yehle, 1979; Lander, 1996). The most complete account of the earthquake's effects in the Yakutat area is

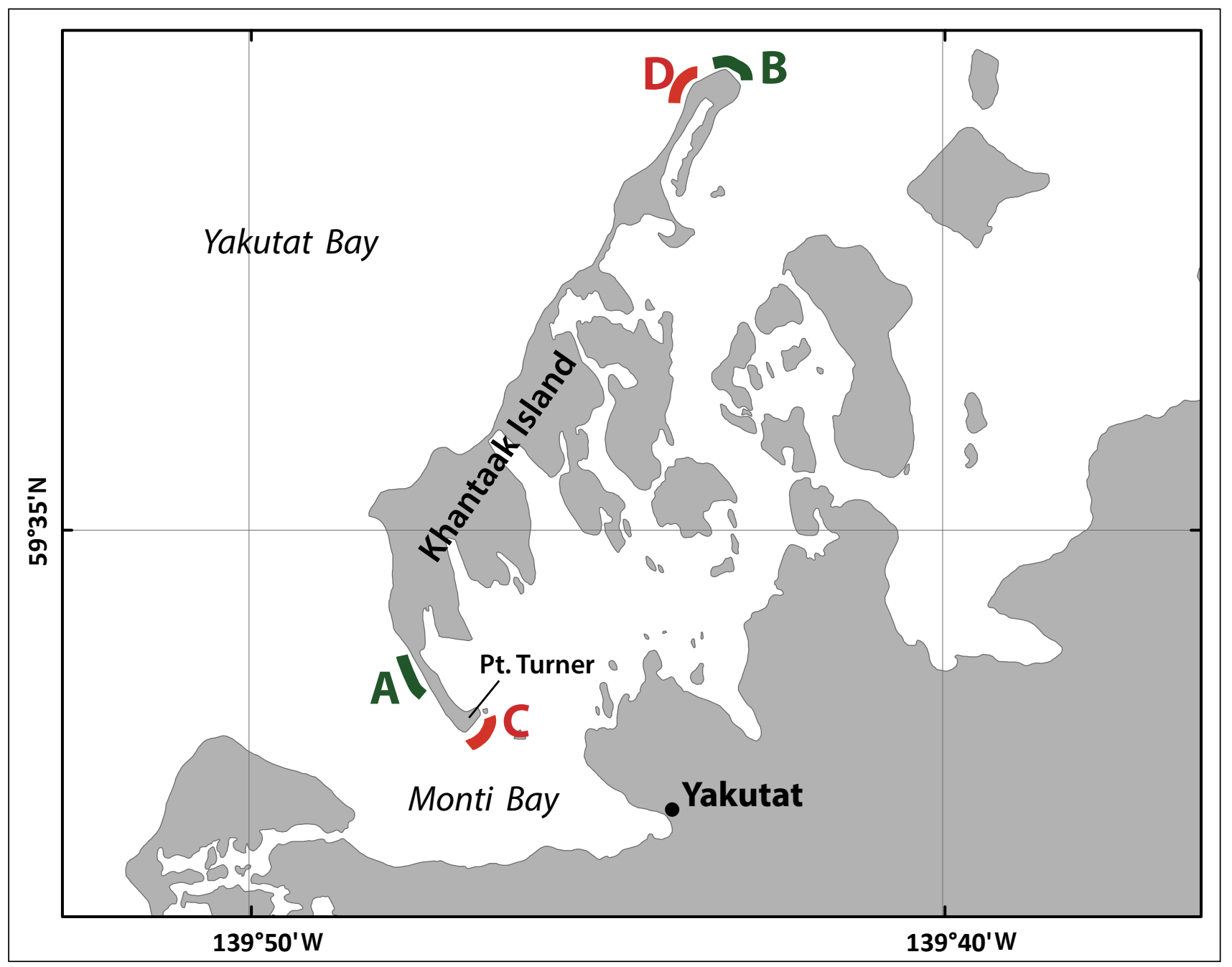

Figure 11. Detailed map of Khantaak Island in Yakutat Bay, showing locations of observed underwater slides during previous earthquakes: A-1899, B-1899, C-1958 and 1964, and D-1958. 
given in Davis and Sanders (1960). Yehle (1979) notes that Khantaak Island again experienced two large submarine landslides - one at the southern end of the island, at Point Turner ( $\mathrm{C}$ in fig. 11), and the other at the northern end of the island (D in fig. 11). It was suggested that the slides occurred at the same areas of rapid sediment deposition that slid during the earthquakes of 1899 . The slide at the southern end of the island was estimated to be at least $500,000 \mathrm{~m}^{3}(653,975$ $\mathrm{yd}^{3}$ ), involving shoreline slumping and recession of about

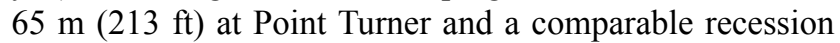
of the submarine slope, as indicated by a post-earthquake hydrographic survey. The slide caused a wave estimated to be 5-7 $\mathrm{m}(16-23 \mathrm{ft})$ high that killed three people who were berry picking at Khantaak Island at the time of the earthquake. The 1958 hydrographic survey of the area performed shortly after the earthquake discovered two knolls at the bottom of the bay, off Point Turner, which were not present in a previous survey in 1941 (Jordan, 1962). The conclusion was that these knolls were constructed of the sediments slumped from Point Turner.

The Great Alaska Earthquake of March 27, 1964, was strongly felt throughout the Yakutat area, with rolling and swaying ground motion that lasted about 6 minutes. A single wave was observed in Monti Bay during the earthquake. Roiled and muddy water was reported in the bay, and slumping of a beach was observed near Point Turner (fig. 11). These observations suggest the possibility that an underwater landslide occurred at the southern end of Khantaak Island, probably in the same area where previous slides were triggered by the 1899 and 1958 earthquakes (fig. 2) (Plafker and others, 1969).

Yakutat Bay is in the northeastern Gulf of Alaska, a tectonically active coastal region that transports sediment from land to the ocean (Swartz and others, 2015; Jaeger and Kramer, 2014; Elmore and others, 2013; Pavlis and others, 2012; Goff and others, 2012; Hallet and others, 1996). The combination of high sedimentation rates, seismic activity, and documented history of previous landslides in the region provides the grounds for considering future landslides in the area as potential sources of tsunami waves that could impact Yakutat. Figure 12 presents shaded bathymetry maps of Monti Bay, on which we placed hypothetical landslide sources along a steep slope in areas that have not collapsed in the past, based on the assumption that the material properties are uniform for this entire area, that is, the sediment delivered to Yakutat Bay by glacial rivers is fine grained, unconsolidated, and easily loses strength during earthquakes. We assumed that the entirety of the steep underwater slope (dashed line in fig. 12),

Table 8. Hypothetical landslide scenarios used to model tsunami runup in Yakutat. Slide locations shown in figure 12.

\begin{tabular}{|c|l|c|c|}
\hline Scenario & Description & $\begin{array}{c}\text { Volume } \\
\left(\text { million } \mathbf{~}^{\mathbf{3}} \text { ) }\right.\end{array}$ & $\begin{array}{c}\text { Maximum slide } \\
\text { thickness }(\mathbf{m})\end{array}$ \\
\hline 11 & Western slide & 3 & 26 \\
\hline 12 & Eastern slide & 0.5 & 23 \\
\hline 13 & Central slide & 2.9 & 33 \\
\hline 14 & Town slide & 2 & 35 \\
\hline
\end{tabular}

parts of which slid during previous earthquakes, is prone to the same type of slope failures under seismic loading. We used the estimated volume of $500,000 \mathrm{~m}^{3}\left(653,975 \mathrm{yd}^{3}\right)$ for the 1958 slide off the southern end of Khantaak Island as a reference value. After determining potential slide locations and defining the failure surfaces to constrain slide volumes, we constructed four hypothetical slide scenarios. Table 8 summarizes the landslide tsunami scenarios for Yakutat, and figures $12 \mathrm{a}$ and $12 \mathrm{~b}$ show locations and thicknesses of the slides. Unfortunately, there are no geotechnical data or local slope-stability analyses that could be used to better constrain the parameters of these potential underwater slides.

Although underwater slides occurred repeatedly at the northern end of Khantaak Island (fig. 11), we do not consider potential slides in that area because the community of Yakutat is well protected from waves that could originate there. The energy of the waves generated at the northern tip of the island would be directed mostly to the north, and the waves would be scattered by multiple islands before they reach Monti Bay (fig. 11).

\section{MODELING RESULTS}

\section{RESULTS OF HYPOTHETICAL TSUNAMI SCENARIOS}

We performed numerical calculations for all of the hypothetical scenarios described above (tables 3 and 8). For each of the ten tectonic scenarios, we modeled the water dynamics for each grid level listed in table 2, and then computed the extent of inundation and flow depths in the Yakutat highresolution grid. For landslide scenarios 11-14, all calculations were performed using the Yakutat high-resolution grid, as the landslide tsunami sources are located within this grid.

\section{Tectonic scenarios}

First we present the results of simulating the tectonic tsunami waves (fig. 13). The first group of tectonic sources consists of scenarios 1-2, in which the hypothetical rupture is based on the models of the 1964 rupture combined with rupture of the Yakataga-Yakutat segment. The second group comprises scenarios 3-7, in which the earthquake source is built using various slip distributions on the megathrust between segments SH and YY (fig. 3). The third group consists of scenarios 8-10, which are the near-field hypothetical earthquakes in the area of Yakutat Bay.

The modeling results suggest that tsunami sources built on the 1964 rupture models have only a moderate impact on Yakutat. The inundation area for these scenarios does not extend far beyond the MHHW in most areas. This result is also supported by observations of the 1964 tsunami at Yakutat, when several waves were observed during and after the earthquake, but none reached above extreme high water level or caused any damage (Plafker and others, 1969). In the second group of scenarios, scenario 5 predicts the largest inundation area. According to this scenario, the Yakutat village subdivision (the area between the first and second streets) would be flooded, as well 


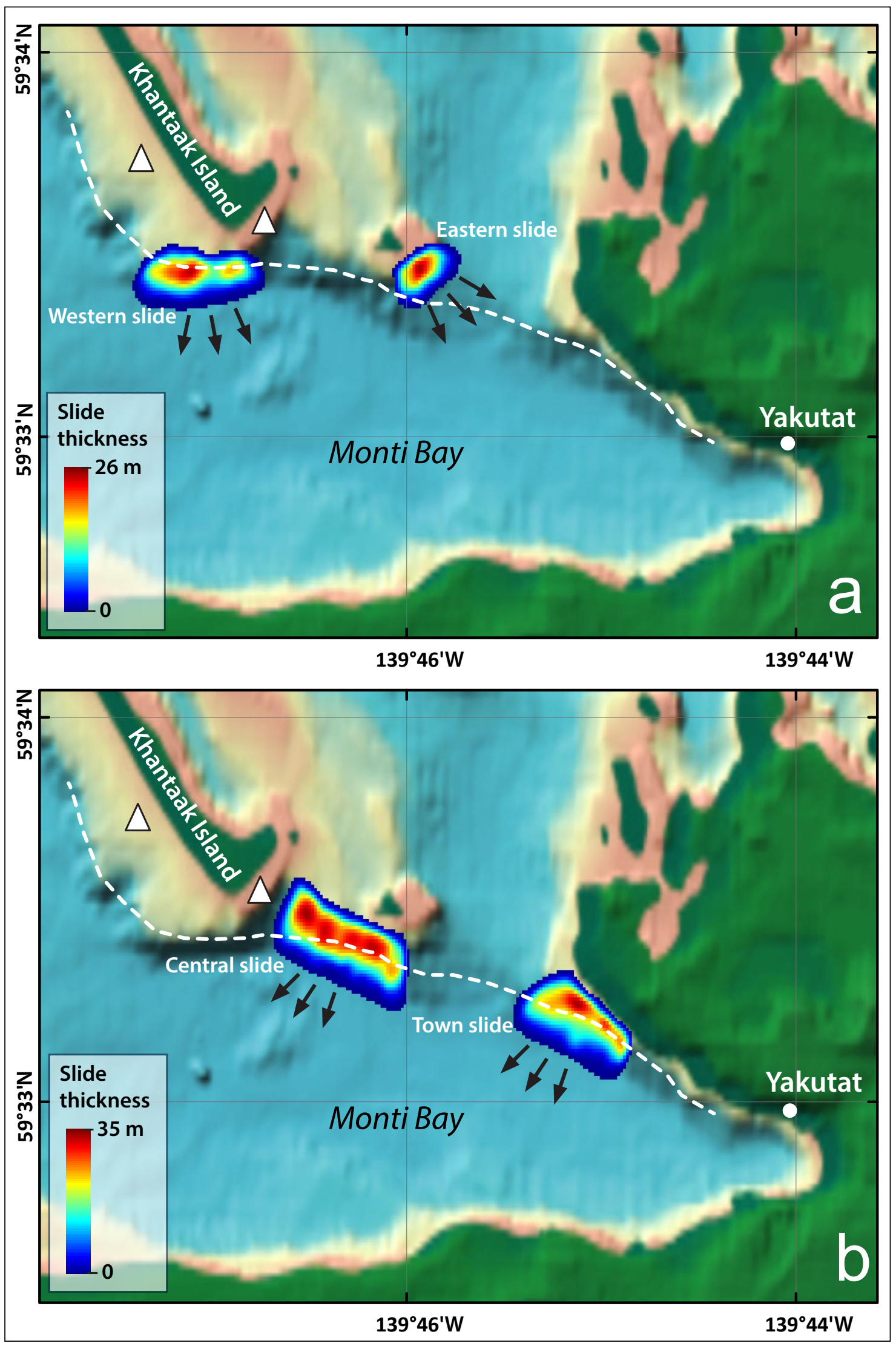

Figure 12. Shaded-relief bathymetry maps of Monti Bay. A steep underwater slope extending from the southwestern tip of Khantaak Island to the head of Monti Bay is shown by a white dashed line. The approximate locations of known slides are indicated by triangles. Locations and initial landslide thicknesses are shown in the upper plot (a) for scenarios 11 and 13, and in the lower plot (b) for scenarios 12 and 14. Black arrows indicate the direction of the tsunami energy propagation for each landslide scenario. 
as the area adjacent to the pier at the Ocean Cape industrial subdivision. In the third group of scenarios, the largest inundation zone results from scenario 8 . Scenarios 5 and 8 both result in about the same extent of inundation at the head of Monti Bay, at Savoy Beach Park, and at the dock where the tidal gauge is located. Overall, scenario 5 predicts the largest inundation among all considered scenarios. The hypothetical wave might travel farther inland and inundate locations that were not inundated during the 1964 tsunami, and represents the worst-case scenario for the community of Yakutat. We note that although the occurrence of a Tohoku-type event such as in scenario 5 is possible, the available geologic evidence suggests that repeated 1964-type events might be a more realistic estimate of future earthquake displacements. The composite inundation line for all tectonic scenarios - the Yakutat tsunami inundation map — is presented in figure 13.

Tsunami flow depth (depth of water over previously dry land) is an important indicator of potential damage, and must be differentiated from runup height (maximum elevation reached by tsunami waves) (Synolakis and Bernard, 2006). Thus, in addition to the computed tsunami inundation extents, we also show the maximum composite flow depth from all tectonic scenarios (fig. 13). For each scenario, the maximum flow depth is calculated by subtracting the post-earthquake DEM from the maximum tsunami wave height over the previously dry land. The maximum composite flow depth in each grid point is the largest value among all scenarios. We stress that the tsunami generated according to the worst-case Tohoku-type scenario 5 is much more devastating compared to tsunamis simulated by other scenarios, and hence the composite inundation from all scenarios is essentially equal to the inundation due to scenario 5 , which is considered to be the worst-case scenario. For easier visual reference, we indicate the values of $0.5 \mathrm{~m}(1.6 \mathrm{ft})$, which approximately corresponds to knee height, and $2 \mathrm{~m}(6.5 \mathrm{ft})$, which is just deep enough to drown most people. Results of the numerical calculations of the flow depths can provide some essential and site-specific guidelines for evacuation planning.

\section{Landslide scenarios}

The effects of landslide tsunami scenarios are site-specific. Figure 14 presents composite flow depths calculated for all landslide scenarios, 11-14 (table 8 and fig. 12). It shows that the coastal areas most affected by these scenarios are either adjacent to the landslide-generation areas, or across the bay from them. At the same time, there are areas that have not experienced any tsunami runup. Black arrows in figure 12 show the direction of tsunami energy propagation for each individual landslide scenario. If a future landslide occurs along the southern side of Khantaak Island (scenario 11) similar to the slides of 1899, 1958, and 1964 (figs. 2 and 11), then the majority of the tsunami energy will be directed across the bay toward the southern shore of Monti Bay, resulting in flow depths up to $7 \mathrm{~m}(23 \mathrm{ft})$. Scenarios 12 and 13 will result in similar effects along the same shore. If a future slide is generated along the northern shore of Monti Bay (scenario 14), then the areas most affected by the waves will be those along the shoreline next to the landslide area, where Yakutat Cold Storage and the sewage plant are located.
To forecast which part of the underwater slope in Monti Bay will be more likely to fail during the next earthquake, and what volume of material could be involved, site-specific geotechnical information and local slope-stability analyses are needed to better constrain the potential submarine slides. Because this information is not available to adequately assess underwater slope-stability hazards in Monti Bay, we emphasize that all considered landslide tsunami scenarios are hypothetical, both in terms of location and volume. At the same time, the previous history of multiple slides off Khantaak Island indicates that these events are likely to happen again during future earthquakes. Because we cannot exclude any specific part of the bay from being a potential landslide source, we assume that the entire coastline of Monti Bay is vulnerable to tsunami waves. To provide more meaningful information on landslide tsunami hazard in the bay, we developed a procedure for estimating potential flow depths for landslide-generated tsunamis for the entire coastline of Monti Bay. This involves the following steps:

1. We develop hypothetical landslide scenarios (table 8) as described in the previous section, and calculate the composite flow depths for all landslide scenarios (fig. 14).

2. We analyze the composite landslide flow depth map (fig. 14). Landslides produce much shorter waves and more focused tsunami energy flux than earthquakes, therefore landslide tsunami effects along the coast are not uniform. Areas with high flow depth values could be just a hundred feet away from areas that are not affected at all. Therefore, to fill in the gaps, for each section of coast inundated by the landslide tsunamis we find the maximum value of runup and assign this value to the entire section. The result is the generalized landslide tsunami hazard map shown in figure 15, in which oval shapes represent landside-generation areas and arrows indicate the main direction of tsunami energy propagation.

3. We calculate projections of extrapolated runup values onto the coastal topography and produce a map of projected flow depths for landslide scenarios (fig. 16).

\section{Composite inundation}

Map sheet 1 shows the maximum composite calculated extent of inundation for all scenarios, and the maximum composite flow depths over dry land. This map superimposes the tectonic tsunami inundation map (fig. 13) with the projected landslide tsunami inundation map (fig. 16) by selecting the maximum of the two values for flow depth for each grid point.

\section{TIME SERIES AND OTHER NUMERICAL RESULTS}

To provide emergency managers with the tools they need to assess the tsunami hazard in Yakutat, we supplement the inundation maps with time series of the modeled water level and velocity dynamics at certain locations around Monti Bay, and also in Sawmill, Puget, and Shipyard coves. The arrival time of the first wave, the maximum wave amplitude, and 


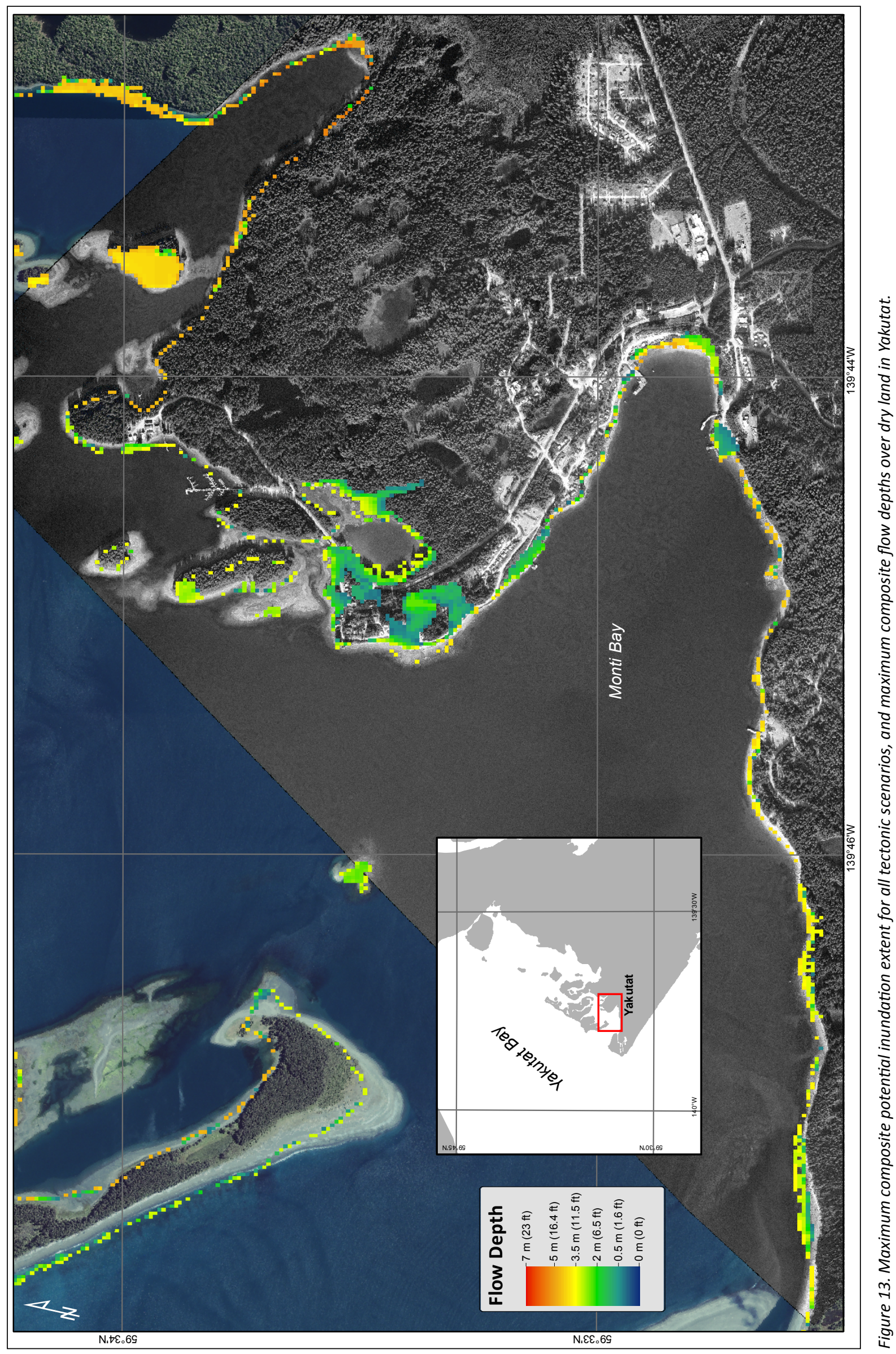




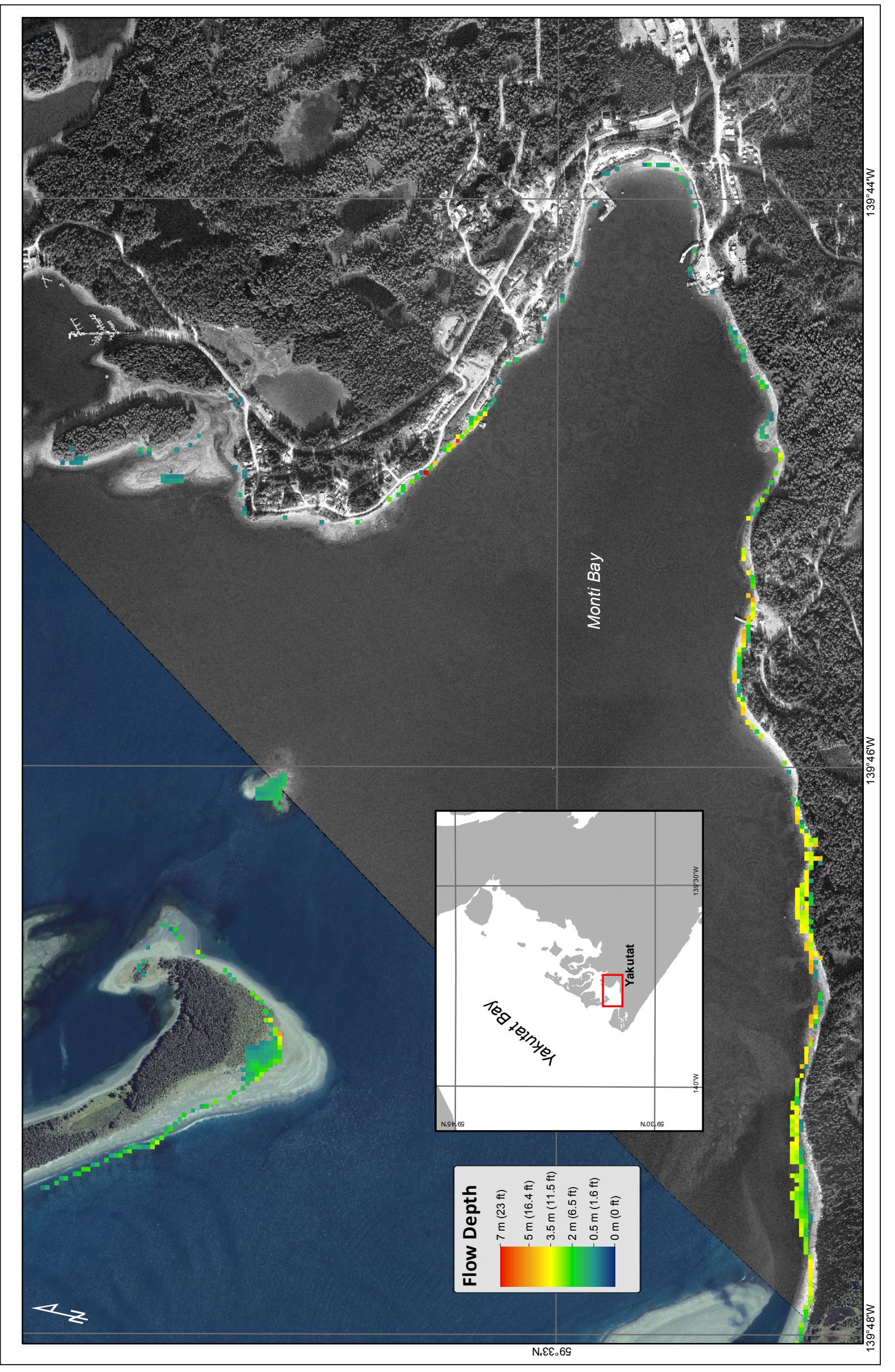

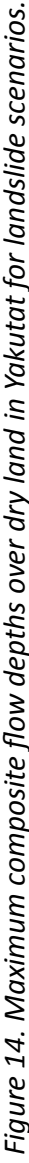




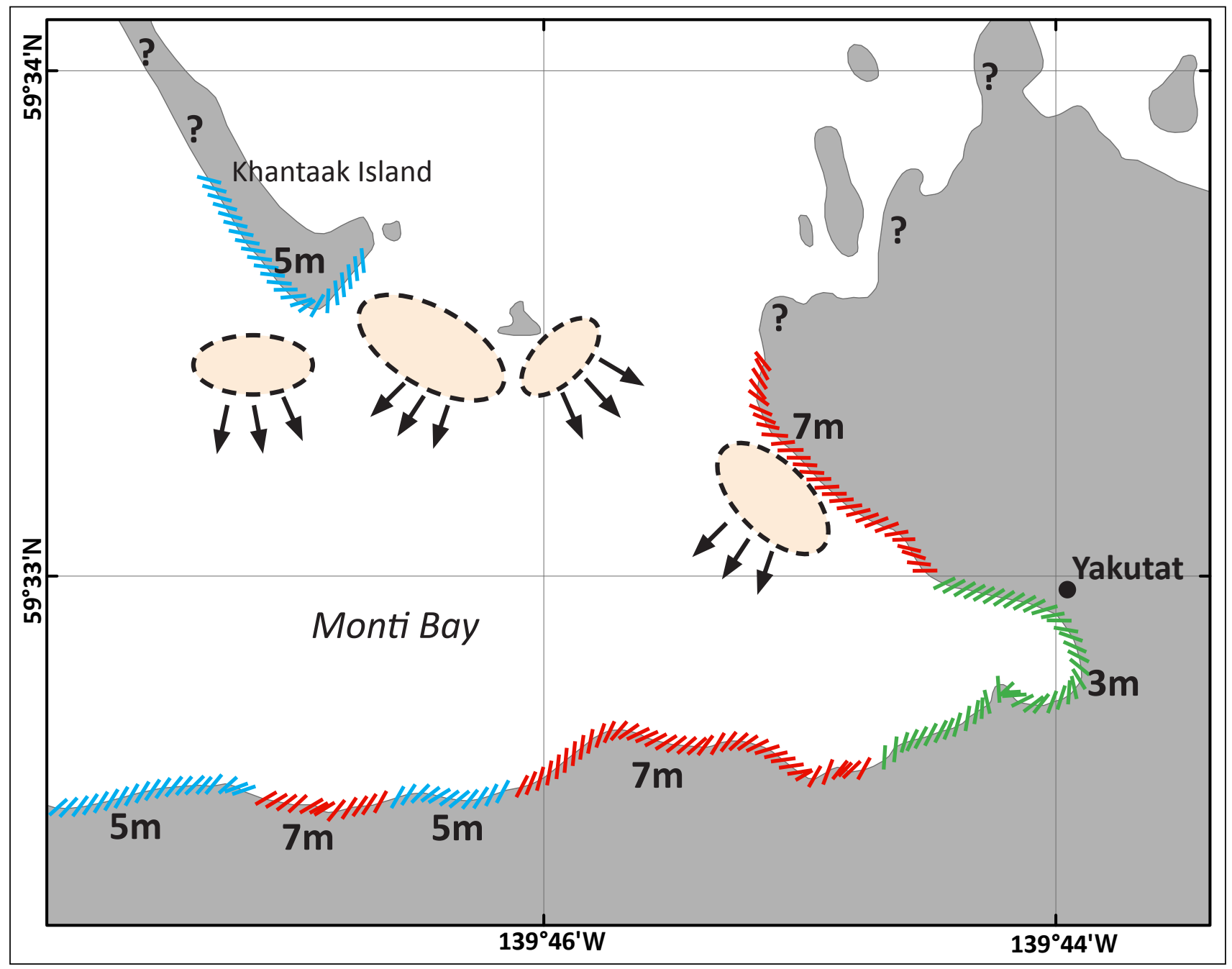

Figure 15. Generalized composite hazard map for landslide scenarios. Oval shapes are landslide-generation areas; arrows indicate the main direction of tsunami energy propagation. Numbers show expected flow depths in meters; queried segments of the coastline were not affected by landslide scenarios simulated in this study.

the duration of wave action are important factors that should be considered by emergency managers during evacuation planning. Appendix A contains plots of sea level and velocity time series for selected scenarios at critical locations. For each location shown by a number in figure A-1, we plot the sea level and water velocity in figures A-2 (scenarios 1-5) and A-3 (scenarios 6-10). The zero time corresponds to the epicenter origin time. Elevations of onshore locations and values of ocean depth at offshore locations are based on the pre-earthquake MHHW datum. Because the velocity magnitude is calculated as water flux divided by water depth, the velocity value can have large uncertainties when the water depth is small. In the plots provided, velocity is computed only where the water depth is greater than $0.3 \mathrm{~m}(1 \mathrm{ft})$.

Analysis of the time series plots shows that the hypothetical Tohoku-type $\mathrm{M}_{\mathrm{W}} 9.0$ events in the Gulf of Alaska (scenarios 5 and 6) result in the largest wave amplitudes and velocity currents at almost all locations. The $\mathrm{M}_{\mathrm{W}} 7.7$ Otmeloi fault rupture (scenario 8), a local hypothetical scenario in the area of Yakutat Bay, could also generate a devastating wave with the potential to impact the city of Yakutat. Other scenarios for local faulting should also be examined in the future as new information about the tectonic architecture is published. Another critical piece of information derived from the time series plots is that water-level oscillations continue for at least 12 hours. This means that even in the case of an earthquake at low tide, these oscillations will be superimposed with the rising tide later, resulting in inundation of low-lying areas that were not flooded during low tide.

One of the important factors in tsunami hazard assessment for any coastal community is the arrival time of the first wave. The time series plots demonstrate that for the hypothetical events in the Gulf of Alaska, with rupture areas that include segments from KI to YY (scenario 6 and fig. 3), the first wave arrives to Yakutat about an hour after the earthquake. For scenario 7, with a source function that spreads over segments SH and SEM (fig. 3), the arrival time of the first wave is about 2 hours. This means that the Yakutat population will have up to an hour for evacuation if the tsunami is generated by a megathrust earthquake in the Gulf of Alaska. However, near-field hypothetical earthquakes in the area of Yakutat Bay (scenarios 8-10) are capable of producing 


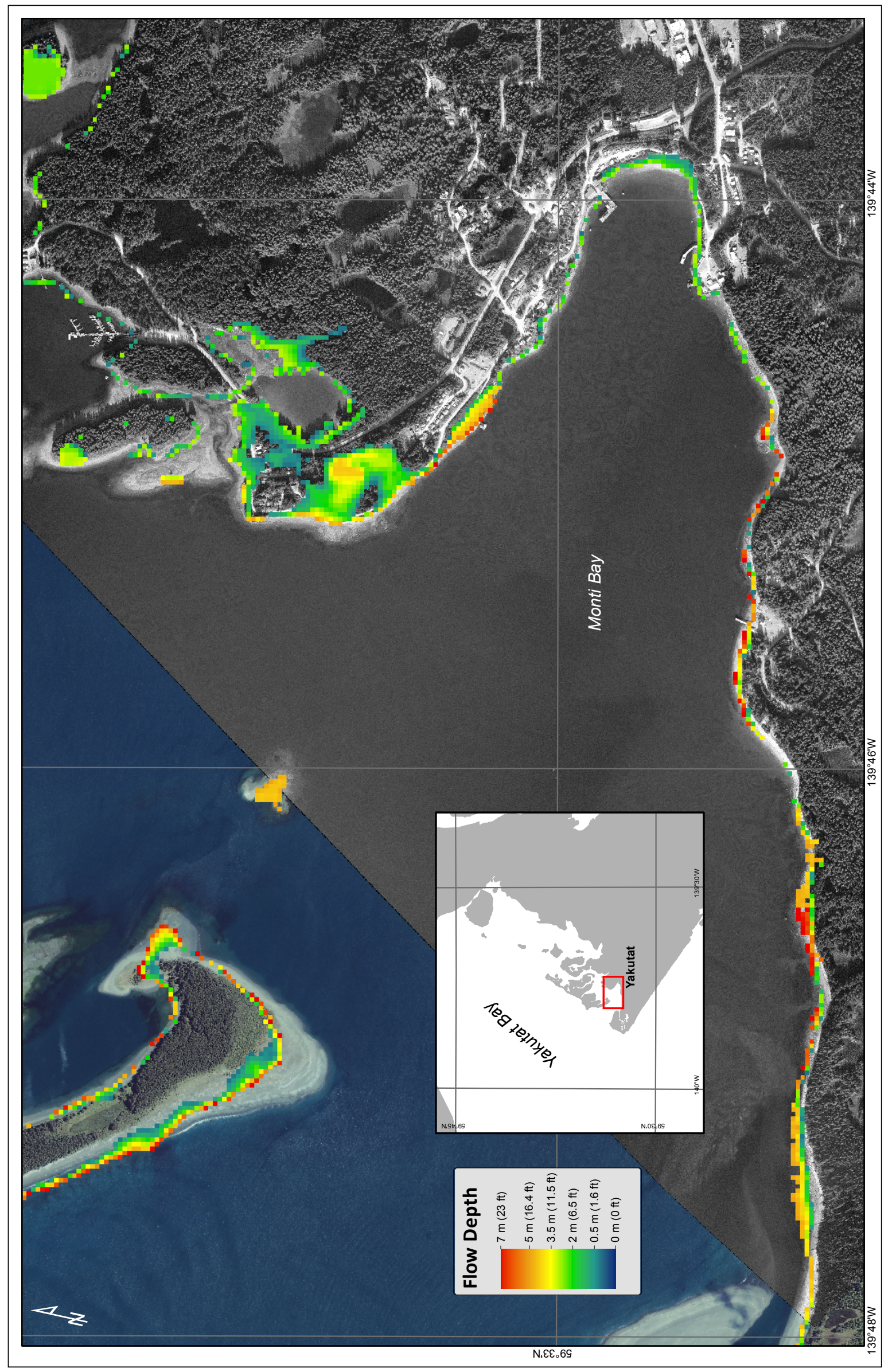


waves that reach onshore locations in Yakutat between 10 and 30 minutes after the earthquake. Recognizing that the arrival time characterizes the vulnerability of a community to tsunami hazard has special significance for local emergency officials in evacuation planning. For example, the water level at the head of Monti Bay (point 12 in fig. A-1) reaches 4.5 $\mathrm{m}(14.8 \mathrm{ft})$ about 1 hour 10 minutes after the Gulf of Alaska earthquake described in scenario 6. However, the waves generated by the local Otmeloi fault rupture (scenario 8) will reach an amplitude of $3 \mathrm{~m}(9.8 \mathrm{ft})$ at the same point only 10 minutes after the earthquake. This indicates that scenario 8 or other local source scenarios may present the most significant tsunami hazard for Yakutat due to combination of short arrival time and high amplitudes of tsunami waves.

\section{SOURCES OF ERRORS AND UNCERTAINTIES}

The hydrodynamic model used to calculate tsunami propagation and runup is a nonlinear, flux-formulated, shallow-water model (Nicolsky and others, 2011; Nicolsky, 2012). The model passed the verification and validation tests required for numerical codes used in production of tsunami inundation maps (Synolakis and others, 2007; NTHMP, 2012). The spatial resolution of the grid used to calculate tsunami inundation at Yakutat satisfies NOAA minimum recommended requirements for computation of tsunami inundation (NTHMP, 2010). However, while uncertainty in the cell elevation and cell bathymetry values affect the hydrodynamics of the model and contribute to horizontal uncertainty of the inundation line, no established practices exist to directly propagate the DEM uncertainty into the uncertainty of the inundation line (Hare and others, 2011). The current practice is to create an additional buffer area around the inundation line to use for hazard mitigation and decisions related to tsunami evacuation.

Because the initial condition in tsunami modeling is determined by the displacement of the seafloor, uncertainties in the source (earthquake) model remain the largest source of error in tsunami modeling efforts. When a tsunami is generated in the vicinity of the coast the direction of the incoming waves, their amplitudes, and times of arrival are determined by the initial displacements of the ocean surface in the source area because the distance to the shore is too small for the waves to disperse. Therefore, near-field inundation modeling results are especially sensitive to the fine structure of the tsunami source. The modeling process is highly sensitive to errors when the complexity of the source function is combined with its proximity to the coastal zone.

During development of the tsunami inundation maps, spatially averaged ground subsidence/uplift models were assumed for Yakutat. However, during a potential earthquake, soil compaction in areas of unconsolidated deposits in the coastal zone might occur and the tsunami inundation could extend farther landward. Finally, the horizontal resolution of the grid used for inundation modeling is about $16 \mathrm{~m}(52.5 \mathrm{ft})$. This resolution is sufficient to describe major relief features, but small topographic features, buildings, and other facilities cannot be resolved accurately by the existing model.

\section{SUMMARY}

We present the results of numerical modeling of tectonic and landslide-generated tsunami waves for the community of Yakutat in southeastern Alaska. We emphasize that each of the scenarios considered is geologically reasonable and presents potential hazards to the community. The available geologic evidence indicates that repeated 1964-type events provide the most realistic estimate of future earthquake displacements, but the occurrence of Tohoku-type events is possible. Thus scenario 5, based on a Tohoku-type source mechanism, is considered the worst-case scenario for the community of Yakutat. Additionally, the short arrival time and high tsunamiwave amplitudes estimated for a local earthquake along the Otmeloi fault (scenario 8) or other proximal structures present a significant tsunami hazard for Yakutat.

The maps that are part of this report have been completed using the best information available and are believed to be accurate; however, their preparation required many assumptions. We have considered several tsunami scenarios and have provided an estimate of maximum credible tsunami inundation. Actual conditions during a tsunami event could vary from those considered, so the report's accuracy cannot be guaranteed. The limits of inundation presented should only be used as a guideline for emergency planning and response action. Actual areas inundated will depend on specifics of earth deformation, on-land construction, and tide level, and could differ from areas shown on the map. The information on this map is intended to assist state and local agencies in planning emergency evacuation and tsunami response actions in the event of a major tsunamigenic earthquake. These results are not intended for land-use regulation or buildingcode development.

\section{ACKNOWLEDGMENTS}

This project was supported by the National Oceanic and Atmospheric Administration (NOAA) under Reimbursable Services Agreement ADN 0931000 with the State of Alaska's Division of Homeland Security and Emergency Management (a division of the Department of Military and Veterans Affairs). Some of the research in this report is sponsored by the Cooperative Institute for Alaska Research with funds from NOAA under cooperative agreement NA08OAR4320751 with the University of Alaska Fairbanks. Numerical calculations for this work were supported by a grant of High Performance Computing (HPC) resources from the Arctic Region Supercomputing Center (ARSC) at the University of Alaska Fairbanks. We thank Sean Gulick for his incredibly comprehensive review that helped to improve the report, and also an anonymous reviewer for a number of insightful comments and suggestions. 


\section{REFERENCES}

Alaska Department of Commerce, Community, and Economic Development, Division of Community and Regional Affairs (DCCED/DCRA), 2013, Community Database Online. https://www.commerce.alaska.gov/web/dcra/

Arakawa, Akio, and Lamb, V.R., 1981, A potential enstrophy and energy conserving scheme for the shallow water equations: Monthly Weather Review, v. 109, no. 1, p. 18-36. http://journals.ametsoc.org/toc/mwre/109/1

Assier-Rzadkiewicz, S., Mariotti, C., and Heinrich, P., 1997, Numerical simulation of submarine landslides and their hydraulic effects: Journal of Waterway, Port, Coastal, and Ocean Engineering, v. 123, no. 4, p. 149-157. doi:10.1061/(ASCE)0733-950X(1997)123:4(149)

Bornhold, B.D., Thomson, R.E., Rabinovich, A.B., Kulikov, E.A., and Fine, I.V., 2001, Risk of landslide-generated tsunamis for the coast of British Columbia and Alaska, in Mahmoud, M., van Everdingen, R., and Carss, J., eds., An earth odyssey-Proceedings of the 54th Canadian Geotechnical Society Conference: Richmond, B.C., Bitech Publishers, Ltd., p. 1,450-1,454.

Caldwell, R.J., Taylor, L.A., Eakins, B.W., Carignan, K.S., and Collins, S.V., 2012, Digital elevation models of Juneau and Southeast Alaska-Procedures, data sources and analysis: National Geophysical Data Center, NOAA Technical Memorandum NESDIS NGDC-53, 66 p.

Caldwell, R.J., Eakins, B.W., and Lim, E., 2011, Digital elevation models of Yakutat, Alaska-Procedures, data sources and analysis: National Geophysical Data Center, NOAA Technical Memorandum NESDIS NGDC-41, 29 p.

Carver, G.A., and Plafker, George, 2008, Paleoseismicity and neotectonics of the Aleutian subduction zone-An overview, in Freymueller, J.T., Haeussler, P.J., Wesson, R.L, and Ekström, G., eds., Active tectonics and seismic potential of Alaska: American Geophysical Union Geophysical Monograph 179, p. 43-63.

Chapman, J.B., Pavlis, T.L., Gulick, S.P.S., Berger, A.L. Lowe, Lindsay, Spotila, James, Bruhn, R.L., Vorkink, Michael, Koons, Peter, Barker, Adam, Picornell, Carlos, Ridgway, Ken, Hallet, Bernard, Jaeger, John, and McCalpin, James, 2008, Neotectonics of the Yakutat collision-Changes in deformation driven by mass redistribution, in Freymueller, J.T., Haeussler, P.J., Wesson, R.L., and Ekström, Göran, eds., Active tectonics and seismic potential of Alaska: Washington, DC, American Geophysical Union, Geophysical Monograph Series, p. 65-81. doi:10.1029/179GM04

Chapman, J.B., Pavlis, T.L., Bruhn, R.L., Worthington, L.L., Gulick, S.P.S., and Berger, A.L., 2012, Structural relationships in the eastern syntaxis of the St. Elias orogen, Alaska: Geosphere, v. 8, no. 1, p. 105-126. doi:10.1130/ GES00677.1

Christensen, D.H., and Beck, S.L., 1994, The rupture process and tectonic implications of the Great 1964 Prince William Sound Earthquake: Pure and Applied Geophysics, v. 142 , no. 1 , p. 29-53.
Davis, T.N., and Sanders, N.K., 1960, Alaska earthquake of July 10, 1958 - Intensity distribution and field investigation of northern epicentral region: Bulletin of the Seismological Society of America, v. 50, no. 2, p. 22,252.

Doser, D.I., and Lomas, Rodolfo, 2000, The transition from strike-slip to oblique subduction in southeastern Alaska from seismological studies: Tectonophysics, v. 316, no. 1-2, p. 45-65.

Dunbar, P.K., and Weaver, C.S., 2008, U.S. states and territories national tsunami hazard assessment-Historical record and sources for waves: Technical Report, National Oceanic and Atmospheric Administration and U.S. Geological Survey, 59 p. http://nthmp.tsunami.gov/docum ents/Tsunami_Assessment_Final.pdf

Eberhart-Phillips, D., Christensen, D.H., Brocher, T.M., Hansen, Roger, Ruppert, N.A., Haeussler, P.J., and Abers, G.A., 2006, Imaging the transition from Aleutian subduction to Yakutat collision in central Alaska, with local earthquakes and active source data: Journal of Geophysical Research, v. 111, no. B11, p. 303. doi:10.1029/2005JB004240

Elliott, J.L., Larsen, C.F., Freymueller, J.T., and Motyka, R.J., 2010, Tectonic block motion and glacial isostatic adjustment in southeast Alaska and adjacent Canada constrained by GPS measurements: Journal of Geophysical Research, v. 115, no. B9, p. 407. doi:10.1029/2009JB007139

Elliott, J.L., Freymueller, J.T., and Larsen, C.F., 2013, Active tectonics of the St. Elias orogen, Alaska, observed with GPS measurements: Journal of Geophysical Research, Solid Earth, v. 118, no. 10, p. 5,625-5,642. doi:10.1002/ jgrb. 50341

Elmore, C.R., Gulick, S.P.S., Willems, Bryce, and Powell, Ross, 2013, Seismic stratigraphic evidence for glacial expanse during glacial maxima in the Yakutat Bay region, Gulf of Alaska: Geochemistry, Geophysics, Geosystems, v. 14, no. 4, p. 1,294-1,311. doi:10.1002/ggge.20097

Enet, Francois, and Grilli, Stephan T., 2007, Experimental study of tsunami generation by three-dimensional rigid underwater landslides: Journal of Waterway, Port, Coastal and Ocean Engineering, v. 133, no. 6, p. 442-454.

Ferris, Aaron, Abers, G.A., Christensen, D.H., and Veenstra, Elizabeth, 2003, High resolution image of the subducted Pacific(?) plate beneath central Alaska, 50-150 km depth: Earth and Planetary Science Letters, v. 214, no. 3-4, p. 575-588. doi:10.1016/S0012-821X(03)00403-5

Fine, I.V., Rabinovich, A.B., Kulikov, E.A., Thomson, R.E., and Bornhold, B.D., 1998, Numerical modeling of landslide-generated tsunamis with application to the Skagway Harbor tsunami of November 3, 1994, in Proceedings of International Conference on Tsunamis: Paris, France, May 26-28, 1998, Commissariat à l'Energie Atomique (CEA), p. 211-223.

Fletcher, H.J., and Freymueller, J.T., 2003, New constraints on the motion of the Fairweather fault, Alaska, from GPS observations: Geophysical Research Letters, v. 30, no. 3, p. 1,139. doi:10.1029/2002GL016476

Freund, L.B., and Barnett, D.M., 1976, A two-dimensional analysis of surface deformation due to dip-slip faulting: 
Bulletin of the Seismological Society of America, v. 66, no. 3, p. 667-675.

Fujii, Yushiro, Satake, Kenji, Sakai, Shin'ichi, Shinohara, Masanao, and Kanazawa, Toshihiko, 2011, Tsunami source of the 2011 off the Pacific coast of Tohoku earthquake: Earth Planets Space, v. 63, p. 815-820.

Gesch, Dean B., and Wilson, Robert, 2002, Development of a seamless multisource topographic/bathymetric elevation model of Tampa Bay: Marine Technology Society Journal, v. 35, no. 4, p. 58-64.

Goff, J.A., Lawson, D.E., Willems, B.A., Davis, Marcy, and Gulick, S.P.S., 2012, Morainal bank progradation and sediment accumulation in Disenchantment Bay, Alaska-Response to advancing Hubbard Glacier: Journal of Geophysical Research, v. 117, no. F02, p. 31. doi:10.1029/2011JF002312

Gulick, S.P.S., Lowe, L.A., Pavlis, T.L., Gardner, J.V., and Mayer, L.A., 2007, Geophysical insights into the Transition fault debate-Propagating strike slip in response to stalling Yakutat block subduction in the Gulf of Alaska: Geology, v. 35, no. 8, p. 763-766. doi:10.1130/ G23585A.1

Gulick, S.P.S., Reece, R.S., Christenson, G.L., Van Avendonk, H.J.A., Worthington, L.L., and Pavlis, T.L., 2013, Seismic images of the Transition fault and the unstable Yakutat-Pacific-North American triple junction: Geology, v. 41, no. 5, p. 571-574. doi:10.1130/G33900.1

Haeussler, P.J., Lee, H.J., Ryan, H.F., Labay, K.A., Kayen, R.E., Hampton, M.A., and Suleimani, E.N., 2007, Submarine slope failures near Seward, Alaska, during the M9.2 1964 earthquake, in Lykousis, V., Sakellariou, D., and Locat, J., eds., Submarine mass movements and their consequences: Netherlands, Springer, Advances in Natural and Technological Hazards Research series, p. 269-278. doi:10.1007/978-1-4020-6512-5_28

Haeussler, P.J., Witter, R.C., and Wang, Kelin, 2015, Intertidal biological indicators of coseismic subsidence during the $\mathrm{M}_{\mathrm{W}} 7.8$ Haida Gwaii, Canada, earthquake, in 2012 Haida Gwaii and 2013 Craig earthquakes at the Pacific-North America plate boundary (British Columbia and Alaska): Bulletin of the Seismological Society of America, v. 105, no. 2B, p. 1,265-1,279. doi:10.1785/0120140197

Hallet, B., Hunter, L., and Bogen, J., 1996, Rates of erosion and sediment evacuation by glaciers - A review of field data and their implications: Global and Planetary Change, v. 12 , no. 1-4, p. 213-235.

Hamilton, Sarah, and Shennan, Ian, 2005, Late Holocene great earthquakes and relative sea-level change at Kenai, southern Alaska: Journal of Quaternary Science, v. 20, no. 2, p. 95-111.

Hampton, M.A., Lemke, R.W., and Coulter, H.W., 1993, Submarine landslides that had a significant impact on man and his activities, Seward and Valdez, Alaska, in Schwab, W.C., Lee, H.J., and Twichell, D.C., eds., Submarine Landslides-Selected Studies in the U.S. Exclusive Economic Zone: U.S. Geological Survey Bulletin 2002, p. $123-134$.
Hance, J.J., 2003, Submarine slope stability [based on M.S. Engineering Thesis, "Development of a database and assessment of seafloor slope stability based on published literature" for University of Texas at Austin by J.J. Hance]: Project report prepared for the Minerals Management Service, MMS Project 421, Offshore Technology Research Center Library Number 8/03B121, 269 p.

Hare, R., Eakins, B., Amante, C., and Taylor, L., 2011, Modeling bathymetric uncertainty: Proceedings of the U.S. HYDRO 2011 conference, Tampa, FL, April 25-28, 2011.

Hayes, G.P., Wald, D.J., and Johnson, R.L., 2012, Slab 1.0-A three-dimensional model of global subduction zone geometries: Journal of Geophysical Research, v. 117, no. B1, 1 p., doi:10.1029/2011JB008524

Holdahl, S.R., and Sauber, Jeanne, 1994, Coseismic slip in the 1964 Prince William Sound earthquake - A new geodetic inversion: Pure and Applied Geophysics, v. 142, no. 1 , p. 55-82.

Holtkamp, Stephen, and Ruppert, Natalia, 2015, A high resolution aftershock catalog of the magnitude 7.5 Craig, Alaska, earthquake on 5 January 2013: Bulletin of the Seismological Society of America, v. 105, no. 2, p. 1,143-1,152. doi:10.1785/0120140179

Ito, Yoshihiro, Tsuji, Takeshi, Osada, Yukihito, Kido, Motoyuki, Inazu, Daisuke, Hayashi, Yutaka, Tsushima, Hiroaki, Hino, Ryota, and Fujimoto, Hiromi, 2011, Frontal wedge deformation near the source region of the 2011 Tohoku-Oki earthquake: Geophysical Research Letters, v. 38, no. 7. doi:10.1029/2011GL048355

Jaeger, J.M., and Kramer, Branden, 2014, A continental shelf sedimentary record of Little Ice Age to modern glacial dynamics - Bering Glacier, Alaska: Continental Shelf Research, v. 86, p. 141-156. doi:10.1016/j.csr.2013.03.011

James, T.S., Cassidy, J.F., Rogers, G.C., and Haeussler, P.J., 2015, [Introduction, Special Issue] 2012 Haida Gwaii and 2013 Craig earthquakes at the Pacific-North America plate boundary (British Columbia and Alaska), in 2012 Haida Gwaii and 2013 Craig earthquakes at the Pacific North America plate boundary (British Columbia and Alaska): Bulletin of the Seismological Society of America, v. 105, no. 2, p. 1,053-1,057. doi:10.1785/0120150044

Jiang, Lin, and LeBlond, P.H., 1992, The coupling of a submarine slide and the surface waves which it generates: Journal of Geophysical Research, v. 97, no. C8, p. 12,731-12,744. doi:10.1029/92JC00912

Jiang Lin, and LeBlond P.H., 1994, Three-dimensional modeling of tsunami generation due to a submarine mudslide: Journal of Physical Oceanography, v. 24, no. 3, p. 559-572.

Johnson, J.M., Satake, Kenji, Holdahl, S.R., and Sauber, Jeanne, 1996, The 1964 Prince William Sound earthquake-Joint inversion of tsunami waveforms and geodetic data: Journal of Geophysical Research, v. 101, no. B1, p. 523-532. doi:10.1029/95JB02806

Jordan, G.F., 1962, Redistribution of sediments in Alaskan bays and inlets: Geographical Review (American Geographical Society of New York), v. 52, no. 4, p. 548-558. 
Kanamori, Hiroo, 1970, The Alaska earthquake of 1964Radiation of long-period surface waves and source mechanism: Journal of Geophysical Research, v. 75, no. 26 , p. $5,029-5,040$.

Kirby, J.T., Shi, F., Nicolsky, D.J., and Misra, S., in process, The 27 April 1975 Kitimat, British Columbia submarine landslide tsunami-A comparison of modeling approaches: Submitted to Landslides (journal).

Koehler, R.D., 2013, Quaternary Faults and Folds (QFF): Alaska Division of Geological \& Geophysical Surveys Digital Data Series 3, http://maps.dggs.alaska.gov/qff/. doi:10.14509/24956.

Kulikov, E.A., Rabinovich, A.B., Fine, I.V., Bornhold, B.D., and Thomson, R.E., 1998, Tsunami generation by landslides at the Pacific coast of North America and the role of tides: Oceanology, v. 38, no. 3, p. 323-328.

Lacasse, Suzanne, Nadim, Farrokh, Vanneste, Maarten, L'Heureux, Jean-Sebastian, Forsberg, C.F., and Kvalstad, T.J., 2013, Case studies of offshore slope stability: Proceedings, Geo-Congress 2013, p. 2,369-2,408, doi:10.1061/9780784412787.228

Lander, J.F., 1996, Tsunamis affecting Alaska, 1737-1996: Boulder, CO, National Geophysical Data Center (NGDC), NOAA, Key to Geophysical Research Documentation, v. 31,195 p.

Lastras, Galderic, Amblas, David, Calafat, A.M., Canals, Miquel, Frigola, Jaime, Hermanns, R.L., Lafuerza, Sara, Longva, Oddvar, Micallef, Aaron, Sepúlveda, S.A., Vargas, Gabriel, De Batist, Marc, Van Daele, Maarten, Azpiroz, María, Bascuñán, Ignacio, DuHart, Paul, Iglesias, Olaia, Kempf, Philipp, and Rayo, Xavier, 2013, Landslides cause tsunami waves-Insights from Aysén Fjord, Chile [abst.]: Eos Transactions, American Geophysical Union, v. 94, no. 34, p. 297-298, doi:10.1002/2013EO340002

Lee, H.J., Ryan, Holly, Kayen, R.E., Haeussler, P.J., Dartnell, Peter, and Hampton, M.A., 2006, Varieties of submarine failure morphologies of seismically-induced landslides in Alaskan fjords: Norwegian Journal of Geology (Norsk Geologisk Tidsskrift), v. 86, no. 3, p. 221-230.

Leica Geosystems AG, 2002, GPS User Manual, Version 4, Leica Geosystems AG, Heerbrugg, Switzerland, 62 p.

Leonard, L.J., and Bednarski, J.M., 2015, The preservation potential of coastal coseismic and tsunami evidence observed following the $2012 \mathrm{M}_{\mathrm{W}} 7.8$ Haida Gwaii thrust earthquake, in 2012 Haida Gwaii and 2013 Craig earthquakes at the Pacific North America plate boundary (British Columbia and Alaska), Bulletin of the Seismological Society of America, v. 105, no. 2B, p. 1,280-1,289. doi:10.1785/0120140193

Ma, Gangfeng, Shi, Fengyan, and Kirby, J.T., 2012, Shockcapturing non-hydrostatic model for fully dispersive surface wave processes: Ocean Modelling, v. 43-44, p. 22-35. doi:10.1016/j.ocemod.2011.12.002

Ma, Gangfeng, Kirby, J.T., and Shi, Fengyan, 2013, Numerical simulation of tsunami waves generated by deformable submarine landslides, Ocean Modelling, v. 69, p. 146-165. doi:10.1016/j.ocemod.2013.07.001
Masson, D.G., Harbitz, C.B., Wynn, R.B., Pedersen, G., and Løvholt, F., 2006, Submarine landslides-Processes, triggers, and hazard prediction: Philosophical Transactions of the Royal Society A, v. 364, p. 2,009-2,039. doi:10.1098/ rsta.2006.1810

Mather, A.E., Hartley, A.J., and Griffiths, J.S., 2014, The giant coastal landslides of northern Chile-Tectonic and climate interactions on a classic convergent plate margin: Earth and Planetary Science Letters, v. 388, p. 249-256, doi:10.1016/j.epsl.2013.10.019

Miller, D.J., 1960, The Alaska earthquake of July 10, 1958Giant wave in Lituya Bay: Bulletin of the Seismological Society of America, v. 50, no. 2, p. 253-266.

Myers, E.P., and Baptista, A.M., 2001, Analysis of factors influencing simulations of the 1993 Hokkaido NanseiOki and 1964 Alaska tsunamis: Natural Hazards, v. 23, no. 1, p. 1-28.

Nadim, Farrokh, 2012, Risk assessment for earthquakeinduced submarine slides, in Yamada, Y., Kawamura, K., Ikehara, K., Ogawa, Y., Urgeles, R., Mosher, D., Chaytor, J., and Strasser, M., eds., Submarine mass movements and their consequences: Springer, Advances in Natural and Technological Hazards Research, v. 31, p. 15-27. doi:10.1007/978-94-007-2162-3_2

National Oceanic and Atmospheric Administration (NOAA), www.noaa.gov

National Oceanic and Atmospheric Administration (NOAA), National Center for Environmental Information (NCEI). https://www.ncei.noaa.gov/

National Geophysical Data Center/World Data Service (NGDC/WDS), 2015, Global Historical Tsunami Database (continually updated): NOAA National Geophysical Data Center. doi:10.7289/V5PN93H7

National Tsunami Hazard Mapping Program (NTHMP), 2010, Guidelines and best practices for tsunami inundation modeling for evacuation planning: NTHMP Mapping $\&$ Modeling Subcommittee, NOAA.

2012, Proceedings and Results of the 2011 NTHMP Model Benchmarking Workshop, Boulder: U.S. Department of Commerce/NOAA/NTHMP; (NOAA Special Report). 436 p. http://nthmp.tsunami.gov

Nicolsky, D.J., 2012, Alaska tsunami model, in Proceedings and Results of the 2011 NTHMP Model Benchmarking Workshop: Boulder, CO, U.S. Department of Commerce/NOAA/NTHMP, NOAA Special Report, p. 55-87. http://nthmp.tsunami.gov

Nicolsky, D.J., Suleimani, E.N., and Hansen, R.A., 2011, Validation and verification of a numerical model for tsunami propagation and runup: Pure and Applied Geophysics, v. 168 , p. $1,199-1,222$. doi:10.1007/s00024-010-0239

Nicolsky, D.J., Suleimani, E.N., and Hansen, R.A., 2012, Note on the 1964 Alaska tsunami generation by horizontal displacements of ocean bottom - Numerical modeling of the runup in Chenega Cove, Alaska: Pure and Applied Geophysics, published online. doi:10.1007/s00024012-0483-7

Nicolsky D.J., Suleimani, E.N., Haeussler, P.J., Ryan, H.F., Combellick, R.A., Koehler, R.D., and Hansen, R.A., 2013, 
Tsunami inundation maps of Port Valdez, Alaska: Alaska Division of Geological \& Geophysical Surveys Report of Investigations 2013-1, 79 p. doi:10.14509/25055

Nishenko, S.P., 1991, Circum-Pacific seismic potential, 1989-1999: Pure and Applied Geophysics, v. 135, p. 169-259.

Nishenko, S.P., and Jacob, K.H., 1990, Seismic potential of the Queen Charlotte-Alaska-Aleutian seismic zone: Journal of Geophysical Research, v. 95, no. B3, p. 2,511-2,532.

Okada, Yoshimitsu, 1985, Surface deformation due to shear and tensile faults in a half-space: Bulletin of the Seismological Society of America, v. 75, no. 4, p. 1,135-1,154.

Page, R.A., 1973, The Sitka, Alaska, earthquake of 1972: Earthquake Information Bulletin, v. 5, p. 4-9.

Pavlis, T.L., Picornell, Carlos, Serpa, L., Bruhn, R.L., and Plafker, George, 2004, Tectonic processes during oblique collision-Insights from the St. Elias orogen, northern North American Cordillera: Tectonics, v. 23, no. 3, TC3001, doi:10.1029/2003TC001557

Pavlis, T.A., Chapman, J.B., Bruhn, R.L., Ridgway, Kenneth, Worthington, L.L., Gulick, S.P.S., and Spotila, James, 2012, Structure of the actively deforming fold-thrust belt of the St. Elias orogen with implications for glacial exhumation and three-dimensional tectonic processes: Geosphere, v. 8, no. 5, p. 991-1,019. doi:10.1130/ GES00753.1

Plafker, George, 1967, Surface faults on Montague Island associated with the 1964 Alaska earthquake: U.S. Geological Survey Professional Paper 543-G, p. G1-G42. http://pubs.usgs.gov/pp/0543g/

Plafker, George, and Thatcher, Wayne, 2008, Geological and geophysical evaluation of the mechanisms of the great 1899 Yakutat Bay earthquakes, in Freymueller, J.T., Haeussler, P.J., Wesson, R.L., and Ekström, Göran, eds., Active tectonics and seismic potential of Alaska: Geophysical Monograph 179, p. 215-236. doi:10.1029/179GM12

Plafker, George, Kachadoorian, Reuben, Eckel, E.B., and Mayo, L.R., 1969, Effects of the earthquake of March 27, 1964, on various communities: U.S. Geological Survey Professional Paper 542-G, 50 p. http://pubs.usgs.gov/ $\mathrm{pp} / 0542 \mathrm{~g} /$

Rabinovich, A.B., Thomson, R.E., Bornhold, B.D., Fine, I.V., and Kulikov, E.A., 2003, Numerical modelling of tsunamis generated by hypothetical landslides in the Strait of Georgia, British Columbia: Pure and Applied Geophysics, v. 160 , no. 7, p. 1,273-1,313. doi:10.1007/ s000240300006

Ross, S.L., Jones, L.M., Wilson, R.I., Bahng, B., Borrero, J.C., Brosnan, D.M., Bwarie, J.T., Geist, E.L., Johnson, L.A., Hansen, R.A., Kirby, S.H., Knight, E., Knight, W.R., Long, K., Lynett, P.J., Miller, K.M., Mortensen, C.E., Nicolsky, D.J., Oglesby, D.D., Perry, S.C., Porter, K.A., Real, C.R., Ryan, K.J., Suleimani, E.N., Thio, H.K., Titov, V.V., Wein, A.M., Whitmore, P., and Wood, N.J., 2012, USGS SAFRR tsunami scenario-Potential impacts to the U.S. west coast from a plausible M 9 earthquake near the Alaska Peninsula [abst.]: American Geophysical
Union Fall Meeting, San Francisco, California, December 3-7, 2012.

Ryan, H.F., Lee, H.J., Haeussler, P.J., Alexander, C.R., and Kayen, R.E., 2010, Historic and paleo-submarine landslide deposits imaged beneath Port Valdez, AlaskaImplications for tsunami generation in a glacial fjord, in Submarine mass movements and their consequences: Advances in natural and technological hazards research, v. 28, p. 411-421. doi:10.1007/978-90-481-3071-9_34

Shao, Guangfu, Li, Xiangyu, Ji, Chen, and Maeda, Takahiro, 2011, Focal mechanism and slip history of $2011 \mathrm{M}_{\mathrm{W}} 9.1$ off the Pacific coast of Tohoku earthquake, constrained with teleseismic body and surface waves: Earth Planets and Space, v. 63, no. 7, p. 559-564. doi:10.5047/ eps.2011.06.028

Shennan, Ian, Barlow, Natasha, and Combellick, R.A., 2008, Paleoseismological records of multiple great earthquakes in south-central Alaska-A 4,000 year record at Girdwood, in Freymueller, J.T., Haeussler, P.J., Wesson, R.L, and Ekström, G., eds., Active Tectonics and Seismic Potential of Alaska: American Geophysical Union Geophysical Monograph 179, p. 185-199.

Shennan, Ian, Bruhn, Ronald, and Plafker, George, 2009, Multi-segment earthquakes and tsunami potential of the Aleutian megathrust: Quaternary Science Reviews, v. 28, no. 1-2, p. 7-13. doi:10.1016/j.quascirev.2008.09.016

Shennan, Ian, Bruhn, Ronald, Barlow, Natasha, Good, Kelly, and Hocking, Emma, 2014, Late Holocene great earthquakes in the eastern part of the Aleutian megathrust: Quaternary Science Reviews, v. 84, p. 86-97. doi:10.1016/j.quascirev.2013.11.010

Suito, Hisashi, and Freymueller, J.T., 2009, A viscoelastic and afterslip postseismic deformation model for the 1964 Alaska earthquake: Journal of Geophysical Research, v. 114, no. B11, p. 404-426. doi:10.1029/2008JB005954

Suleimani, E.N., 2011, Numerical studies of tectonic and landslide-generated tsunamis caused by the 1964 Great Alaska Earthquake: Fairbanks, Alaska, University of Alaska Fairbanks, Ph.D. dissertation, 181 p.

Suleimani, E.N., Hansen, R.A., and Haeussler, P.J., 2009, Numerical study of tsunami generated by multiple submarine slope failures in Resurrection Bay, Alaska, during the M 9.2 1964 earthquake: Pure and Applied Geophysics, v. 166, no. 1, p. 131-152. doi:10.1007/s00024-004-0430-3

Suleimani, E.N., Nicolsky, D.J., Haeussler, P.J., and Hansen, R.A., 2011, Combined effects of tectonic and landslidegenerated tsunami runup at Seward, Alaska, during the $\mathrm{M}_{\mathrm{w}} 9.21964$ earthquake: Pure and Applied Geophysics, v. 168 , no. 6 , p. $1,053-1,074$. doi:10.1007/s00024-0100228-4

Suleimani, E.N., Nicolsky, D.J., and Koehler, R.D., 2013, Tsunami inundation maps of Sitka, Alaska: Alaska Division of Geological \& Geophysical Surveys Report of Investigation 2013-3, 76 p., 1 sheet, scale 1:250,000. doi:10.14509/26671

Suleimani, E.N., Nicolsky, D.J., West, D.A., Combellick, R.A., and Hansen, R.A., 2010, Tsunami inundation maps of Seward and northern Resurrection Bay, Alaska: Alaska 
Division of Geological \& Geophysical Surveys Report of Investigation 2010-1, 47 p., 3 sheets, scale 1:63,360. doi:10.14509/21001

Swartz, J.M., Gulick, S.P.S., and Goff, J.A., 2015, Gulf of Alaska continental slope morphology-Evidence for recent trough mouth fan formation: Geochemistry, Geophysics, Geosystems, v. 16, no. 1, p. 165-177. doi:10.1002/2014GC005594

Sykes, L.R., 1971, Aftershock zones of great earthquakes, seismicity gaps, and earthquake prediction for Alaska and the Aleutians: Journal of Geophysical Research, v. 76 , no. 32, p. 8,021-8,041.

Synolakis, C.E., and Bernard, E.N., 2006, Tsunami science before and beyond Boxing Day 2004, in Thompson, J.M.T., Heppert, H.E., and Sparks, R.S.J., eds., Extreme Natural Hazards: Philosophical Transactions of the Royal Society (Mathematical, Physical, and Engineering Sciences), v. 364 , no. 1,845 , p. 2,231-2,265. doi:10.1098/ rsta.2006.1824

Synolakis, C.E., Bernard, E.N., Titov, V.V., Kânoğlu, U., and González, F.I., 2007, Standards, criteria, and procedures for NOAA evaluation of tsunami numerical models: Seattle, Washington, NOAA/Pacific Marine Environmental Laboratory, Technical Memorandum OAR PMEL-135, $55 \mathrm{p}$.

Tang, Liujuan, Titov, V.V., Bernard, E.N., Wei, Yong, Chamberlin, C.D., Newman, J.C., Mofjeld, H.O., Arcas, Diego, Eble, M.C., Moore, Christopher, Uslu, Burak, Pells, Clint, Spillane, Michael, Wright, Lindsey, and Gica, Edison, 2012, Direct energy estimation of the 2011 Japan tsunami using deep-ocean pressure measurements: Journal of Geophysical Research, v. 117, no. C8. doi:10.1029/2011JC007635

Tarr, R.S., and Martin, Lawrence, 1912, The earthquakes at Yakutat Bay, Alaska, in September 1899, with a preface by G.K. Gilbert: U.S. Geological Survey Professional Paper 69, 135 p., 3 sheets, scale 1:5,000,000.

Tehranirad, Babak, Kirby, J.T., Ma, Gangfeng. and Shi, Fengyan, 2012, Tsunami benchmark results for nonhydrostatic wave model NHWAVE, Version 1.1: Newark, New Jersey, University of Delaware Center for Applied Coastal Research, Research Report No. CACR-12-03, $43 \mathrm{p}$.

Thomson, R.E., Rabinovich, A.B., Kulikov, E.A., Fine, I.V., and Bornhold, B.D., 2001, On numerical simulation of the landslide-generated tsunami of November 3, 1994, in Skagway Harbor, Alaska, in Hebenstreit, G.T., ed., Tsunami research at the end of a critical decade:
Springer-Verlag, Advances in Natural and Technological Hazards Research, v. 18, p. 243-282. doi:10.1007/97894-017-3618-3_17

Titov, V.V., and Synolakis, C.E., 1995, Modeling of breaking and nonbreaking long-wave evolution and runup using VTCS-2: Journal of Waterway, Port, Coastal, and Ocean Engineering, v. 121, no. 6, p. 308-316. doi:10.1061/ (ASCE)0733-950X(1995)121:6(308)

1997, Extreme inundation flows during the Hokkaido-Nansei-Oki tsunami: Geophysical Research Letters, v. 24, no. 11, p, 1,315-1,318. doi:10.1029/97GL01128

Tocher, Don, 1960, The Alaska earthquake of July 10, 1958Movement on the Fairweather fault and field investigation of southern epicentral region: Bulletin of the Seismological Society of America, v. 50, no. 2, p. 267-292.

Wesson, R.L., Boyd, O.S., Mueller, C.S., Bufe, C.G., Frankel, A.D., and Petersen, M.D., 2007, Revision of time-independent probabilistic seismic hazard maps for Alaska: U.S. Geological Survey Open-File Report 2007-1043, 33 p.

Wilson, B.W., and Tørum, A., 1968, The tsunami of the Alaskan earthquake, 1964-Engineering evaluation: U.S. Army Corps of Engineers, Technical Memorandum No. 25, 401 p.

Worthington, L.L., Gulick, S.P.S., and Pavlis, T.L., 2008, Identifying active structures in the Kayak Island and Pamplona zones-Implications for offshore tectonics of the Yakutat Microplate, Gulf of Alaska, in Freymueller, J.T., Haeussler, P.J., Wesson, R.L., and Ekström, Göran, eds., Active tectonics and seismic potential of Alaska: American Geophysical Union Geophysical Monograph Series, v. 179, p. 257-268. doi:10.1029/179GM14

Worthington, L.L., Gulick, S.P.S., and Pavlis, T.L., 2010, Coupled stratigraphic and structural evolution of a glaciated orogenic wedge, offshore St. Elias orogen, Alaska: Tectonics, v. 29, no. 6, TC6013. doi:10.1029/2010TC002723 Worthington, L.L., Van Avendonk, H.J.A., Gulick, S.P.S., Christeson, G.L., and Pavlis, T.L., 2012, Crustal structure of the Yakutat terrane and the evolution of subduction and collision in southern Alaska: Journal of Geophysical Research, v. 117, no. B1, B01102. doi:10.1029/2011JB008493

Yehle, L.A., 1979, Reconnaissance engineering geology of the Yakutat area, Alaska, with emphasis on evaluation of earthquake and other geologic hazards: U.S. Geological Survey Professional Paper 1074, 44 p., 1 sheet, scale $1: 63,360$. 


\section{APPENDIX A}

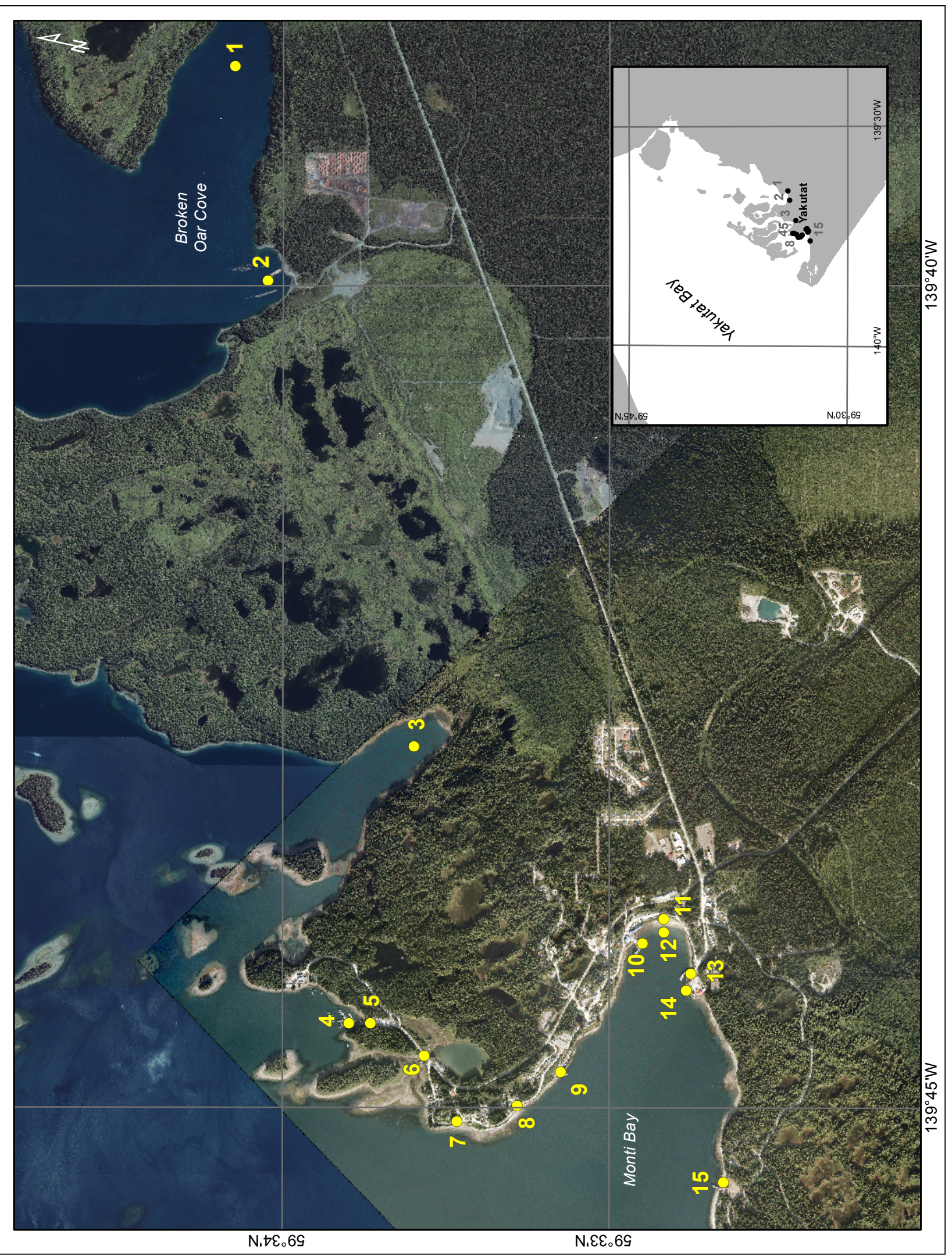

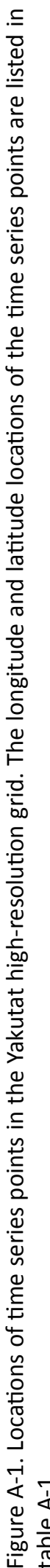




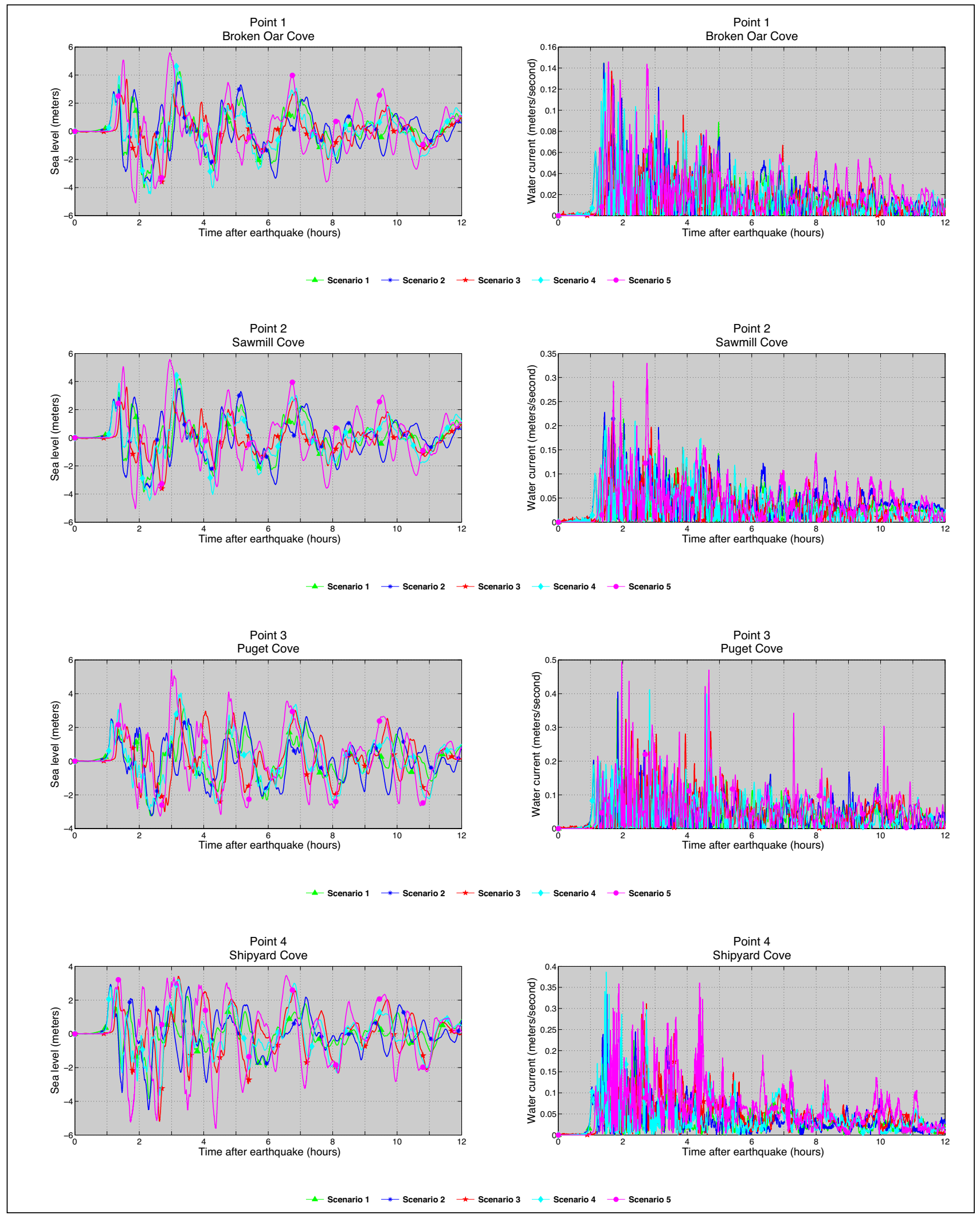

Figure A-2. Time series of the water level (left column) and velocity (right column) at Yakutat for scenarios 1-5 at the locations shown in figure A-1. Elevations of onshore locations and the ocean depth at offshore locations are given based on the pre-earthquake MHHW datum. The maximum water level for the above scenarios are listed in table A-2, and values for maximum velocity are listed in table A-3. 


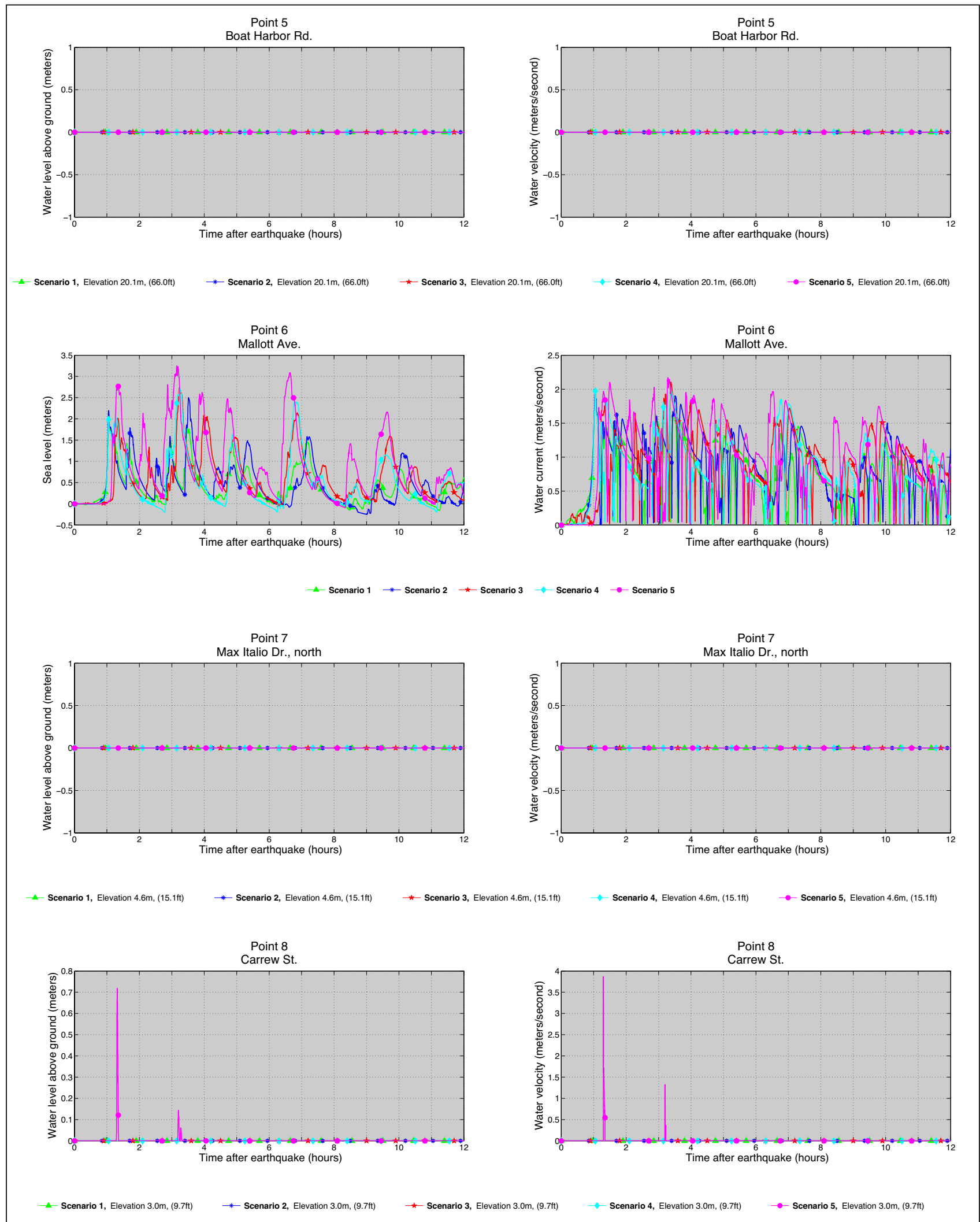

Figure A-2 (continued). Time series of the water level (left column) and velocity (right column) at Yakutat for scenarios 1-5 at the locations shown in figure A-1. Elevations of onshore locations and the ocean depth at offshore locations are given based on the pre-earthquake MHHW datum. The maximum water level for the above scenarios are listed in table A-2, and values for maximum velocity are listed in table A-3. 


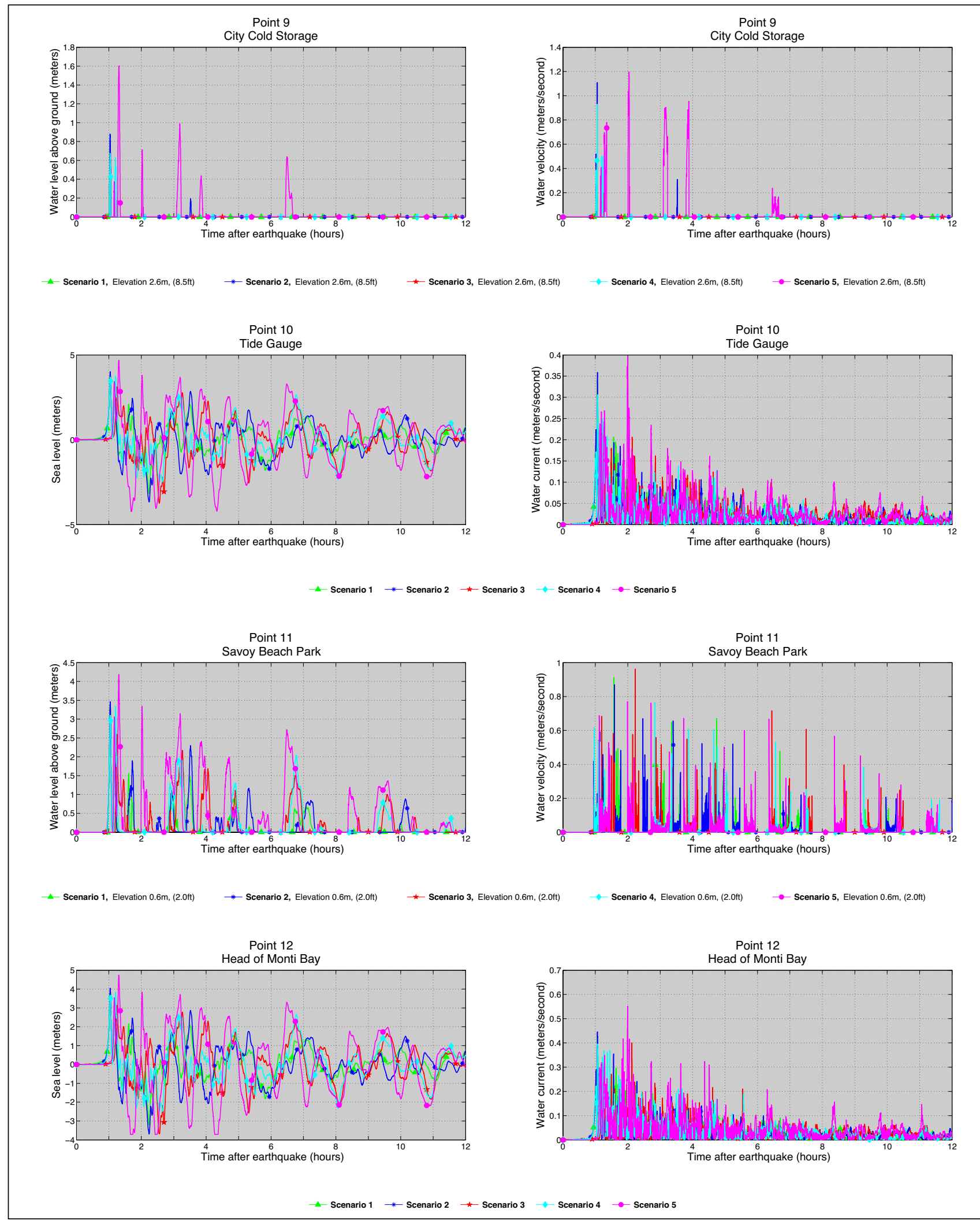

Figure A-2 (continued). Time series of the water level (left column) and velocity (right column) at Yakutat for scenarios 1-5 at the locations shown in figure A-1. Elevations of onshore locations and the ocean depth at offshore locations are given based on the pre-earthquake MHHW datum. The maximum water level for the above scenarios are listed in table A-2, and values for maximum velocity are listed in table A-3. 


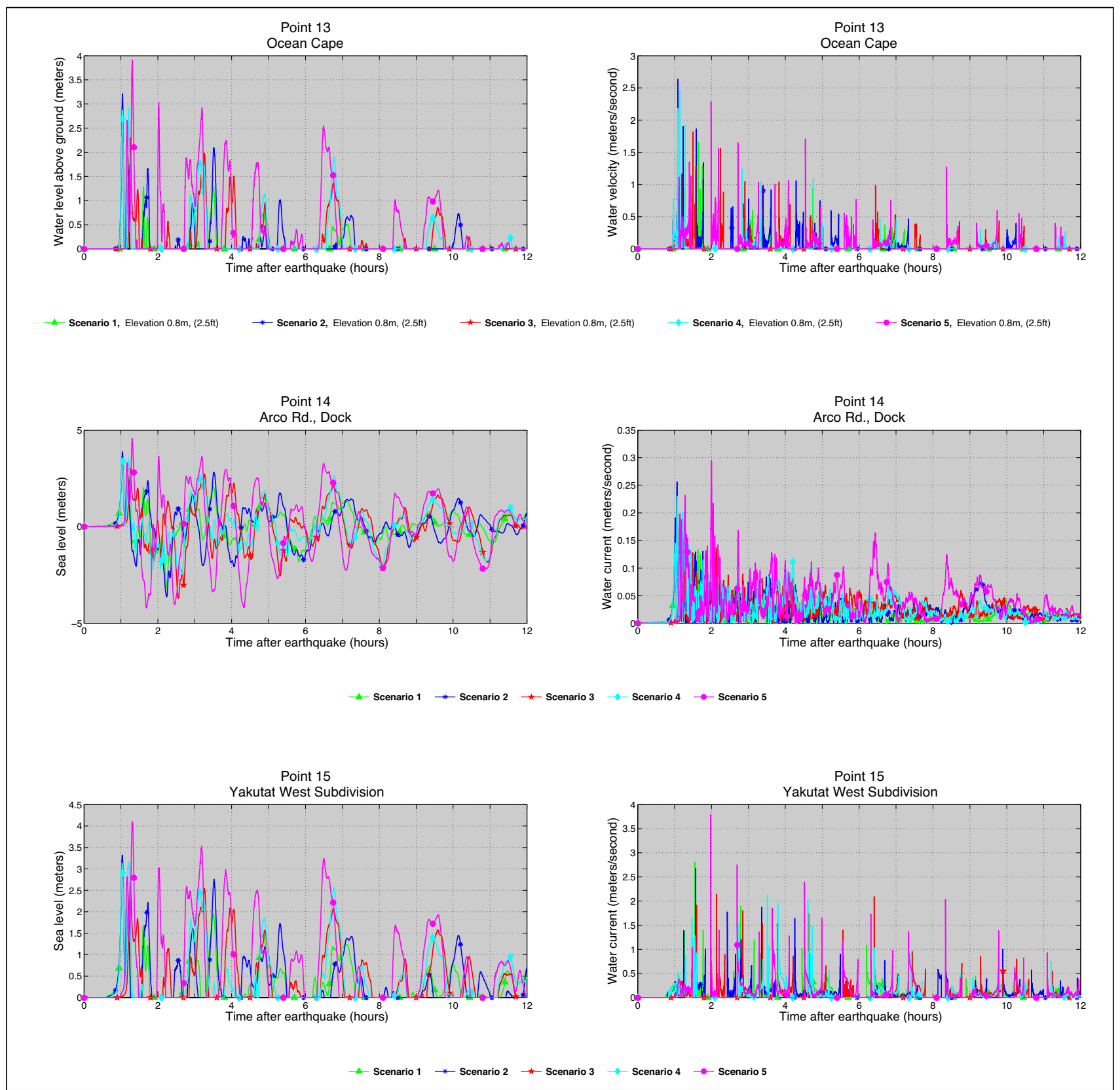

Figure A-2 (continued). Time series of the water level (left column) and velocity (right column) at Yakutat for scenarios 1-5 at the locations shown in figure A-1. Elevations of onshore locations and the ocean depth at offshore locations are given based on the pre-earthquake MHHW datum. The maximum water level for the above scenarios are listed in table A-2, and values for maximum velocity are listed in table A-3. 


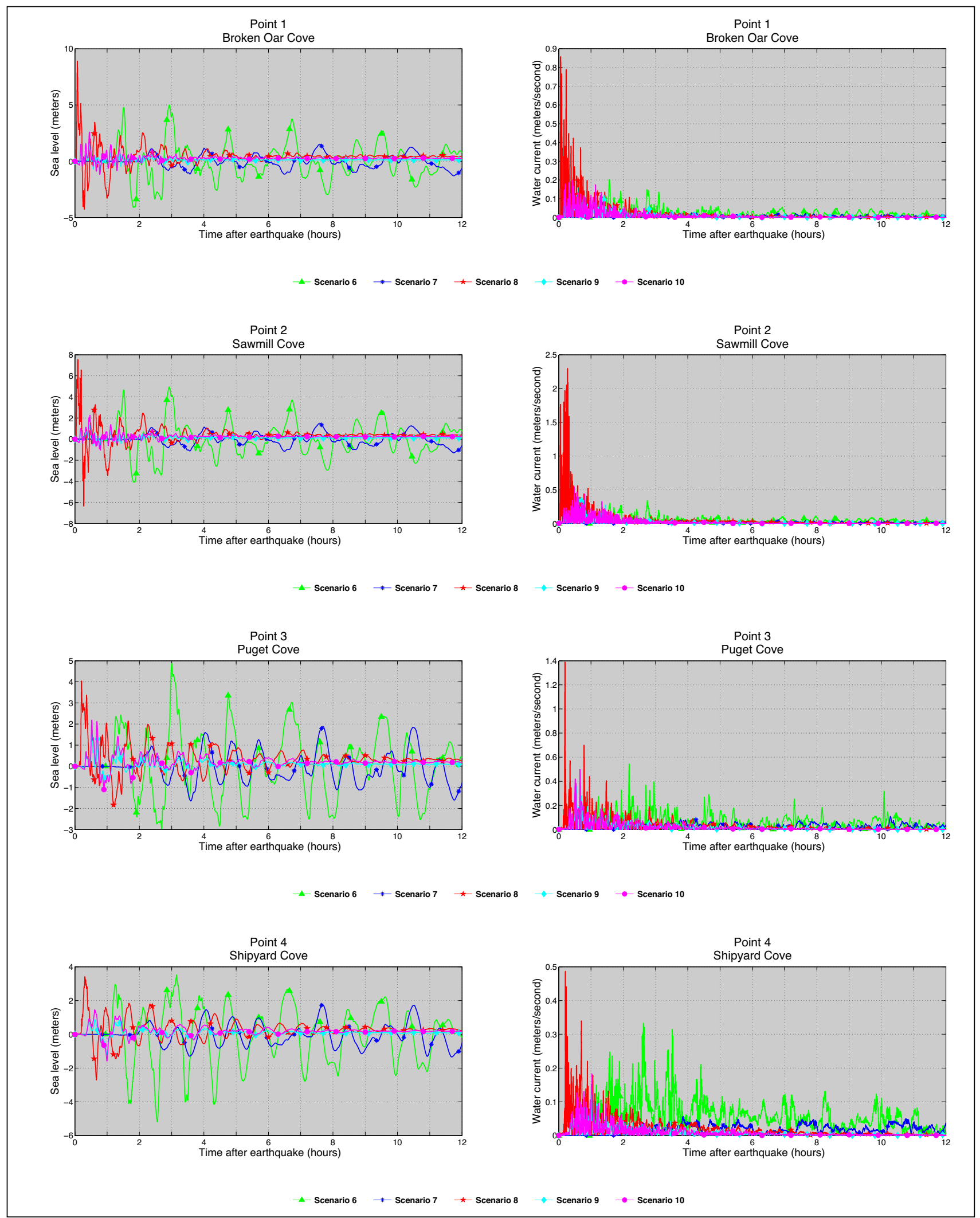

Figure A-3. Time series of the water level (left column) and velocity (right column) at Yakutat for scenarios 6-10 at the locations shown in figure A-1. Elevations of onshore locations and the ocean depth at offshore locations are given based on the pre-earthquake $\mathrm{MHHW}$ datum. The maximum water level for the above scenarios are listed in table A-2, and values for maximum velocity are listed in table A-3. 


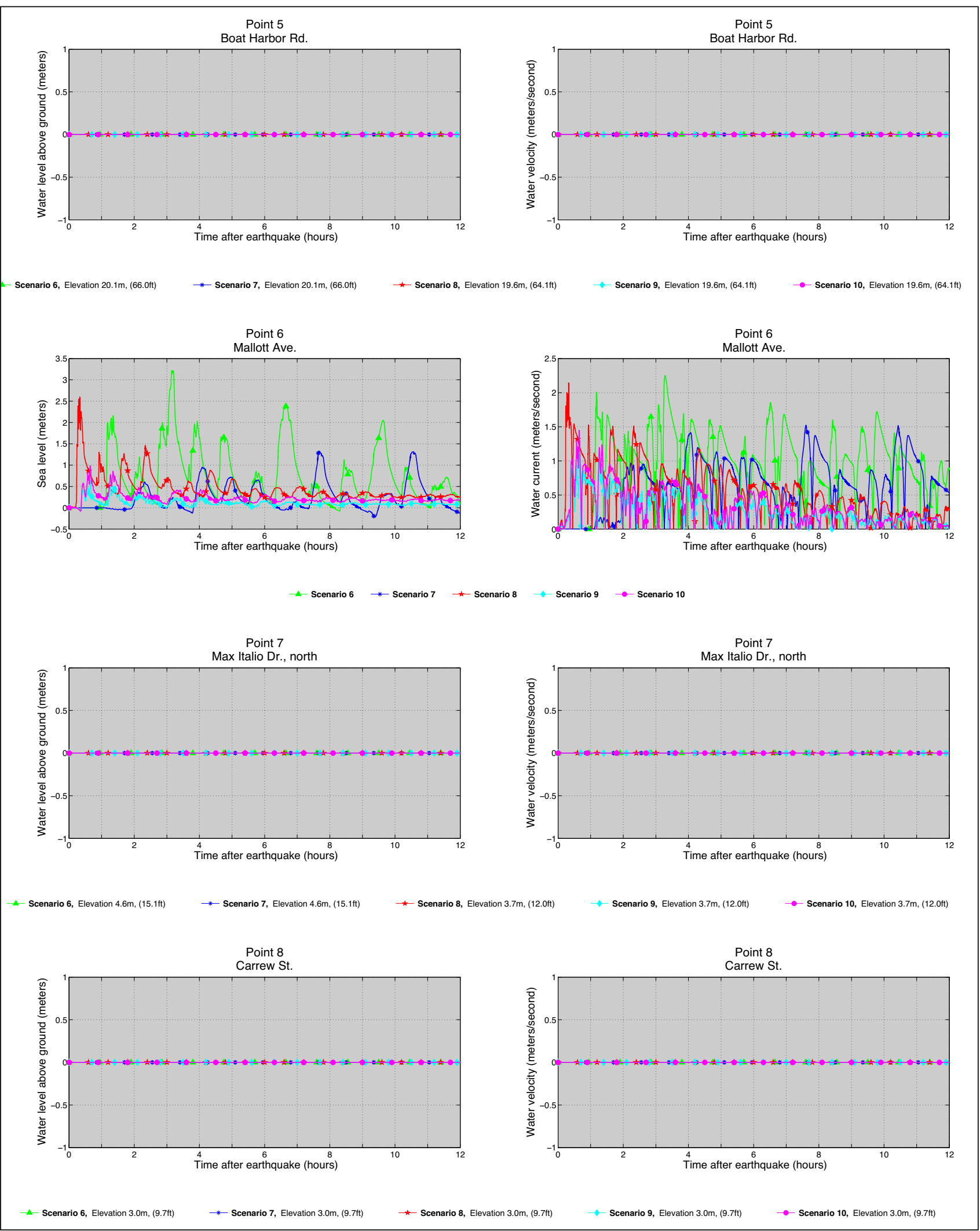

Figure A-3 (continued). Time series of the water level (left column) and velocity (right column) at Yakutat for scenarios 6-10 at the locations shown in figure A-1. Elevations of onshore locations and the ocean depth at offshore locations are given based on the pre-earthquake MHHW datum. The maximum water level for the above scenarios are listed in table A-2, and values for maximum velocity are listed in table A-3. 


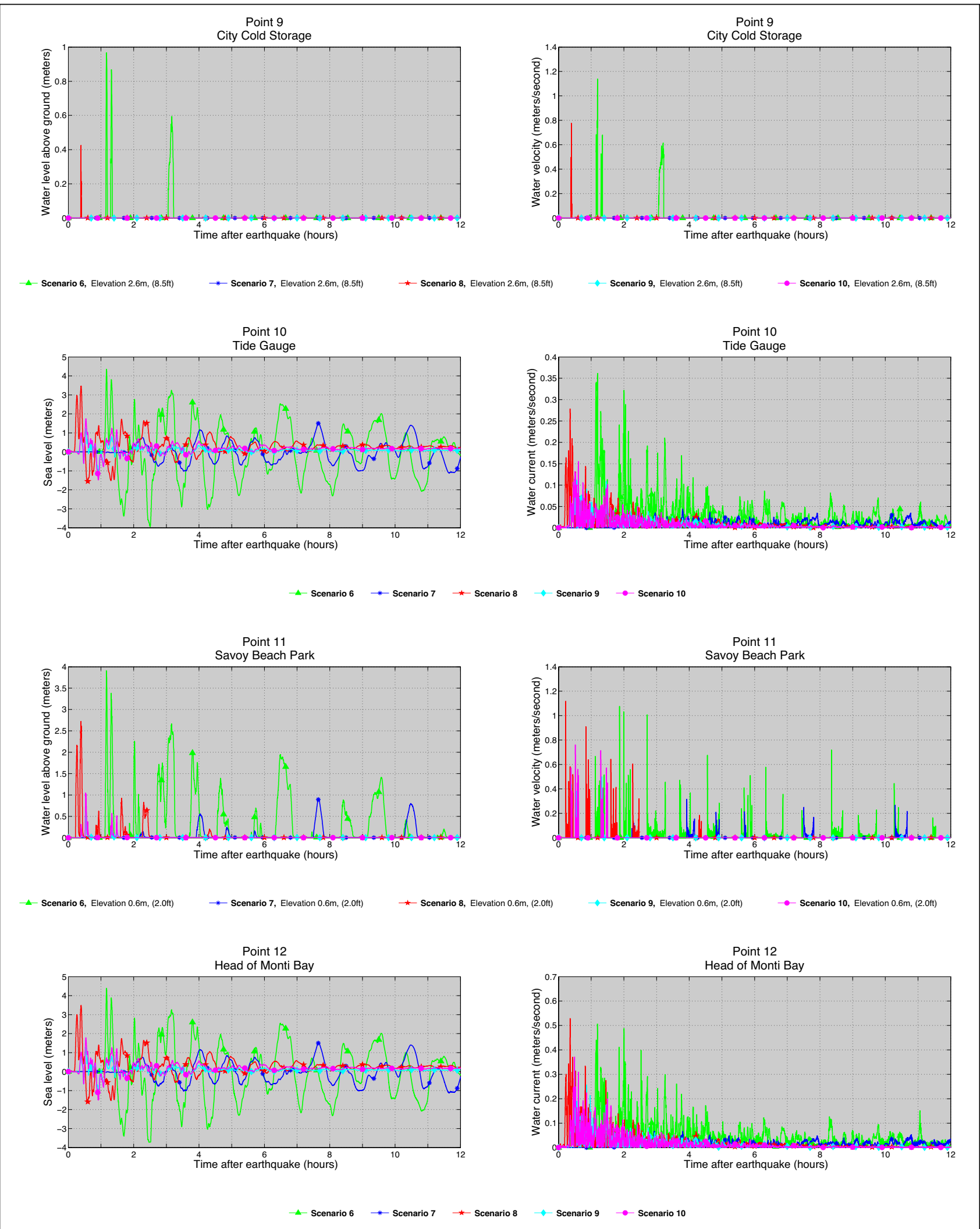

Figure A-3 (continued). Time series of the water level (left column) and velocity (right column) at Yakutat for scenarios 6-10 at the locations shown in figure A-1. Elevations of onshore locations and the ocean depth at offshore locations are given based on the pre-earthquake MHHW datum. The maximum water level for the above scenarios are listed in table A-2, and values for maximum velocity are listed in table A-3. 


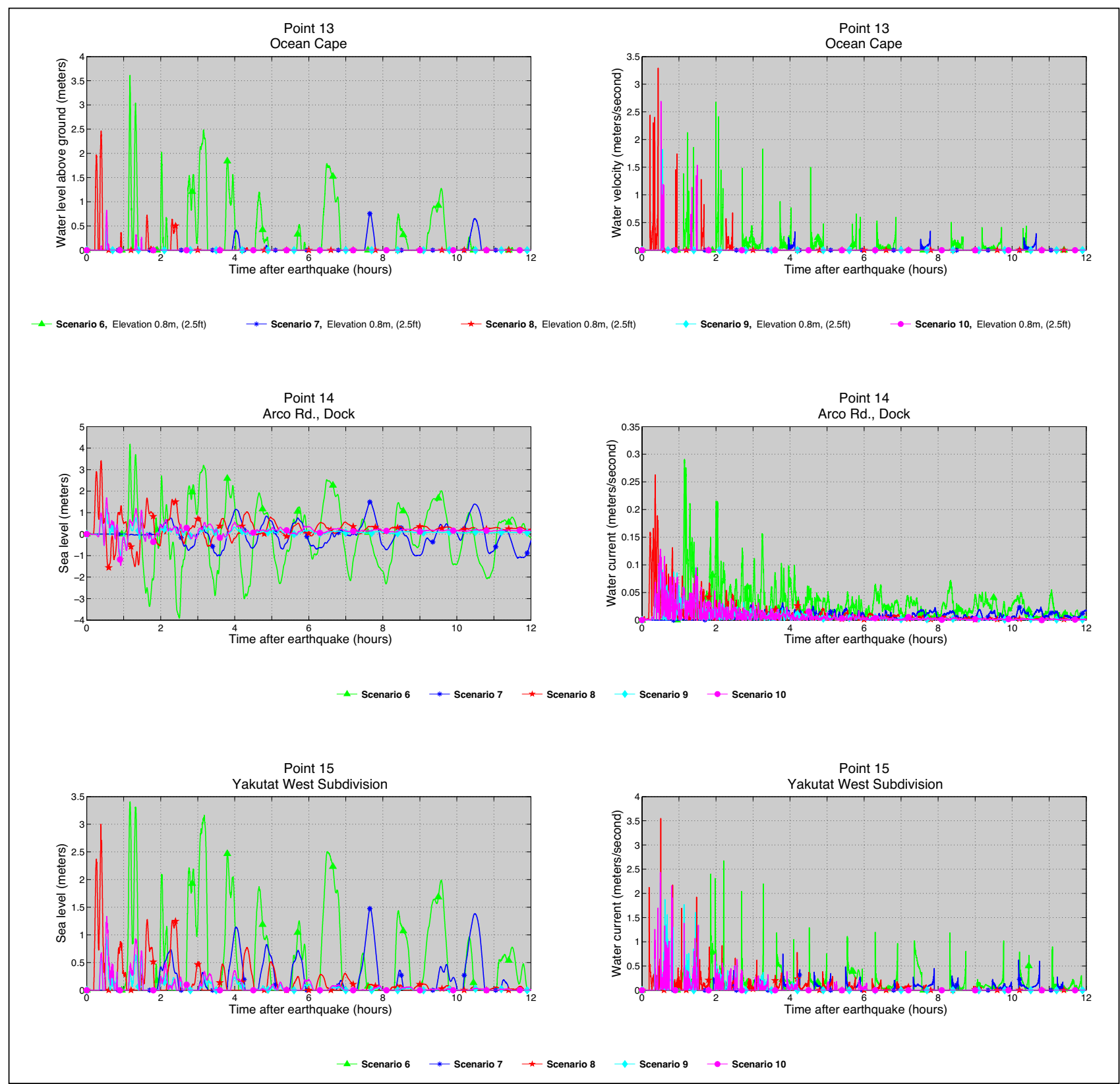

Figure A-3 (continued). Time series of the water level (left column) and velocity (right column) at Yakutat for scenarios 6-10 at the locations shown in figure A-1. Elevations of onshore locations and the ocean depth at offshore locations are given based on the pre-earthquake MHHW datum. The maximum water level for the above scenarios are listed in table A-2, and values for maximum velocity are listed in table A-3. 
Table A-1. The longitude and latitude locations of the time series points. WGS84 datum.

\begin{tabular}{|c|c|c|c|l|}
\hline Point & $\begin{array}{c}\text { Longitude } \\
\left({ }^{\mathbf{}} \mathbf{W}\right)\end{array}$ & $\begin{array}{c}\text { Latitude } \\
\left({ }^{\mathbf{}} \mathbf{N}\right)\end{array}$ & $\begin{array}{c}\text { Point location } \\
(\text { Water or Land) }\end{array}$ & \multicolumn{1}{|c|}{$\begin{array}{c}\text { Name of the time series } \\
\text { point }\end{array}$} \\
\hline 1 & 139.644444 & 59.569167 & W & Broken Oar Cove \\
\hline 2 & 139.666111 & 59.567500 & W & Sawmill Cove \\
\hline 3 & 139.713333 & 59.560000 & W & Puget Cove \\
\hline 4 & 139.741389 & 59.563333 & W & Shipyard Cove \\
\hline 5 & 139.741389 & 59.562222 & L & Boat Harbor Rd. \\
\hline 6 & 139.744722 & 59.559444 & L & Mallott Ave. \\
\hline 7 & 139.751389 & 59.557778 & L & Max Italio Dr. north \\
\hline 8 & 139.749722 & 59.554722 & L & Carrew St. \\
\hline 9 & 139.746389 & 59.552500 & L & City Cold Storage \\
\hline 10 & 139.733333 & 59.548333 & W & Tide Gauge \\
\hline 11 & 139.730833 & 59.547222 & L & Savoy Beach Park \\
\hline 12 & 139.732222 & 59.547222 & W & Head of Monti Bay \\
\hline 13 & 139.736389 & 59.545833 & L & Ocean Cape \\
\hline 14 & 139.738056 & 59.546111 & W & Arco Rd. Dock \\
\hline 15 & 139.757500 & 59.544167 & L & Yakutat West Subdivision \\
\hline
\end{tabular}

Table A-2. Calculated maximum sea level for all tectonic scenarios at locations listed in table A-1. The maximum water level above ground is provided for onshore (land) locations (L), whereas the maximum water level above the pre-earthquake $\mathrm{MHHW}$ is provided for offshore (water) locations (W).

\begin{tabular}{|c|c|c|c|c|c|c|c|c|c|c|c|c|c|}
\hline \multirow{3}{*}{ Point } & \multirow{3}{*}{$\begin{array}{l}\text { Water } \\
\text { or } \\
\text { Land }\end{array}$} & \multirow{3}{*}{$\begin{array}{l}\text { Longitude } \\
\qquad\left({ }^{\circ} \mathrm{W}\right)\end{array}$} & \multirow{3}{*}{$\begin{array}{l}\text { Latitude } \\
\qquad\left({ }^{\circ} \mathrm{N}\right)\end{array}$} & \multicolumn{10}{|c|}{ Maximum water level above ground/sea level (meters) } \\
\hline & & & & \multicolumn{10}{|c|}{ Scenarios } \\
\hline & & & & 1 & 2 & 3 & 4 & 5 & 6 & 7 & 8 & 9 & 10 \\
\hline 1 & W & 139.644444 & 59.569167 & 4.3 & 3.6 & 3.7 & 4.7 & 5.6 & 5.0 & 1.5 & 8.9 & 1.6 & 2.6 \\
\hline 2 & W & 139.666111 & 59.567500 & 4.2 & 3.5 & 3.6 & 4.6 & 5.6 & 5.0 & 1.5 & 7.5 & 1.3 & 2.3 \\
\hline 3 & W & 139.713333 & 59.560000 & 3.1 & 2.9 & 3.7 & 4.0 & 5.4 & 4.9 & 1.9 & 4.0 & 1.5 & 2.2 \\
\hline 4 & $w$ & 139.741389 & 59.563333 & 2.9 & 2.9 & 3.4 & 3.2 & 3.5 & 3.5 & 1.8 & 3.4 & 0.9 & 1.4 \\
\hline 5 & $L$ & 139.741389 & 59.562222 & 0.0 & 0.0 & 0.0 & 0.0 & 0.0 & 0.0 & 0.0 & 0.0 & 0.0 & 0.0 \\
\hline 6 & $\mathrm{~L}$ & 139.744722 & 59.559444 & 2.1 & 2.5 & 2.7 & 2.8 & 3.3 & 3.2 & 1.3 & 2.6 & 0.6 & 1.0 \\
\hline 7 & $L$ & 139.751389 & 59.557778 & 0.0 & 0.0 & 0.0 & 0.0 & 0.0 & 0.0 & 0.0 & 0.0 & 0.0 & 0.0 \\
\hline 8 & $\mathrm{~L}$ & 139.749722 & 59.554722 & 0.0 & 0.0 & 0.0 & 0.0 & 0.7 & 0.0 & 0.0 & 0.0 & 0.0 & 0.0 \\
\hline 9 & $\mathrm{~L}$ & 139.746389 & 59.552500 & 0.8 & 0.9 & 0.2 & 0.7 & 1.6 & 1.0 & 0.0 & 0.4 & 0.0 & 0.0 \\
\hline 10 & $W$ & 139.733333 & 59.548333 & 3.9 & 4.0 & 3.1 & 3.7 & 4.7 & 4.4 & 1.5 & 3.5 & 1.2 & 1.7 \\
\hline 11 & $\mathrm{~L}$ & 139.730833 & 59.547222 & 3.3 & 3.5 & 2.6 & 3.3 & 4.2 & 3.9 & 0.9 & 2.7 & 0.6 & 1.0 \\
\hline 12 & W & 139.732222 & 59.547222 & 3.9 & 4.0 & 3.1 & 3.8 & 4.7 & 4.4 & 1.5 & 3.5 & 1.3 & 1.8 \\
\hline 13 & $\mathrm{~L}$ & 139.736389 & 59.545833 & 3.1 & 3.2 & 2.3 & 2.9 & 3.9 & 3.6 & 0.8 & 2.5 & 0.4 & 0.8 \\
\hline 14 & W & 139.738056 & 59.546111 & 3.8 & 3.9 & 3.0 & 3.6 & 4.6 & 4.2 & 1.5 & 3.4 & 1.2 & 1.7 \\
\hline 15 & $L$ & 139.757500 & 59.544167 & 3.2 & 3.3 & 2.7 & 3.2 & 4.1 & 3.4 & 1.5 & 3.0 & 1.0 & 1.3 \\
\hline
\end{tabular}


Table A-3. Calculated maximum water current velocities for all tectonic scenarios at locations listed in table A-1. The onshore (land) locations are indicated by L, whereas the offshore (water) locations are marked by W.

\begin{tabular}{|c|c|c|c|c|c|c|c|c|c|c|c|c|c|}
\hline \multirow{3}{*}{ Point } & \multirow{3}{*}{$\begin{array}{l}\text { Water } \\
\text { or } \\
\text { Land }\end{array}$} & \multirow{3}{*}{$\begin{array}{l}\text { Longitude } \\
\quad\left({ }^{\circ} \mathrm{W}\right)\end{array}$} & \multirow{3}{*}{$\begin{array}{l}\text { Latitude } \\
\qquad\left({ }^{\circ} \mathrm{N}\right)\end{array}$} & \multicolumn{10}{|c|}{ Maximum water velocity (meters/second) } \\
\hline & & & & \multicolumn{10}{|c|}{ Scenarios } \\
\hline & & & & 1 & 2 & 3 & 4 & 5 & 6 & 7 & 8 & 9 & 10 \\
\hline 1 & W & 139.644444 & 59.569167 & 0.1 & 0.1 & 0.1 & 0.1 & 0.1 & 0.2 & 0.0 & 0.9 & 0.2 & 0.2 \\
\hline 2 & $\mathrm{~W}$ & 139.666111 & 59.567500 & 0.2 & 0.2 & 0.2 & 0.2 & 0.3 & 0.3 & 0.0 & 2.3 & 0.4 & 0.5 \\
\hline 3 & W & 139.713333 & 59.560000 & 0.4 & 0.4 & 0.3 & 0.4 & 0.5 & 0.5 & 0.1 & 1.4 & 0.4 & 0.5 \\
\hline 4 & $\mathrm{~W}$ & 139.741389 & 59.563333 & 0.2 & 0.3 & 0.3 & 0.4 & 0.4 & 0.3 & 0.1 & 0.5 & 0.1 & 0.2 \\
\hline 5 & $L$ & 139.741389 & 59.562222 & 0.0 & 0.0 & 0.0 & 0.0 & 0.0 & 0.0 & 0.0 & 0.0 & 0.0 & 0.0 \\
\hline 6 & $\mathrm{~L}$ & 139.744722 & 59.559444 & 2.0 & 2.0 & 2.1 & 2.0 & 2.2 & 2.2 & 1.5 & 2.1 & 1.1 & 1.4 \\
\hline 7 & $\mathrm{~L}$ & 139.751389 & 59.557778 & 0.0 & 0.0 & 0.0 & 0.0 & 0.0 & 0.0 & 0.0 & 0.0 & 0.0 & 0.0 \\
\hline 8 & $L$ & 139.749722 & 59.554722 & 0.0 & 0.0 & 0.0 & 0.0 & 3.9 & 0.0 & 0.0 & 0.0 & 0.0 & 0.0 \\
\hline 9 & $\mathrm{~L}$ & 139.746389 & 59.552500 & 1.1 & 1.1 & 0.2 & 0.9 & 1.2 & 1.1 & 0.0 & 0.8 & 0.0 & 0.0 \\
\hline 10 & $\mathrm{~W}$ & 139.733333 & 59.548333 & 0.3 & 0.4 & 0.2 & 0.3 & 0.4 & 0.4 & 0.0 & 0.3 & 0.1 & 0.2 \\
\hline 11 & $L$ & 139.730833 & 59.547222 & 0.9 & 0.9 & 1.0 & 0.8 & 0.8 & 1.1 & 0.3 & 1.1 & 0.5 & 0.8 \\
\hline 12 & W & 139.732222 & 59.547222 & 0.4 & 0.4 & 0.4 & 0.4 & 0.6 & 0.5 & 0.1 & 0.5 & 0.3 & 0.4 \\
\hline 13 & $\mathrm{~L}$ & 139.736389 & 59.545833 & 2.6 & 2.6 & 1.8 & 2.5 & 2.3 & 2.7 & 0.3 & 3.3 & 1.8 & 2.7 \\
\hline 14 & W & 139.738056 & 59.546111 & 0.2 & 0.3 & 0.1 & 0.2 & 0.3 & 0.3 & 0.0 & 0.3 & 0.1 & 0.1 \\
\hline 15 & $\mathrm{~L}$ & 139.757500 & 59.544167 & 2.8 & 2.7 & 2.1 & 2.1 & 3.8 & 2.7 & 0.7 & 3.5 & 2.2 & 2.4 \\
\hline
\end{tabular}

